MARISA AGUETONI FONTES

\title{
CONCEPÇÕES DE PSICOPEDAGOGIA NO BRASIL: REFLEXÕES A PARTIR DA TEORIA CRÍTICA DA SOCIEDADE
}




\title{
CONCEPÇÕES DE PSICOPEDAGOGIA NO BRASIL: REFLEXÕES A PARTIR DA TEORIA CRÍTICA DA SOCIEDADE
}

\author{
Dissertação apresentada ao Instituto de Psicologia \\ da Universidade de São Paulo, como parte dos requisitos \\ para obtenção do título de Mestre em Psicologia
}

Área de Concentração: Psicologia Escolar e do Desenvolvimento Humano

Orientador: Prof. Dr. José Leon Crochik

São Paulo

fevereiro - 2005 
Ficha Catalográfica preparada pelo Serviço de Biblioteca e Documentação do Instituto de Psicologia da USP

Fontes, M. A.

Concepções de psicopedagogia no Brasil: reflexões a partir da teoria crítica da sociedade./ Marisa Aguetoni Fontes. - São Paulo: s.n., 2005. $-224 p$.

Dissertação (mestrado) - Instituto de Psicologia da Universidade de São Paulo. Departamento de Psicologia da Aprendizagem, do Desenvolvimento e da Personalidade.

Orientadora: José Leon Crochik.

1. Psicopedagogia 2. Teoria crítica 3. Psicologia educacional 4. Pesquisa científica I. Título. 


\section{Errata}

Página

3 (11 $\left.1^{\text {linha }}\right)$

8 (1 1 linha)

8

(último os resultados colhidos

parágrafo)

25 (última linha) maior ênfase na Educação Infantil, pois é na primeira infância

Onde se lê

objetivos bem claros:

preocupar com

Referentes

Leia-se

objetivos bem claros: voltar-se para os problemas

referente

os resultados da análise dos textos colhidos

maior ênfase na Educação Infantil, com necessidade de esclarecimento da comunidade $e$ crítica imanente, pois é na primeira infância

38 (18 $8^{\mathrm{a}}$ linha) Seu projeto não foi aceito pela comunidade científica da época.

Seu projeto não foi aceito pela comunidade científica da época porque não se acreditava que seria rentável educar crianças internadas.

$77\left(1^{\text {a }}\right.$ linha $)$

Este capítulo tem como objetivos apresentar os resultados obtidos na pesquisa com o CD... e com as dissertações

Este capítulo tem como objetivo apresentar os resultados da análise dos textos obtidos na pesquisa do $\mathrm{CD}$... e das dissertações

\section{9 (6 $6^{\mathrm{a}}$ linha)}

educação conteudística, mais uma educação mais voltada para a preocupada em informar do que informação do que formação formar

à Psicopedagogia

(antepenúltima linha) 150 ( $7^{a}$ linha)

Mas ao fazer isso 


\section{CONCEPÇÕES DE PSICOPEDAGOGIA NO BRASIL: REFLEXÕES A PARTIR DA TEORIA CRÍTICA DA SOCIEDADE}

MARISA AGUETONI FONTES

\section{Banca Examinadora:}

Prof. Dra. Maria Cecília Cortez Christiano de Souza

Prof. Dra. Maria Helena Souza Patto

Prof. Dr. José Leon Crochik (orientador)

Dissertação defendida e aprovada em: 
Aos meus PAIS, por me darem condições para concluir mais esta etapa nos meus estudos.

\section{CHERRI,} companheiro e "co-autor felino", que infelizmente a doença não permitiu que estivesse entre nós na conclusão desse trabalho. 
Agradecimentos 
"Lembrar é fácil para quem tem memória, esquecer é difícil para quem tem coração"

Grêmio Recreativo Escola de Samba Mocidade Alegre, SP, 2004.

“...O homem com sua ambição trouxe a tecnologia, fez mal uso da razão, de mãos dadas com a ganância, tem tudo o que lhe deu o criador ô ô, de graça, com amor, no seu futuro pode semear a dor"

Grêmio Recreativo Escola de Samba Império Serrano, RJ, 2005. 


\section{Sumário}

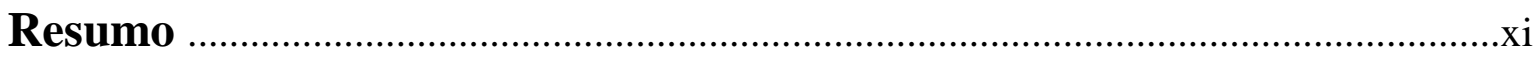

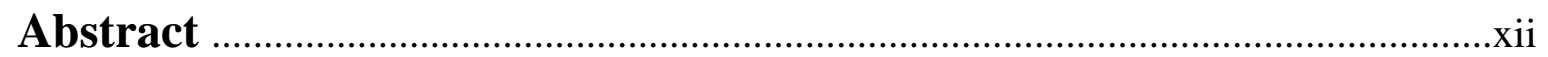

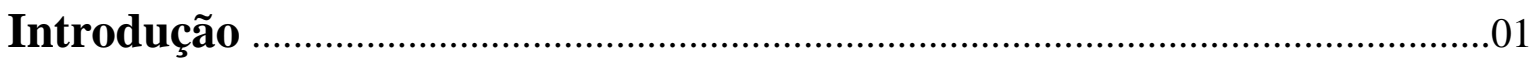

\section{Capítulo 1}

Teoria Crítica da Sociedade e Educação.......................................................................... 10

\section{Capítulo 2}

Alguns dados históricos e conceitos sobre problemas

de aprendizagem e Psicopedagogia

\section{Capítulo 3}

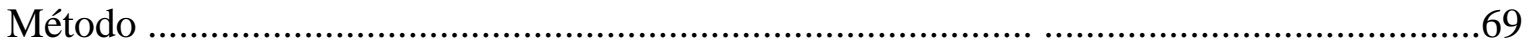

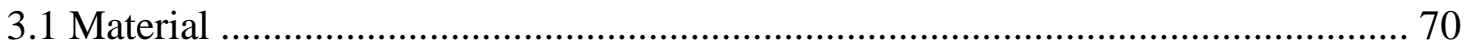

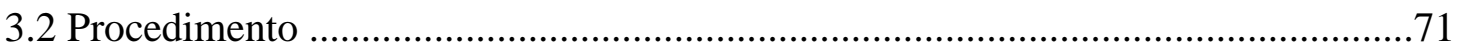

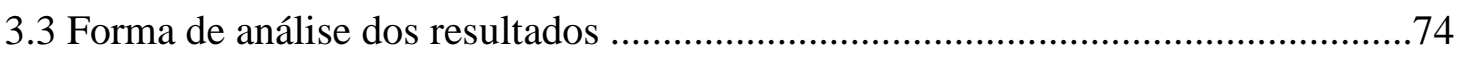

\section{Capítulo 4}

Apresentação dos Resultados 


\section{Capítulo 5}

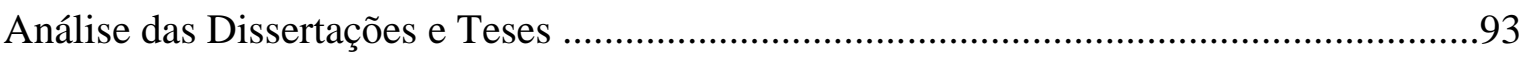

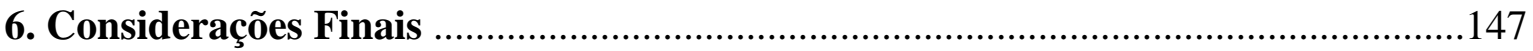

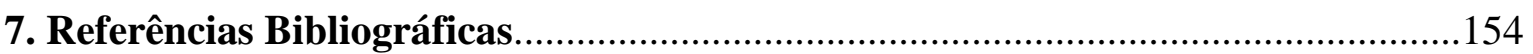

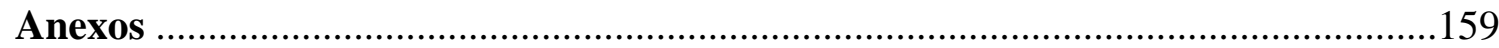

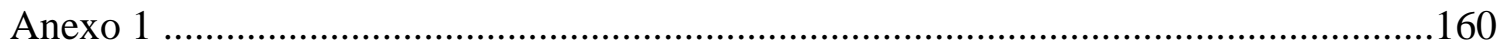

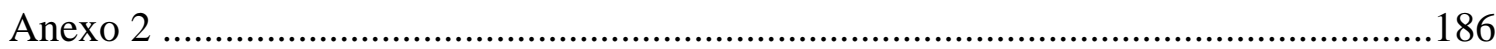




\section{Lista de Tabelas}

Tabela $\mathrm{n}^{\mathrm{o}}$

página

1 Freqüência e porcentagem de dissertações e teses defendidas no período de 1981 a 1998 .78

2 Freqüência e porcentagem de dissertações e teses defendidas no período de 1981 a 1998, contendo o descritor psicopedagogia dividido em períodos de 6 anos

3 Freqüência e porcentagem de dissertações e teses defendidas no período de 1981 a 1998, contendo o descritor psicopedagogia, dividido pelas regiões do Brasil

4 Freqüência e porcentagem de dissertações e teses defendidas no período de 1981 a 1998, contendo o descritor psicopedagogia, dividido por tipo de faculdade

5 Assuntos abordados nas outras dissertações e teses que não foram selecionadas para o presente trabalho, defendidas no período de 1981 a 1998 contendo o descritor psicopedagogia .82

6 Freqüência e proporção de dissertações e teses defendidas no período de 1981 a 1998, contendo o descritor psicopedagogia dividido em períodos de 6 anos, selecionadas para esta pesquisa

7 Freqüência e proporção de dissertações e teses defendidas no período de 1981 a 1998, contendo o descritor psicopedagogia dividido pelas regiões do Brasil, selecionadas para esta pesquisa . .85

8 Freqüência e proporção de dissertações e teses defendidas no período de 1981 a 1998, contendo o descritor psicopedagogia dividido por tipo de faculdade, selecionadas para esta pesquisa

9 Freqüência e proporção de dissertações e teses defendidas no período de 1981 a 1998, contendo o descritor psicopedagogia por nome da faculdade, selecionadas para esta pesquisa .86 
10a Freqüência e proporção de dissertações e teses do programa de Pós-graduação da Psicologia PUC-SP e USP-capital, defendidas no período de 1981 a 2001 contendo o descritor psicopedagogia como assunto ou palavra-chave dividido em períodos de 5 anos

10b Freqüência e proporção de dissertações e teses do programa de Pós-graduação da Educação PUC-SP e USP-capital, defendidas no período de 1981 a 2001 contendo o descritor psicopedagogia como assunto ou palavra-chave dividido em períodos de 5 anos 88

11 Assuntos abordados nas outras dissertações e teses que não foram selecionadas para o presente trabalho defendidas no período de 1981 a 2001 contendo o descritor psicopedagogia como palavra-chave ou assunto no programa de pós-graduação da PUC-SP e USP-capital de Educação

12 Assuntos abordados nas outras dissertações e teses que não foram selecionadas para o presente trabalho defendidas no período de 1981 a 2001 contendo o descritor psicopedagogia como palavra-chave ou assunto no programa de pós-graduação da PUC-SP e USP-capital de Psicologia

13a Freqüência e proporção de dissertações e teses do programa de Pós-graduação da Psicologia PUC-SP e USP-capital, defendidas no período de 1981 a 2001, contendo o descritor psicopedagogia como assunto ou palavra-chave dividido em períodos de 5 anos, selecionadas para esta pesquisa .91

13b Freqüência e proporção de dissertações e teses do programa de Pós-graduação da Educação PUC-SP e USP-capital, defendidas no período de 1981 a 2001 contendo o descritor psicopedagogia como assunto ou palavra-chave dividido em períodos de 5 anos, selecionadas para esta pesquisa .92

14a Freqüência e proporção de concepções entendidas para Psicopedagogia nas dissertações e teses da ANPED .96

14b Freqüência e proporção de concepções entendidas para Psicopedagogia nas dissertações e teses dos programas de pós-graduação das faculdades de Psicologia 102 
14c Freqüência e proporção de concepções entendidas para

Psicopedagogia nas dissertações e teses dos programas de pós-graduação das faculdades de Educação

15a Freqüência e proporção de dissertações e teses, segundo

os objetivos traçados nas pesquisas da $A N P E D$

$15 b$ Freqüência e proporção de dissertações e teses segundo

os objetivos traçados nas pesquisas dos programas de

pós-graduação das faculdades de Psicologia

15 c Freqüência e proporção de dissertações e teses segundo

os objetivos traçados nas pesquisas dos programas de

pós-graduação das faculdades de Educação

16a Frequiência e proporção de dissertações e teses da ANPED

segundo o tipo de pesquisa realizada

16b Freqüência e proporção de dissertações e teses dos programas de pós-graduação das faculdades de Psicologia segundo o tipo de pesquisa realizada

16c Freqüência e proporção de dissertações e teses dos programas de pós-graduação das faculdades de Educação segundo o tipo de pesquisa realizada

17a Freqüência e proporção de dissertações e teses da

ANPED segundo o referencial teórico adotado

17b Freqüência e proporção de dissertações e teses dos programas de pós-graduação das faculdades de Psicologia segundo o referencial teórico adotado

17c Freqüência e proporção de dissertações e teses dos programas de pós-graduação das faculdades de Educação segundo o referencial teórico adotado

18a Dissertações e teses da ANPED segundo as conclusões tiradas nas pesquisas em dados brutos e proporção 118

18b Dissertações e teses do programa de pós-graduação das faculdades de Psicologia segundo as conclusões tiradas nas pesquisas em dados brutos e proporção 
18c Dissertações e teses do programa de pós-graduação das

faculdades de Educação segundo as conclusões tiradas nas pesquisas em dados brutos e proporção

19a Freqüência e proporção de dissertações e teses da ANPED que apresentam os termos adaptação e emancipação

19b Freqüência e proporção de dissertações e teses do programa de pós-graduação das faculdades de Psicologia que apresentam os termos adaptação e emancipação

19c Freqüência e proporção de dissertações e teses do programa de pós-graduação das faculdades de Educação que apresentam os termos adaptação e emancipação

20a Freqüência e proporção de dissertações e teses da $A N P E D$ que apresentam a psicopedagogia voltada para uma educação adaptativa ou emancipatória

20b Frequiência e proporção de dissertações e teses do programa de pós-graduação das faculdades de Psicologia que apresentam a psicopedagogia voltada para uma educação adaptativa ou emancipatória

20c Freqüência e proporção de dissertações e teses do programa de pós-graduação das faculdades de Educação que apresentam a psicopedagogia voltada para uma educação adaptativa ou emancipatória 146 


\section{Resumo}

FONTES, M. A. Concepções de Psicopedagogia no Brasil: reflexões a partir da Teoria Crítica da Sociedade. São Paulo, 2005, 225p. Dissertação (Mestrado). Instituto de Psicologia. Universidade de São Paulo.

Este trabalho de pesquisa tem como objetivos verificar uma parcela da produção científica no Brasil em um período de 20 anos (1981 a 2001), sobre o tema Psicopedagogia, incluindo dissertações e teses, caracterizando esta mesma produção segundo seus objetivos, referenciais teóricos, tipos de pesquisa, conclusões e as concepções de Psicopedagogia entendidas nessas obras. Procurou-se também, observar em que medida a Psicopedagogia está contribuindo para uma educação emancipatória. O referencial teórico utilizado é a Teoria Crítica da Sociedade, dando ênfase ao pensamento de Theodor Adorno. A Psicopedagogia é considerada uma estratégia, área ou prática destinada a entender, prevenir e tratar problemas de aprendizagem. Com as modalidades clínica e institucional, repete na maior parte das vezes os erros cometidos pela Psicologia do século passado: naturalização do indivíduo, reafirmação do psicologismo e do "clinicalismo". Assim, ao desconsiderar os fatores objetivos em suas análises, a Psicopedagogia exclui a contradição existente entre indivíduo e sociedade convertendo-se em ideologia, reafirmando uma educação adaptativa. A melhora dessas condições só se dará a partir da auto-reflexão de seu discurso, abrindo portas para aprimorá-lo Concluindo, a Psicopedagogia de uma maneira geral não colabora para uma educação emancipatória. 


\begin{abstract}
FONTES, M. A. Conceptions of psychopedagogy in Brazil: reflections based upon the critical theory of society. São Paulo, 2005, 225p.Dissertation for Master's Degree in Psychology. University of São Paulo.
\end{abstract}

This paper's objective is to verify the scientifical development of psychopedagogy within a period of 20 years (from 1981 to 2001). The discussion involves theses and research papers including references, types of researches, conclusions e definitions attributed to the concept "psychopedagogy". Special attention was given to measure how much the psychopedagogy contributes towards an emancipated education. The theoretical framework used was based on the "Critical Theory of Society", emphasizing Theodor Adorno's trend of thought. The psychopedagogy is considered either an strategy, an area or a practice that has the purpose of understanding, preventing, and treating problems related to learning. With the clinical and institutional models, the psychopedagogy keeps repeating the same mistakes made by the psychology in the past century: the naturalization of the individual and the use of "psicologismo" and "clinicalismo". Therefore when not considering the objective factors in its analysis, the psychopedagogy excludes the contradiction between the individual and the society and converts in ideology, thus reassuring and adaptive education. The enhancement of these conditions will occur only if there will be a reflexion of its fundamentals therefore facilitating its improvement. Concluding, the psychopedagogy overall does not collaborate for an emancipating education. 


\section{Introdução}




\section{Introdução}

Este trabalho de pesquisa tem como objetivos analisar uma parcela da produção científica no Brasil em um período de 20 anos, entre os anos de 1981 e 2001, sobre o tema Psicopedagogia incluindo dissertações e teses. Pretende-se, sobretudo realizar uma reflexão teórica relacionando alguns fundamentos da Psicopedagogia com os termos "adaptação" e "emancipação" de maneira a observar em que medida a Psicopedagogia está contribuindo para uma "sociedade autônoma" e/ou para uma "sociedade heteronômica" "

A Psicopedagogia tem por definição, segundo o seu código de ética (1996), um campo de atuação interdisciplinar com procedimentos próprios, que trabalha com os processos de aprendizagem levando em consideração as influências da família, da escola e da sociedade.

O termo Psicopedagogia é definido de variadas maneiras por diferentes autores, ocasionando, portanto, uma dificuldade em encontrar uma definição única para o termo. "Quanto mais tentamos elucidá-lo, menos claro ele nos parece" (BOSSA, 2000:17). “A Psicopedagogia ainda busca com clareza a compreensão de si mesma como campo de conhecimento" (MALANGA, 2002: 71).

- Os termos adaptação, emancipação, sociedade heteronômica e sociedade autônoma foram definidos por Adorno e serão apresentados e discutidos no capítulo I. 
Embora não haja ainda uma definição, podemos observar o que é resultado das definições apresentadas por alguns autores até o momento. Dentre elas, observamos que a Psicopedagogia aparece como uma área de conhecimento nova (cf. Macedo, 1991; Andrade, 2002; Souza, 2002), independente (Fasce, 1987), possuindo caráter interdisciplinar (cf. Macedo, 1991; Scoz, 1991; Coll, 1991; Andrade, 2002), abrangendo a Psicologia, Psicanálise, Linguística, Fonoaudiologia, Medicina, Pedagogia entre outras, e estuda questões ligadas à aprendizagem como seus processos e dificuldades envolvidas (cf. Fasce, 1987; Visca, 1991; Scoz, 1991; Souza, 2002; Macedo, 1991). Alguns autores (Fasce, 1987; Souza, 2002; Visca, 1991) comentam sobre os recursos diagnósticos próprios da Psicopedagogia e seu caráter empírico.

Embora ainda não muito bem definida em todos os seus propósitos, a Psicopedagogia tem um de seus objetivos bem claros: se preocupar com os problemas de aprendizagem de forma a contribuir com a diminuição do fracasso escolar (BOSSA, 2000).

A Psicopedagogia tem sua origem na França e se expandiu para outros países incluindo os da América Latina. Na Argentina, país que influenciou essa área no Brasil, a Psicopedagogia passou por três momentos diferentes em relação ao enfoque dado ao estudo, atendendo a demandas histórico-sociais. O terceiro momento da Psicopedagogia na Argentina corresponde ao momento em que no Brasil surgem os primeiros cursos de especialização em Psicopedagogia. Nesses cursos, começaram a ser formados os especialistas em Psicopedagogia. Ou seja, foi a partir desses cursos que a Psicopedagogia passou a se tornar uma área de conhecimento específica, sendo vista como independente da Psicologia e da Pedagogia aqui no Brasil. Será estudado nesse trabalho de pesquisa o 
momento referente ao terceiro período da Psicopedagogia na Argentina, de 1981 ao final do século $\mathrm{XX}^{1}$.

As dissertações e teses analisadas no período entre 1981 e 1998 nesse trabalho foram buscadas na Associação Nacional de Pós-graduação e Pesquisa em Educação $(A N P E D)$. Essa associação busca o desenvolvimento e a consolidação do ensino de pósgraduação e da pesquisa na área da Educação no Brasil. A ANPED possui um acervo dos resumos de dissertações e teses brasileiras publicadas ao longo de anos. Embora não contemple totalmente o período estipulado para este estudo, ela possui um $C D$ ROM contendo as dissertações e teses referentes ao período de 1981 a 1998.

Para poder dar continuidade a nossa pesquisa e contemplar os anos de 1999, 2000 e 2001, recorremos aos materiais (dissertações e teses) publicados em algumas universidades específicas do município de São Paulo, ou seja, primeiro local onde a Psicopedagogia apresentou uma expansão e onde foi criada a Associação Brasileira de Psicopedagogia. A princípio, procurou-se eleger uma universidade pública, uma particular e uma confessional da cidade de São Paulo, de forma a contemplar todos os tipos de universidades. No entanto, não foi encontrada uma universidade ou faculdade particular que possuísse simultaneamente programa de pós-graduação em Educação e Psicologia. Foram pesquisadas as seguintes universidades e faculdades particulares: FMU, UNIP, FAAP, UNISA, UNINOVE, UNIBAN, UNICID. Apenas a UNICID, UNIBAN e UNINOVE possuem mestrado somente na área de Educação, não possuindo doutorado e nem pós-graduação na área de Psicologia. Portanto, optamos em escolher apenas uma

\footnotetext{
${ }^{1}$ Embora o ano de 2001 não faça parte do século XX, ele foi incluído nesse estudo, pois o ano da publicação de uma dissertação ou tese corresponde ao ano de sua conclusão; mas sabemos que o período de duração desse tipo de trabalho corresponde no mínimo dois anos. Portanto, essas teses e dissertações publicadas em 2001 tiveram seu início ainda no século XX.
} 
universidade pública e uma confessional: Universidade de São Paulo (programas de pósgraduação em Psicologia e Educação) e Pontifícia Universidade Católica (programas de pós-graduação Psicologia e Educação).

O referencial teórico utilizado nesta pesquisa será a Teoria Crítica da Sociedade, enfatizando o pensamento do sociólogo, filósofo e músico Theodor W. Adorno que, embora não tenha escrito diretamente sobre o tema Psicopedagogia, também teve uma preocupação em refletir e escrever sobre a Educação.

Adorno apresenta uma visão crítica da Educação. Para ele a Educação deve ter como objetivo a desbarbarização e a não repetição de Auschwitz, obtida por meio da emancipação do homem (ADORNO, 2000).

Ele é um autor que apresenta uma concepção de Educação que se opõe à reprodução do que se encontra instalado na prática. Esta visão de Educação vai contra aquelas concepções que enxergam a Educação como uma área do conhecimento que não questiona os motivos e intenções de tal reprodução.

Tal teoria é relevante para este trabalho, pois faz uma análise da Educação de maneira crítica, ou seja, procura não reproduzir o que já está instalado como o que acontece quando utilizamos teorias acríticas, mas resistir e apontar para uma possível transformação. Segundo Sass (2000), ao discorrer sobre a questão teórica da Psicologia aplicada à Educação, diz que "a crítica deve ser voltada para a sociedade, caso contrário serve apenas à reprodução" (SASS, 2000:60). 
A Psicopedagogia percorreu um caminho enquanto área de conhecimento e de atuação prática tendo deixado para trás algumas explicações e envolvido outras no decorrer de sua história. Inicialmente, a Psicopedagogia era principalmente preventiva e reeducativa o que teve sua dose de importância, pois procurava corrigir os "erros" relacionados à aprendizagem. É de extrema importância que um aluno seja corrigido quando está aprendendo a ler e escrever, por exemplo; afinal, a língua escrita possui regras e convenções que precisam ser respeitadas para que o idioma torne-se universal e seja possível ser compreendido por todos. Portanto, as regras da língua escrita servem como um modelo que precisa ser seguido. No entanto, a Psicopedagogia, enfatizando apenas essa etapa da educação ou considerando um problema de aprendizagem o indivíduo que quer tentar suplantar essa etapa, precisando de se submeter a tratamentos reeducativos, estava servindo basicamente à adaptação dos indivíduos, sobrando pouco ou nenhum espaço para a emancipação dos mesmos.

Mas, atualmente, a Psicopedagogia apresenta uma proposta de olhar o aluno de maneira mais individualizada procurando dar atenção à sua maneira individual e particular de aprender e de lidar com o conhecimento. Como fica a questão acima enunciada? Olhar o aluno apenas de maneira mais individualizada garante a emancipação do mesmo, isto é suficiente ou é condição para a mesma? De fato a Psicopedagogia atual está privilegiando a autonomia e emancipação dos indivíduos, ou apenas está aparecendo com uma roupagem nova, mas apresentando um aspecto mais sutil de uma proposta de Educação apenas para a adaptação, servindo fins regressivos? 
Afinal, a preocupação primordial e atual da Psicopedagogia é apenas adaptar os alunos ao ambiente escolar pelo fato deles não "aprenderem" os conteúdos ou normas exigidos pelo contexto escolar ou dar condições para uma possível emancipação por parte desses alunos? Qual seria seu objetivo: direcionar a educação apenas a uma uniformização sem reflexão ou para a autonomia dos indivíduos? Quando o aluno não se enquadra nesse padrão escolar, como a Psicopedagogia lida com isso? Esse aluno precisa de um tratamento para se ajustar ao padrão social exigido? No que a Psicopedagogia colabora para uma educação emancipatória, para uma educação contra a barbárie? Existe esta preocupação por parte dessa área de conhecimento?

Não se sabe se a Psicopedagogia tem uma intenção de levar alunos a aprender os mesmo conteúdos e atitudes, mesmo que por meio de processos individuais diferentes, mas com fins adaptativos ou de maneira a proporcionar e ter como objetivo final a autonomia dos sujeitos. Uma hipótese é a de que quando algum aluno se desvia do padrão escolar estabelecido, só pelo fato da Psicopedagogia considerar tal acontecimento como problema de aprendizagem em suas várias nuances, haveria uma tentativa de reafirmar uma educação adaptativa, da mesma maneira que a sociedade atual, onde os mais aptos sobrevivem e os diferentes tendem à exclusão. Ou seja, desta maneira a Psicopedagogia viria para reafirmar a sociedade que não contribui para a realização dos indivíduos.

Enfim, para responder a tais indagações e confirmar ou não a hipótese referentes ao tema Psicopedagogia, acredito ser de extrema importância fazer um estudo mais aprofundado sobre este assunto, fazendo uma análise de alguns aspectos 
relacionados a este tema, desde as suas concepções ao longo dos anos, como seus objetivos, referenciais teóricos adotados, tipo preferencial de pesquisa realizada em relação ao tema, locais de publicação desses trabalhos para só depois de tal investigação ser possível tentar discutir ou responder essas perguntas.

A dissertação constará desta Introdução, quatro capítulos e Considerações Finais.

No capítulo 1, serão abordados aspectos da Teoria Crítica da Sociedade, dando uma maior ênfase ao tema Educação.

No capítulo 2, será apresentado um histórico da Psicopedagogia no Brasil e em seus países de origem de maneira a contextualizar esta área do conhecimento.

No capítulo 3, será apresentado o método, incluindo material, procedimento e forma de análise dos resultados a serem realizados na elaboração da pesquisa.

No capítulo 4 serão apresentados os resultados colhidos na pesquisa bibliográfica realizada com o $C D R O M$ da $A N P E D$ e com as dissertações e teses dos programas de PósGraduação em Psicologia e Educação da PUC e USP.

No capítulo 5, serão expostos os registros colhidos nas dissertações e teses pesquisadas, analisando-as a partir de suas concepções e dos termos adaptação e emancipação definidos pela Teoria Crítica da Sociedade. 
Nas Considerações Finais, serão apresentadas as conclusões que foram tiradas diante dos dados colhidos e referencial teórico utilizados na dissertação. 


$$
\text { - Capítulo } 1 \text { - }
$$

\section{Teoria Crítica da Sociedade e Educação}




\section{Teoria Crítica da Sociedade e Educação}

Adorno não escreveu textos ou livros enfocando a Psicopedagogia. Mas desenvolveu reflexões sobre a Educação, que é a principal área de interesse da Psicopedagogia.

Tanto a Psicopedagogia como a Educação participaram do cenário de acontecimentos ocorridos durante o século XX tais como: duas Grandes Guerras Mundiais; disparidades sociais econômicas; ideologias de extrema direita e esquerda; inovações na Ciência e tecnologia etc (HOBSBAWM, 1995).

A Educação especificamente (CAMBI,1999), também procurou acompanhar essas inovações sociais. Há uma abertura das escolas para a massa. Na verdade isso já havia ocorrido no século XIX, mas se intensifica no século XX com o aumento da industrialização. Há inovações tanto em experimentações voltadas para o campo do "fazer" como para teorizações de cunho filosófico, embora a ênfase tenha sido na educação prática. $\mathrm{O}$ ativismo ou Escola Nova marca também os cinqüenta primeiros anos do século, principalmente na Europa Ocidental e EUA. Ela surge na Inglaterra em 1889. O aluno é colocado como centro levando em consideração suas necessidades, seguida de uma preocupação com o ambiente no qual a criança está aprendendo. Enfim, a Escola Nova aparece como protesto à Escola Tradicional. Há um desejo de rompimento com o formalismo, com a disciplina e com a rigidez das instituições escolares de até então. Há um aumento significativo das possibilidades de estudo com a promessa de maiores oportunidades de emprego e conseqüente ascensão social. No 
entanto, com o passar do tempo, os empregos oferecidos passam a ser menores do que o número de pessoas diplomadas ocasionando uma diminuição nos salários oferecidos. No entanto, continua a ilusão de que a educação seja garantia de mobilidade social e sucesso (ARANHA, 1989).

Ao analisar a Educação, Adorno seguiu o mesmo padrão de raciocínio que entende ser necessário na análise de qualquer objeto, ou seja, não se contentar com a superficialidade do dado imediato, mas procurar ir além: o dado particular contém as relações sociais, materiais e históricas que determinam sua essência e sua aparência e fazer uma análise dessas relações é fundamental, caso contrário, a análise torna-se parcial. Ele nega o dado imediato inicialmente, para depois poder compreendê-lo como parte de um processo social. Enfim, em suas análises, incluindo aí a Educação, ele segue de uma certa forma, uma direção contrária ao Positivismo ${ }^{2}$ filosofia marcante do século XX. Digo “de uma certa forma” pois Adorno se contrapõe apenas àquilo que ele reconhece como a parte regressiva do Positivismo; o rigor da dedução e a necessidade da análise dos dados empíricos defendidos pelo Positivismo são entendidos como importantes em uma pesquisa.

Dessa forma, para compreender como Adorno analisa a Educação é necessário entender antes como ele analisa a sociedade, já que a primeira depende da segunda.

\footnotetext{
${ }^{2}$ No Positivismo, o pesquisador afasta o objeto estudado do mundo que o rodeia, isolando-o e controlando variáveis, de maneira a ter um controle total de seus resultados. A idéia envolvida no Positivismo é que os acontecimentos sociais ocorrem numa direção linear ao invés de interdeterminada. Adorno acrescenta uma crítica ao Positivismo que, ao tentar se opor ao determinismo existente nas explicações dos mitos acaba por fazer aquilo que critica, quando já conhece todos os resultados de antemão pelo controle das variáveis. E conclui que o Positivismo se pretende tão auto-suficiente e independente como o indivíduo burguês, que desconsideram a sociedade e suas influências sobre ambos (HORKHEIMER\&ADORNO, 1985).
} 
A sociedade já teria condições objetivas, o conhecimento técnico e científico, de tornar viável uma vida digna para a população, mas, no entanto, o que se pode observar é o predomínio da miséria e da barbárie ${ }^{3}$ (HORKHEIMER\&ADORNO, 1985). O que sempre impulsionou essa busca de conhecimento foi o sentimento de medo diante do desconhecido e o desejo de poder sobre a natureza. O Esclarecimento (Iluminismo) busca o saber racional diante de todos os acontecimentos para livrar os homens do medo da natureza e dotá-los de poder sobre a mesma. Desejavam excluir as explicações irracionais dadas pelos mitos, substituindo-as pelo cálculo preciso, eficiente, prático e útil. Dessa forma, haveria um sistema dedutivo único e a técnica seria a essência deste saber, visando especificamente o método (HORKHEIMER\&ADORNO,1985).

Assim, o Esclarecimento procurou fugir da irracionalidade mítica, mas o que esses autores observaram é que o Esclarecimento acabou reproduzindo a mentalidade mítica, já que o conhecimento prévio dos resultados aparece com o status de espírito absoluto. Existe apenas uma verdade para os fatos e ela é conhecida previamente.

Esses autores mostram que os impulsos humanos não conseguem ser satisfeitos, pois encontram-se subordinados aos desejos de um consumo desenfreado. No capitalismo, as pessoas são consideradas iguais nas relações de mercado não interessando qual é a origem social que provém, mas esta vantagem "é paga por elas próprias ao deixarem que suas possibilidades inatas sejam modeladas pela produção de

\footnotetext{
${ }^{3} \mathrm{O}$ termo barbárie será mais bem discutido durante esse capítulo, mas pode ser entendido a princípio, segundo Adorno (2000:117) como "extremismo, preconceito delirante, opressão, genocídio e toda forma de tortura".
} 
mercadorias que elas podem comprar no mercado (HORKHEIMER \& ADORNO, 1985:27)”.

Como nunca foi possível a individualidade que tornaria os homens iguais em direito de fato, o Esclarecimento acaba usando da coerção social para unificar a coletividade negando, portanto, cada indivíduo tornando-os iguais apenas enquanto normatização (HORKHEIMER \& ADORNO,1985).

O problema do Esclarecimento encontra-se não na racionalidade, mas na utilização irracional da racionalidade. Adorno apresenta perspectivas para libertar-se desse sistema irracional da racionalidade, da barbárie em suas reflexões sobre a Educação.

Este autor concebe a Educação como um processo que tem como objetivos desbarbarizar a sociedade (objetivo prioritário) e levar os indivíduos a desenvolverem a racionalidade $^{4}$ e uma consciência verdadeira ${ }^{5}$. "A tese que gostaria de discutir é a de

\footnotetext{
${ }^{4}$ Os termos "racional" ou "racionalidade" ou ainda "consciência" na Teoria Crítica são entendidos não apenas como capacidade formal de pensar que Adorno considera uma redução dos limites da consciência, ou se analisados em sua perspectiva regressiva como "mero valor de troca" (ADORNO, 2000:105). Em geral, o conceito de racionalidade ou consciência são apreendidos "de um modo excessivamente estreito, como capacidade formal de pensar. Mas esta constitui uma limitação da inteligência, um caso especial da inteligência, de que certamente há necessidade. (...) Aquilo que caracteriza propriamente a consciência é o pensar em relação à realidade, ao conteúdo - a relação entre as formas e as estruturas de pensamento do sujeito e aquilo que este não é. Este sentido mais profundo de consciência ou faculdade de pensar não é apenas o desenvolvimento lógico formal, mas ele corresponde literalmente à capacidade de fazer experiências".(ADORNO, 2000:151). Por exemplo, alguém que deturpa um fato concreto mas consegue dar uma explicação "racional" para esse fato desconsiderando o social, está utilizando a razão apenas como capacidade formal de pensar, mas não está utilizando a racionalidade ou a consciência da maneira como Adorno entende.
}

5 Adorno utiliza o termo "consciência verdadeira" no mesmo sentido em que foi definido na nota de rodapé $\mathrm{n}^{\mathrm{o}} 3$ os termos "racionalidade" e "consciência", de forma a diferenciar da "consciência coisificada" que será melhor explicada no decorrer deste capítulo. "Consciência verdadeira" portanto, é a capacidade de pensar em relação à realidade, ao conteúdo e às experiências realizadas. "(...)Gostaria de apresentar a minha 
que desbarbarizar tornou-se a questão mais urgente da educação hoje em dia" (ADORNO, 2000:155). Para ele, Auschwitz foi o maior exemplo de barbárie do século XX.

Barbárie é definida pelo autor como:

$$
\text { “(...) estando na civilização do mais alto }
$$
desenvolvimento tecnológico, as pessoas se encontram atrasadas de um modo peculiarmente disforme em relação à sua própria civilização - e não apenas por não terem em sua arrasadora maioria experimentado a formação nos termos correspondentes ao conceito de civilização, mas também por se encontrarem tomadas por uma agressividade primitiva, um ódio primitivo ou, na terminologia culta, um impulso de destruição que contribui para aumentar ainda mais o perigo de que toda esta civilização venha a explodir, aliás uma tendência imanente que a caracteriza. (ADORNO, 2000:155)".

É importante esclarecer que desbarbarizar não significa eliminação da agressividade, mas sim, sublimar os instintos agressivos de maneira que sejam conduzidos

concepção inicial de educação. Evidentemente não a assim chamada de modelagem de pessoas, porque não temos o direito de modelar pessoas a partir de seu exterior; mas também não a mera transmissão de conhecimentos, cuja característica de coisa morta já foi mais do que destacada, mas a produção de uma consciência verdadeira." (ADORNO, 2000:141) 
em prol da vida. "A desbarbarização não se encontra no plano de um elogio à moderação, uma restrição das afeições fortes, e nem mesmo nos termos da eliminação da agressividade" (ADORNO, 2000:158). Nem deve ser entendida também como tornar os indivíduos inofensivos ou passivos. "Esta passividade inofensiva constitui ela própria, provavelmente, apenas uma forma de barbárie, na medida em que está pronta para contemplar o horror e se omitir no momento decisivo" (ADORNO, 2000:164). Existem casos em que a agressividade é apresentada como uma energia voltada para a busca de objetivos racionais de maneira a obter condições humanas mais dignas, e isto não deve ser considerado barbárie. Por exemplo, no caso das cirurgias. A barbárie estará presente toda vez que houver uma "regressão à violência física primitiva". Assim como o pensamento, a agressividade pode servir tanto a dominação cega como a seu oposto sendo ambas geradoras da barbárie. Ele acredita ser de extrema importância criar um sentimento de vergonha em relação à barbárie, como forma de combatê-la.

O autor lembra que a barbárie está tão difundida na maneira em que a sociedade encontra-se atualmente, que muitas vezes acabamos sendo coniventes com ela sem perceber, pelo fato de já estarmos identificadas com a mesma, pelo mecanismo que Freud denomina "identificação com o agressor",", camuflando-a e chamando-a por outros nomes, como por exemplo, "realidade". Adorno defende a idéia de que nós atualmente temos um realismo muito valorizado. E que faz parte da educação neste momento, criticar esta supervalorização:

\footnotetext{
${ }^{6}$ Identificação com o agressor é um termo da psicanálise definido por Freud como um mecanismo de defesa utilizado pelo inconsciente (psicanálise). Nesse mecanismo, o indivíduo se sente identificado com o objeto agressor de maneira a se proteger de possíveis ataques por parte desse objeto. Considero como uma forma de se camuflar diante do agressor tornando igual a ele mesmo e, portanto, se protegendo.
} 
"A educação por meio da família, na medida em que é consciente, por meio da escola, da universidade, teria neste momento de conformismo onipresente muito mais a tarefa de fortalecer a resistência do que de fortalecer a adaptação. Se posso crer em minhas observações, suporia mesmo que entre os jovens e, sobretudo, entre as crianças encontra-se algo como um realismo supervalorizado - talvez o correto fosse: pseudorealismo - que remete a uma cicatriz. Pelo fato de o processo de adaptação ser tão desmesuradamente forçado por todo o contexto em que os homens vivem eles precisam impor a adaptação a si mesmos, e, nos termos de Freud, identificando-se ao agressor. A crítica deste realismo supervalorizado parece-me ser uma das tarefas educacionais mais decisivas, a ser implementada, entretanto, já na primeira infância.” (ADORNO, 2000:145)

Atribui como causas da existência da barbárie os fatores subjetivos (psicológicos) e os objetivos, principalmente os que existem independentemente da "alma individual dos homens singulares" e que são encontrados nos sistemas sociais. 
Os fatores psicológicos podem ser explicados por Freud que mostra que por intermédio da cultura, os diversos fracassos experimentados pelas pessoas levam a um sentimento de culpa que são convertidos em agressividade.

Os fatores objetivos são também representados por aqueles chamados por Adorno de "falência da cultura" (2000:164). A cultura faz promessas que não pode cumprir. Uma delas é a promoção de uma sociedade pacífica e que possibilite uma vida digna conseguida a partir da idéia de que todos são iguais e com as mesmas oportunidades, mas a mesma acaba fazendo uma divisão entre os homens que mostrou que eles não seriam tão iguais assim em condições. Uma dessas divisões foi entre o trabalho intelectual e físico. Dessa forma, os indivíduos perderam a confiança nessa promessa e neles próprios e, como consequiência, deslocaram sua raiva contra essa promessa que não se realizou, ao invés de se revoltarem contra o que impede a sua realização.

A desbarbarização pode ser conseguida pela ação da escola, mas devendo levar em consideração que quem gera a barbárie é a sociedade. Portanto, a escola terá uma força pequena nessa alteração: "a chave da transformação decisiva reside na sociedade e em sua relação com a escola" (ADORNO, 2000:117). Mas essa força da escola, mesmo que pequena é essencial, pois se a barbárie é o oposto da formação cultural, então a partir da formação individual será possível a desbarbarização. Mas segundo este autor, o problema é que a própria escola está inserida nessa sociedade produtora da barbárie. Seria necessário, 
portanto, que a escola realizasse uma auto reflexão, de forma a poder de alguma forma se desvincular desses valores sociais.

Segundo Riesman vivemos em uma sociedade heteronômica, ou seja, uma sociedade que "é dirigida de fora" (RIESMAN In: ADORNO, 2000:178). Neste tipo de sociedade, Kant diria que as regras são impostas por uma parcela dominante em termos de força política e o restante da população as aceita sem um prévio questionamento; apenas as cumpre e não há um questionamento se há a necessidade delas existirem da forma que existem (ADORNO, 2000).

Adorno define heteronomia como:

"um tornar-se dependente de mandamentos, de normas que não são assumidas pela razão própria do indivíduo. O que a psicologia denomina superego, a consciência moral, é substituído no contexto dos compromissos por autoridades exteriores, sem compromisso, intercambiáveis, como foi possível observar com muita nitidez também na Alemanha depois da queda do Terceiro Reich" (ADORNO, 2000:124) 
Em contraposição à heteronomia, o autor define autonomia como a produção de uma consciência verdadeira, que tem importância política, pois é a base da democracia com pessoas emancipadas. "O único poder efetivo contra o princípio de Auschwitz seria autonomia, para usar a expressão kantiana; o poder para a reflexão, a autodeterminação, a não participação. (ADORNO, 2000:125)”. Para Adorno, a nossa sociedade e, conseqüentemente, a nossa educação está em um movimento que predomina a heteronomia, ou seja, caminhando principalmente para uma posição oposta daquilo que ele diz ser o caminho para a não repetição de Auschwitz, para uma educação emancipatória.

Adorno entende a emancipação como racionalidade e conscientização. $\mathrm{O}$ autor considera essencial que seja incluída no pensamento e na prática educacional; é um conceito relacionado à dialética ${ }^{7}$ que ocorre na Educação (ADORNO, 2000). É também um conceito dinâmico, que aparece como consequiência de um processo, de "um vir a ser" (ADORNO, 2000:181). Para ele, em uma democracia, a exigência de emancipação é algo evidente, ou seja, para a existência de uma sociedade democrática, a emancipação é um dos pré-requisitos. E ressalta que se refere à emancipação pela conscientização e transformação das estruturas vigentes na educação atual. Ou ainda, procura deixar claro que não está se referindo à emancipação citada muitas vezes em livros pedagógicos como sinônimo de compromisso, autoridade e outros pressupostos que sem uma "verdadeira" emancipação vão contra a democracia (ADORNO, 2000).

\footnotetext{
${ }^{7}$ A dialética que ocorre na Educação é composta da adaptação (capacidade do indivíduo para se moldar à realidade garantindo sua sobrevivência) e da emancipação (conscientização a partir da reflexão). "Mas $a$ realidade sempre é simultaneamente uma comprovação da realidade, e esta envolve continuamente um movimento de adaptação. (...) A educação seria impotente e ideológica se ignorasse o objetivo de adaptação e não preparasse os homens para se orientarem no mundo. Porém ela seria igualmente questionável se ficasse nisto, produzindo nada além de 'well adjusted people', pessoas bem ajustadas. (ADORNO, 2000:143)"
} 
Ele aponta para a situação paradoxal que a Educação está envolvida: uma Educação que não permite a individuação é opressiva e repressiva. Mas também, não oferecer uma base ou referenciais para as pessoas de maneira a tratá-las como plantas que basta serem regadas para florescerem aparece como ideologia ${ }^{8}$. A Educação tem o dever de formar em uma sociedade que incentiva a "deformação", que privilegia o "saber fazer", o pragmatismo, que possui uma escola que semiforma, que produz a cultura da barbárie. A idéia novamente não é uma "fórmula" para educar, mas sim trazer todas essas questões discutidas pelo autor à consciência.

O pensamento educacional do autor envolve uma reflexão das contradições existentes entre sociedade e indivíduo ${ }^{9}$, com o objetivo de conscientizar as pessoas de que a maneira como a sociedade encontra-se estruturada dificulta a realização de uma educação que não privilegie apenas a adaptação, mas também a emancipação.

Ele apresenta algumas críticas à formação (semiformação) e à Educação atual, à Pedagogia, à escola e ao professor que devem ser trazidas à consciência. A escola é uma esfera de alienação social, constituindo um fim em si mesma e o professor é o agente dessa alienação; por isso Adorno defende uma formação adequada dos professores pautada principalmente na conscientização da Ciência entendida como heteronomia, ou seja, uma

\footnotetext{
${ }^{8}$ Ideologia é definida pelo autor como "tentativa de incutir nas pessoas uma falsa consciência e um ocultamento da realidade, além de, como se costuma dizer tão bem, procurar-se impor ‘as pessoas um conjunto de valores como se fossem dogmaticamente positivos " (ADORNO, 2000:80).

${ }^{9}$ Sob o princípio social da equivalência, os indivíduos tornam-se indiferenciados e ameaçados pela barbárie que acaba por aparecer sob forma de "barbárie civilizada". Ou seja, nesse caso, para a sociedade existir, os indivíduos não podem existir. (ADORNO, 1996).
} 
ciência encarada como ritual dispensando o pensamento e a liberdade e a respeito daquilo que ele denomina tabus a cerca do professor.

Para o autor, a formação cultural é semelhante a uma semiformação socializada, a um espírito alienado durante a "formação". Como estamos em uma sociedade basicamente heteronômica, ao invés da formação temos uma semiformação que não leva a uma autodeterminação dos sujeitos e, sim, a elementos culturais aprovados. Diz-se semiformação pois a formação ocorre de forma incompleta, com ênfase na adaptação, como já dito anteriormente, necessária e pré-requisito para a emancipação. "A semiformação passou a ser a forma dominante da consciência atual" (ADORNO, 1996:389). Da maneira que a sociedade está estruturada, ou seja, de maneira administrada, o particular torna-se abafado. O indivíduo é oprimido perante as forças econômicas e sociais apresentadas como dotadas de racionalidade, mas esvaziadas de sentido e que acabam não fornecendo conteúdos para que possibilite a formação dos indivíduos.

Sublinha que muitas vezes, quando pensamos em "formação", relacionamos logo o termo com instrução escolar. Mas a educação transcende esse momento e esse contexto institucional. A indústria cultural garante uma parcela significativa da "formação", por exemplo. E a estrutura social é a principal responsável pelo caminho a ser seguido na formação dos indivíduos.

Critica também na formação, a constante necessidade de se memorizar conceitos e fórmulas. É importante lembrar mais uma vez, que é importante que os conteúdos culturais sejam transmitidos e nesse caso o uso da memória tem seu papel. O passado não 
pode ser anulado; ele é a base para possíveis evoluções. Mas este passado deve ser absorvido de maneira refletida ao invés de ser apenas mais uma página memorizada imediatamente, sem uma reflexão prévia. Só pelo uso da reflexão será possível ver o que deve ser alterado no passado para o presente e para o futuro. A memorização sem uma prévia reflexão para evitar a "perda de tempo" é tão prejudicial quanto não tomar conhecimento desses conteúdos.

O que Adorno traz de importante e original entre outros elementos é que não apenas as pessoas que não têm acesso à escola e à cultura não estão tendo uma formação adequada, mas também aqueles que seguem as determinações impostas pelo processo escolar possuindo todos os títulos possíveis e sendo respeitadas pela sua "formação cultural”, também podem ser pessoas semiformadas. Aliás, ele se preocupa mais com essas pessoas semiformadas do que as "não formadas" (se é que isto é possível). Uma pessoa que se considera não formada ainda carrega consigo um pouco de ingenuidade e ceticismo. Uma pessoa semiformada costuma ser conformada à realidade, muitas vezes justificando-a e considerando-a como algo natural e imutável.

Em relação à Pedagogia, ele lembra que no século passado, essa área do conhecimento procurou dar ênfase à reeducação, impondo dessa forma a adaptação, que só pelo fato de ser uma imposição já caminha no sentido contrário de uma democracia. Ou seja, um dos erros recorrentes da Pedagogia que revela seu lado irracional é a insistência em adotar como diria Adorno (2000), teorias totalmente equivocadas, teorias que não levam em consideração a influência que a sociedade tem sobre a Educação. A maior parte das teorias educacionais utilizadas pela Pedagogia defende a idéia formal de que a Educação deve ser voltada simultaneamente para fins 
individuais e sociais. Mas desconsidera que em termos práticos esse tipo de idéia é inviável considerando os moldes da nossa sociedade atualmente. Não utilizam teorias que façam uma crítica social e que discutam os entraves que a sociedade atual heteronômica ${ }^{10}$ cria para o indivíduo. A crítica à Educação, portanto, é de não haver sentido enquanto pura reprodução social, mas que deve ser dirigida para uma autoreflexão crítica, ou seja, levar os homens à tomada da consciência dos mecanismos que os tornam capazes de atos tão violentos. Mediante essa conscientização poderia ser trilhado um caminho de emancipação. Embora apenas a conscientização não seja suficiente para transformar em termos práticos a barbárie, a educação enquanto esclarecimento pode criar, em um primeiro momento, um espaço para uma posterior tomada de atitude que não dê margem a sucessivas repetições como o que vem ocorrendo até o momento. Explica o fracasso educacional também pelo cultivo da dupla hierarquia ${ }^{11}$ que há na escola (oficial e não-oficial), em especial a segunda delas.

Em termos práticos, Adorno (2000) é contra a educação que valoriza a capacidade de suportar a dor, contra a educação que forma seres com "consciência

\footnotetext{
10 Adorno ilustra quais seriam estes entraves provenientes de uma sociedade heteronômica "O motivo evidentemente é a contradição social; é que a organização social em que vivemos continua sendo heteronômica, isto é, nenhuma pessoa pode existir na sociedade atual realmente conforme suas próprias determinações; enquanto isto ocorre, a sociedade forma as pessoas mediante inúmeros canais e instâncias mediadoras, de um modo tal que tudo absorvem e aceitam nos termos desta configuração heteronômica que se desviou de si mesma em sua consciência." (ADORNO, 2000:181)

${ }^{11}$ Adorno entende as hierarquias dentro da escola da seguinte forma: "a hierarquia oficial, conforme $o$ intelecto, o desempenho, as notas, e a hierarquia não-oficial, em que a força fisicica, o "ser homem" e todo um conjunto de aptidões prático-físicas não honradas pela hierarquia oficial desempenham um papel. $O$ nazismo explorou esta dupla hierarquia inclusive fora da escola, na medida em que incitou a segunda contra a primeira, tal como incitaria o partido contra o Estado na macropolítica. A pesquisa pedagógica deveria dedicar especial atenção à hierarquia latente na escola. As resistências das crianças e dos jovens, igualmente institucionalizadas na segunda hierarquia, foram em parte certamente transmitidas pelos pais. Muitas baseiam-se em estereótipos herdados; muitas, porém, como procurei mostrar, baseiam-se na situação objetiva do professor." (ADORNO, 2000:110-111).
} 
coisificada $^{12 \%,}$, contra a competitividade, a passividade, a uniformização, a mera transmissão de conhecimentos, ou seja, é contra tudo aquilo que enfraqueça o indivíduo.

Ele faz referência ainda à importância da construção de uma verdadeira democracia. Segundo ele, essa só será possível se houver sujeitos emancipados.

Adorno (2000) mostra que a adaptação tem sua importância também, seja social, seja no desenvolvimento do indivíduo para alcançar a autonomia. Inicialmente, ela não deve ser entendida como uma dicotomia em relação à autonomia, mas como um passo, uma etapa para a conquista da autonomia. Assim a adaptação pode ser direcionada para objetivos racionais ou regressivos. Cabe a adaptação favorecer seus objetivos racionais, nesse caso, como objetivo de transmissão de valores racionais da nossa cultura. "O modo pelo qual - falando psicologicamente - nos convertemos em um ser humano autônomo, e portanto, emancipado, não reside simplesmente no protesto contra qualquer tipo de autoridade" (ADORNO, 2000d:176-177). Mas isto não implica em conservar esta etapa sempre e ressaltá-la. "Não tem sentido uma escola sem professores, mas que, por sua vez, o professor precisa ter clareza quanto a que sua tarefa principal consiste em se tornar supérfluo" (BECKER In ADORNO, 2000d:177). Levando em consideração esse aspecto, a educação também teria o papel de adaptar o indivíduo à sociedade, lembrando que a existência de um modelo pré-estabelecido é fundamental para a sobrevivência da humanidade; é a partir desse modelo que a cultura

${ }^{12}$ Consciência coisificada: "Esta é sobretudo uma consciência que se defende em relação a qualquer vir-aser, frente a qualquer apreensão do próprio condicionamento, impondo como sendo absoluto o que existe de um determinado modo". (ADORNO, 2000:132) 
é transmitida de geração a geração. Vale lembrar também que ter um modelo é fundamental para o desenvolvimento de qualquer ser humano, já diria Freud (1921) em seus escritos sobre o desenvolvimento humano, enfatizando a importância da identificação. Portanto, a autoridade é essencial, no entanto, o problema é a falta da autoridade esclarecida ${ }^{13}$. A sociedade tende a premiar e reforçar os indivíduos que apresentam uma atitude adaptativa e o autor não vê problema nesse ato, no entanto, como já dito acima, que seja adaptação naquilo que se refere à incorporação da cultura, de suas regras racionais. Inclusive comenta no texto "Educação e Emancipação" (2000), que pesquisas realizadas nos EUA pela autora Else Frenkel-Brunswik demonstraram que crianças bem comportadas e adaptadas nas escolas tendem no futuro a ser pessoas autônomas antes que crianças refratárias: "As crianças chamadas comportadas tornaram-se pessoas autonômas e com opiniões próprias antes das crianças refratárias, que uma vez adultas, imediatamente se reúnem com seus professores nas mesas dos bares, brandindo os mesmos discursos"(ADORNO, 2000:177). O problema é a escola reforçar apenas essa situação adaptativa e não dar condições ou não permitir que os alunos alcancem a autonomia.

Becker (ADORNO, 2000) lembra que a emancipação é um problema mundial. Comenta que, na Alemanha, a adaptação era o êxito principal da Educação Infantil. Conta que na ex-União Soviética também predominava um estilo autoritário de educar. Adorno (2000) também concorda com Becker dizendo que esse problema

\footnotetext{
${ }^{13}$ Adorno com a citação a seguir exemplifica o que vem a ser uma autoridade esclarecida: "Determinadas manifestações de autoridade, que assumem um outro significado, na medida em que já não são cegas, não se originam do princípio da violência, mas são conscientes, e, sobretudo, que tenham um momento de transparência inclusive para a própria criança; quando os pais "dão uma palmada" na criança porque ela arranca as asas de uma mosca, trata-se de um momento de autoridade que contribui para a desbarbarização"(ADORNO,2000).
} 
ultrapassa em muito os limites dos sistemas políticos, e exemplifica com os EUA que trazem em sua educação traços fortes de individualismo e adaptação.

\begin{abstract}
“Aliás, trata-se de uma contradição que percorre toda a história burguesa. Que ideologias de caracterização tão diferentes como a ideologia vulgar do pragmatismo, na América, e a filosofia de Heidegger, na Alemanha, terminem por coincidir justamente no mesmo, isto é, na glorificação da heteronomia... (ADORNO, 2000d:175176)"
\end{abstract}

Adorno aponta dois caminhos para a melhoria da Educação. Um deles é uma maior ênfase na Educação Infantil, pois é na primeira infância que a identidade é formada, e o modelo de autoridade nessa época é fundamental para auxiliar a criança na maneira de elaborar sua agressividade e obter autonomia. Becker (2000) também comenta sobre a Educação Infantil dizendo: “a criança não pode ser nem submetida autoritariamente à violência, nem submetida à insegurança total pelo fato de não se oferecer a ela nenhuma orientação. (Becker In:ADORNO,2000:167)”. O outro caminho é o que denomina "esclarecimento geral" das pessoas utilizando a crítica social, ou seja, uma conscientização quanto às constantes "enganações" que os homens estão expostos permanentemente na nossa sociedade, apontando para a contradição social 
existente e para a identificação cega com o coletivo. "A consciência de todos em relação a essas questões poderia resultar dos termos de uma crítica imanente, já que nenhuma democracia normal poderia se dar ao luxo de se opor de maneira explícita a um tal esclarecimento" (ADORNO, 2000:183).

Finalmente aponta para o paradoxo da Educação: com objetivos de adaptação e emancipação, e diz que da maneira que a sociedade está estruturada fica praticamente impossível uma harmonia com o projeto de emancipação que a Educação deveria priorizar também. E é por isso, por apenas o lado da adaptação estar sendo priorizado, que a Educação deveria ser direcionada para a contradição e resistência. " ... a única concretização efetiva da emancipação consiste em que aquelas poucas pessoas interessadas nesta direção orientem toda a sua energia para que a educação seja uma educação para a contradição e para a resistência (ADORNO, 2000:183)".

Adorno, portanto, prefere falar muitas vezes em emancipação ao invés de educação. “(...) Evito de propósito a palavra “educar”... (ADORNO, 2000:185).

O autor (2000), como já dito anteriormente procura direcionar suas reflexões sobre educação em um sentido que seja contra qualquer mecanismo que enfraqueça ou prejudique o indivíduo. Sendo assim, não aprova modelos ou projetos educacionais que valorizem a competitividade, a capacidade de suportar a dor, a passividade, uniformização, apenas transmissão de conteúdos e outras propostas que seguem esse mesmo estilo de visão de educação, que já foram apresentadas por outros teóricos e que ainda hoje são utilizadas e valorizadas. 
Becker (In ADORNO, 2000) sugere como exercício da autonomia que o próprio aluno participe individualmente ou em grupos da definição de seu programa de estudos e da seleção de sua programação de disciplinas, podendo ver o resultado de cada decisão tomada ao invés de "receber" apenas decisões tomadas por outros, obviamente levando em consideração que esse aluno tenha uma base que lhe possibilite realizar escolhas. Adorno (2000) sugere que, nas escolas em geral, os alunos fossem assistir filmes comerciais, sendo apontado em cada um deles o conteúdo de falsidade presente neles, e que fossem instruídos e conscientizados sobre os demais programas da televisão, por exemplo, principalmente aqueles que querem vender uma imagem de que o mundo vive em felicidade e em harmonia, escondendo toda a barbárie existente. Sugere o mesmo para as músicas e programas de rádio. "Assim tenta-se simplesmente começar despertando a consciência quanto a que os homens são enganados de modo permanente... de que o mundo quer ser enganado" (ADORNO, 2000:183). Acredita que desta maneira essa crítica seria uma forma de se despertar a consciência das pessoas e, assim, começar a desenvolver uma verdadeira democracia que só é possível com sujeitos emancipados.

Adorno diz que a dificuldade para se alcançar a emancipação é dentre outras, a insegurança em relação a nossa capacidade de enfrentar os problemas relacionados à educação, levando em consideração sua amplitude e dificuldades intrínsecas e extrínsecas (contradição social). A outra dificuldade que enfrentamos em relação aos problemas educacionais é a maneira de se fazer uma intervenção que converta em resultados efetivos. 
E complementa apontando para a dificuldade e a resistência em relação a algo que temos a ânsia de transformar. 


\section{- Capítulo 2 -}

\section{Alguns dados históricos e conceitos sobre problemas de aprendizagem $e$ Psicopedagogia}




\section{Alguns dados históricos e conceitos sobre problemas de}

\section{aprendizagem e Psicopedagogia}

A Psicopedagogia segundo o Novo Dicionário Aurélio é definida como uma “aplicação da psicologia experimental à pedagogia” (1995). Surge principalmente em função dos problemas de aprendizagem e do fracasso educacional (SAMPAIO, 2003). A preocupação com a aprendizagem e seus problemas teve origem no século XIX na Europa por parte de profissionais da Educação, Filosofia e Medicina (BOSSA, 2000). Esse interesse em compreender e solucionar os problemas de aprendizagem revelou-se para Merry (1985), paralelamente com a busca de compreender outras questões como as deficiências sensoriais, debilidade mental e outros problemas que poderiam comprometer a aprendizagem. Historicamente como na sua origem, a Psicopedagogia procurou de uma maneira geral, buscar meios e técnicas consideradas científicas para ajudar o educando na resolução de seus problemas de aprendizagem sem um prévio questionamento das mesmas.

O problema ou dificuldade de aprendizagem, chamado também de distúrbio de aprendizagem, possui uma conotação médica negativa e localizada no indivíduo segundo Moysés e Collares (1992): “anormalidade patológica por alteração violenta na ordem natural da aprendizagem” (MOYSES e COLLARES, 1992:31). Ainda atualmente é muito utilizada por professores, psicólogos, pedagogos e psicopedagogos. 
Aliás os distúrbios/problemas/dificuldades ${ }^{\mathbf{1 4}}$ de aprendizagem são objeto de estudo da Psicopedagogia.

Como já comentado no parágrafo anterior o distúrbio de aprendizagem tem explicações baseadas em aspectos orgânicos. Moysés e Collares (1992) citam a definição para o termo apresentada pelo National Joint Comittee for Learning Disabilities, nos EUA, em 1981:

"Distúrbios de aprendizagem é um termo genérico que se refere a um grupo heterogêneo de alterações manifestas por dificuldades significativas na aquisição e uso da audição, fala, leitura, escrita, raciocínio ou habilidades matemáticas. Estas alterações são intrínsecas ao indivíduo e presumivelmente devidas à disfunção do sistema nervoso central. Apesar de um distúrbio de aprendizagem poder ocorrer concomitantemente com outras condições desfavoráveis (por exemplo, alteração sensorial, retardo mental, distúrbio social e emocional) ou influências ambientais (por exemplo, diferenças culturais, instrução insuficiente/inadequada, fatores psicogênicos), não é resultado direto destas condições ou influências" (MOYSES e COLLARES, 1992:32).

A "biologização" do problema de aprendizagem faz com que a busca dele ocorra no próprio indivíduo portador do problema. Dessa forma, não se analisa os determinantes sociais que produzem os indivíduos que não conseguem aprender. Não

\footnotetext{
${ }^{14}$ Segundo Moyses e Collares (1992) a expressão "dificuldades de aprendizagem” é utilizada atualmente com a intenção de procurar reduzir a crítica feita em relação à posição de que o problema de aprendizagem teria origem orgânica, causada por alguma disfunção do sistema nervoso central.
} 
queremos dizer com isso que não exista a possibilidade de problemas originados por fatores neurológicos como, por exemplo, a dislexia, em que é possível se constatar uma diferença anatômica originada por seqüela de uma patologia do sistema nervoso central. O erro está em colocar a origem de qualquer problema de aprendizagem como originado por causas orgânicas sem essa causa ser diagnosticada de fato.

Hinshelwood, em 1895, oftalmologista, publicou artigos que confirmam a teoria acima a partir de casos de cegueira verbal que, segundo ele, estariam relacionados a problemas genéticos que levariam a não aprendizagem (MOYSES e COLLARES, 1992). No entanto, ele fez essas afirmações sem que sua teoria tivesse qualquer tipo de comprovação.

Já em 1918 temos Strauss, neurologista americano, que conclui que os distúrbios de comportamento e, conseqüentemente, os de aprendizagem teriam sua origem em uma lesão cerebral mínima (MOYSES e COLLARES, 1992).

Para Hinshelwood e para Strauss, o raciocínio utilizado para explicar o aparecimento dos problemas de aprendizagem eram os mesmos; algumas pessoas com doenças neurológicas apresentavam alterações em seus comportamentos incluindo os de aprendizagem, logo, o raciocínio inverso era utilizado: quando alguém apresentava problema de aprendizagem era porque possuía algum problema neurológico, mesmo sem existir comprovações para esse tipo de conclusão. E contornavam qualquer tipo de crítica da seguinte forma: a lesão cerebral mínima reportava a uma lesão suficiente para causar problemas comportamentais, mas por ser mínima não chegava a causar alterações neurológicas visíveis. Como é possível observar em todas essas explicações, 
a medicina dotada de muita força política naquela época, e ainda atualmente, procurava dar explicações ideológicas para os problemas de aprendizagem, não que em alguns casos o problema de aprendizagem não possa ter origem orgânica. O problema é generalizar a causa deste tipo de problema como sendo única, orgânica não dando abertura para outras possibilidades.

Só em 1950 que Vernon, psicólogo inglês, refuta essas teorias. No entanto, em 1957, na medicina os conceitos de lesão cerebral mínima comentados no parágrafo anterior, e hiperatividade passaram a ser tratados através de drogas químicas (MOYSES e COLLARES, 1992).

Em 1962, em um simpósio em Oxford, profissionais reuniram-se para discutir a lesão cerebral mínima chegando a conclusão que não existia evidência de sua real existência. Dessa forma, assumiram que estavam errados, no entanto, continuaram sem questionar a principal falha na pesquisa com problemas de aprendizagem. "Reconheceram não haver lesão e proclamaram a existência de uma disfunção. Surge, assim, a disfunção cerebral mínima (DCM)” (MOYSES e COLLARES, 1992:37). Optaram por chamar de disfunção ${ }^{15}$ já que não conseguiam encontrar a lesão. A DCM tem diversas manifestações clínicas tais como: "hiperatividade, agressividade, distúrbio de aprendizagem, distúrbio de linguagem, incoordenação(sic) motora, déficit de concentração, instabilidade de humor, baixa tolerância a frustrações e outras menos comuns" não existindo um número mínimo de sintomas para diagnosticar sua existência. E mais que isso, não existem critérios e definições para especificar do que se trata cada um desses sintomas, procedimento comum na medicina. Moyses e

15 “Alteração na função sem correspondência anatômica” (MOYSES eCOLLARES, 1992:38). 
Collares (1992) acrescentam que é uma doença que diferentemente de qualquer outra é baseada em critérios de normalidade.

Ainda em 1981 a disfunção cerebral mínima continua sendo aceita pelos estudiosos dos problemas de aprendizagem como critério de causa de problemas de aprendizagem, no entanto considerando como possível a existência de outras causas que pudessem agir concomitantemente com essa. Por exemplo, o problema poderia ter origem na DCM e na escola (MOYSES e COLLARES, 1992).

Toda essa especulação e a descoberta de fatores relacionados com a aprendizagem passam a exigir profissionais para preencher esse novo espaço no mercado de trabalho. O psicopedagogo surge nesse contexto. Apesar disso, a indústria farmacêutica continua a participar dessa "nova epidemia" produzindo remédios para ajudar na cura dos problemas de aprendizagem. Moyses e Collares (1992), ao citar Coles, afirmam que 1 milhão e 800 mil crianças americanas tomaram ritalina no ano de 1977. E existiam estatísticas de que 5\% das crianças em idade escolar deveriam tomar tal medicamento.

Mais uma vez é importante lembrar da falta de critérios para se definir comportamentos, sempre havendo discordância entre opiniões de diferentes pessoas ou profissionais da área para identificar, por exemplo, no caso da hiperatividade, quando uma criança é esperta, ativa, desconcentrada etc. 
Mais atualmente, após os anos 80, foi criada a ADM (Attention Déficit Disorders - Distúrbios por Déficit de Atenção) pela Academia Americana de Psiquiatria devido à falta de precisão na definição de diversos termos como a DCM, hiperatividade, distúrbios de aprendizagem etc. (MOYSES e COLLARES, 1992) A nova explicação para toda essa gama de problemas estaria relacionada com a "atenção" que refletiria no comportamento e na aprendizagem da criança. Os sintomas relacionados com este déficit são: “falha em terminar tarefas, freqüentemente parece não ouvir, freqüentemente age sem pensar, freqüentemente tem dificuldade de atenção, freqüentemente tem distúrbios de aprendizagem" (MOYSES e COLLARES, 1992:45). Acrescentam que esses alunos passam a ter outro sintoma: mais tarde na adolescência, revelam índice de comportamento delinqüente e uso de drogas com porcentagem mais alta do que as crianças que não apresentam o mesmo déficit. Esquecem-se, portanto, que só as drogas que foram consumidas quando crianças para tratar do problema da ADD já revelam uma possível dependência física e psíquica por parte das mesmas, mas que foram geradas pelos próprios profissionais que hoje criticam o comportamento desses adolescentes.

O que é possível observar é que mesmo com a passagem do tempo, ainda assim existe uma tendência a insistir nas causas orgânicas como geradoras dos problemas de aprendizagem, minimizando assim a nossa responsabilidade ao desconsiderar as causas de cunho social como causadoras dos problemas de aprendizagem. Ao colocar o problema na criança, nos ausentamos de responsabilidade por ele. Não considerar a questão social implica em criar explicações para justificar antigas idéias não possibilitando emancipação. 
A Psicopedagogia, área preocupada em entender e sanar tais problemas de aprendizagem passa a existir no final do século XIX na Europa. Na Europa, esse século foi fortemente influenciado pelos ideais iluministas. A Ciência marcada pelo Positivismo. A Pedagogia francesa desse período foi promulgada em 1881 e 1882 tornando-se paradigma para sistemas educacionais de outros países (SAMPAIO, 2003). Defendia a idéia de que todos indivíduos são capazes de aprender. Até então, sempre existiram crianças que apresentavam dificuldades para aprender, mas esse fato não era considerado um problema. Os próprios professores procuravam contornar essa situação no dia a dia escolar (SAMPAIO, 2003).

A área da Psicologia foi marcada nessa época entre outros autores por Francis Galton (1822-1911) (GOULD, 1999), fundador da eugenia ${ }^{\mathbf{1 6}}$ e criador da "psicologia diferencial - psicologia que se quer investigação quantitativa e objetiva das diferenças existentes entre individuos e grupos" (PATTO, 2000:54).

Galton desenvolveu na Psicologia as idéias sobre inteligência herdada a partir de testes mentais que marcaram época na última década do século XIX em diante. Tinha como objetivo medir a capacidade intelectual e comprovar que a mesma possuía uma determinação hereditária. Procurava assim, aproximar a Psicologia das ciências biológicas. Ou seja, a Psicologia diferencial é um reflexo do Esclarecimento funcionando como uma adaptação da Psicologia à ciência da época.

\footnotetext{
${ }^{16}$ Eugenia: "Ciência que visava controlar e dirigir a evolução humana, aperfeiçoando a espécie através do cruzamento de indivíduos escolhidos especialmente para este fim" (PATTO, 2000:56).
} 
Mais tarde, devido a questionamentos vindos de outros teóricos, Galton procurou amenizar seu critério racial, argumentando que a distribuição de dons e talentos acontecia aleatoriamente entre famílias. Vale lembrar "numa ordem social em que o acesso aos bens materiais e culturais não é o mesmo para todos, o "talento" é muito menos uma questão de aptidão natural do que de dinheiro e prestígio... " $\mathrm{O}$ erro está em "acreditar que é natural ${ }^{17}$ o que, na verdade, é socialmente determinado" (PATTO, 2000:57).

Bisseret (1979) chama a atenção para a função que a Psicologia passa a ter: mantenedora da ordem social resolvendo os possíveis conflitos sociais existentes: "esta ciência deveria permitir detectar as "verdadeiras" aptidões escondidas, segundo as quais cada um teria atribuído seu lugar na sociedade" (BISSERET, 1979:46).

Como podemos ver a Psicologia mesmo quando procura colocar-se diante dos problemas de uma forma neutra, dizendo ser natural aquilo que é determinado socialmente, ela acaba ocultando sua própria força política. Ela acaba por justificar a estrutura social sem precisar utilizar a força física, já que o poder ideológico por ele só já contribui para a domesticação dos indivíduos (PATTO, 1995). É importante notar se a Psicopedagogia não está caminhando no mesmo sentido...

Segundo Merry (1985), os primeiros educadores a realizarem trabalhos com crianças portadoras de problemas de aprendizagem foram: Itard, Pestalozzi, Pereire e

\footnotetext{
${ }^{17} \mathrm{O}$ termo aptidão é muito utilizado ainda atualmente principalmente nas instituições escolares, sendo motivo para atribuir fracasso escolar para alunos. Segundo Bisseret (1979), a palavra aptidão é ainda atualmente muito empregada ainda com o sentido "biologizado". "Aptidão, hereditariedade, seleção, fazem pois, parte do mesmo campo semântico, no momento em que crescem as exigências em matéria de ensino" (Bisseret, 1979:47)
} 
Séguin. Esses profissionais, na maioria médicos provenientes de instituições asilares, procuraram trazer uma nova abordagem para os problemas infantis. Sampaio (2003), ao citar Izabel Galvão e Luci Banks-Leite, denomina esses profissionais de médicospedagogos. Segundo a mesma autora, Jean Itard em 1800 apresenta a primeira proposta de tratamento infantil com objetivo de reintegrar um garoto considerado selvagem à sociedade. No decorrer desse tratamento, Itard concluiu que o progresso da cura do problema do menino dependia do desenvolvimento de sua inteligência (SAMPAIO, 2003). Um outro exemplo desses profissionais médicos-pedagogos foi o de Maria Montessori, psiquiatra italiana, que no final do século XIX criou o método denominado sensorial para atender crianças com deficiência mental e que atualmente é utilizado em escolas para alunos em geral.

O século XIX foi muito influenciado pelas idéias da medicina e das ciências biológicas, e a aprendizagem humana como já dito anteriormente, recebeu também a influência dessas vertentes: visão orgânica das aptidões humanas envolvidas por idéias racistas. Portanto, não é à toa que os principais teóricos a desenvolver idéias sobre a aprendizagem fossem médicos ou médicos-pedagogos. No entanto, vale lembrar que, na passagem do século, essas idéias são acrescidas da influência ambiental: " $a$ ambigüidade imposta por esta dupla origem será uma característica do discurso sobre os problemas de aprendizagem escolar e da própria política educacional, nele baseada, nos países capitalistas no decorrer de todo o século XX” (PATTO, 2000:5859).

Segundo SAMPAIO (2003), o aparecimento das classes especiais surge nessa época. Desirée Magloire Bourneville, seguidor das idéias de Itard e que era responsável 
pelas crianças asiladas no hospital de Bicêtre, cria um projeto de asilos-escolas e de reformas para tratar crianças asiladas e que sofriam psíquica e neurologicamente. Acreditava que essas crianças poderiam ser beneficiadas pela escolarização. Seu projeto não foi aceito pela comunidade científica da época. Consequentemente, Bourneville passa a reivindicar a criação de salas especiais para atender as crianças asiladas ao Ministério de Instrução Pública. No aparecimento dessas classes, fica já embutida a idéia de que um sujeito que não atendesse o padrão definido a priori, já teria seu destino traçado; sua relação com o conhecimento, com a escola e com o mundo já ficava a partir daí estabelecida. Ou seja, embora houvesse uma nova modalidade de classe dentro das escolas (classes especiais), a estrutura educacional não se alterou.

Conforme a mesma autora (2003), em 1899, é criada a "Sociedade Livre para o Estudo Psicológico da Criança" com o objetivo de integrar diferentes especialistas da infância. Nessa Sociedade, os profissionais psicólogos procuravam estudar alunos, tornando-os objeto de estudo e os professores procuravam pesquisar maneiras de orientar seus alunos para uma instrução moral adequada.

Binet (1857-1911) pesquisador da Psicologia Experimental que possuía como objeto de estudo a inteligência, foi convidado a participar dessa Sociedade. Decidiu estudar a medição da inteligência por meio da craniometria inicialmente em seus estudos (GOULD, 1999). Depois de experimentar o fracasso do enfoque médico, procurou em 1904, utilizar técnicas psicológicas para o mesmo estudo, criando assim uma escala de inteligência. 


\footnotetext{
"Em sua escala, Binet tentou 'separar inteligência natural e educação': 'é só a inteligência que tratamos de medir, prescindindo o mais possível do grau de educação que a criança possui... Não the pedimos que escreva ou leia nada, e tampouco a submetemos a qualquer teste que pudesse ser resolvido com base numa aprendizagem por memorização.' Uma característica particularmente interessante destes testes é o fato de que, quando é necessário, eles nos permitem liberar dos entraves escolares uma bela inteligência inata” (GOULD, 1999:154)
}

Ele criou a noção de normalidade e de desvios da norma, ou seja, do conceito de anormalidade. Assim, certos comportamentos que anteriormente à criação do conceito de anormalidade não lhes eram atribuído valor e eram resolvidos pelos próprios professores como questões "naturais" do cotidiano escolar passaram então a serem considerados como problemas. Vale lembrar, no entanto, que independentemente da causa do mau desempenho escolar, ele entendia que era obrigação da escola ajudar o aluno melhorar. "Ainda que algumas crianças tivessem uma incapacidade inata para obter resultados normais, todas podiam melhorar se recebessem a assistência adequada" (GOULD, 1999:155).

Binet também postulou quais seriam os principais fatores que causariam tais anormalidades. Ele dividiu tais fatores em extrínsecos e intrínsecos. Os fatores extrínsecos eram: proveniência de família camponesa, origem estrangeira e ingresso 
tardio na escola. Os fatores intrínsecos eram: lentidão de espírito, defeitos de inteligência, caráter bizarro e irritadiço. Para Binet, portanto, alunos anormais já tinham seu "destino" traçado: insucesso escolar. Como podemos observar, nas idéias de Binet havia a polaridade visão orgânica-ambiental, e por trás da objetividade da psicometria, havia um forte preconceito nessa teoria que já foi criticada por diversos autores. A visão de Adorno em relação à Educação, como já vista no capítulo anterior, difere em muito da maneira de compreender os problemas educacionais segundo Binet e seus seguidores. Para estes últimos, aluno com problemas é sinônimo de exclusão de quem não se inclui na uniformidade idealizada por ele. Já na visão de Adorno, a própria uniformidade é que se apresenta como problema. Ele exemplifica com aquelas respostas padrão, sem reflexão, que todos nós já temos antes mesmo da pergunta ser feita abrindo espaço para a heteronomia.

Segundo Sampaio (2003), a partir desse quadro, Binet e seus colaboradores apresentaram um projeto para a criação das classes especiais, chamadas naquele momento de classes de aperfeiçoamento, que abrigariam alunos que possuíssem uma inteligência superior das crianças asiladas, mas que não tivessem uma inteligência suficiente para acompanhar o ensino regular. Em 1909, é criada a lei para o sistema escolar paralelo, aconselhado para crianças com patologias escolares específicas. Mas devido à resistência dos professores, só após a metade do século que tal sistema foi implantado. O parâmetro de classificação de alunos para ingressarem neste tipo de ensino era realizado pela Escala Métrica da Inteligência de Binet e Simon. Essa maneira de se entender problemas de aprendizagem influenciou a Educação de vários países ao longo do século XX, incluindo o Brasil. 
Cabe aqui lembrar que o principal objetivo da Educação para Adorno é que Aushwitz não se repita. Para isso ocorrer, é necessário desbarbarizar a sociedade. No entanto, as causas geradoras da barbárie são os objetivos e psicológicos já desenvolvidos no capítulo anterior. Os psicológicos são causados pelos inúmeros fracassos experimentados que se convertem em culpa e conseqüentemente em agressividade. Assim, uma atitude que coloca um ser humano em situação de fracasso desde criança pelo simples fato dele não se adequar à norma, é o início de uma vida marcada pela violência, e quanto mais esta atitude é mantida, mais a barbárie se instala no ambiente escolar e mais tarde na sociedade como um todo.

A primeira escola preocupada em solucionar problemas de aprendizagem foi fundada no final do século XIX em Séguin - França - destinada a crianças portadoras de deficiência mental. O trabalho realizado com essas crianças era reeducativo (ARGENTI, 2001). Segundo Rubinstein (2003), neste momento, o aluno ou "sujeito da aprendizagem" não estava presente nas preocupações com a aprendizagem, pois o que se notava eram os distúrbios de aprendizagem e as técnicas que poderiam contribuir para melhorar as condições de aprendizagem, mas o indivíduo, a pessoa que aprende, era deixado em segundo plano. Era um trabalho efetivamente de "natureza adaptativa e denominado de Reeducação Psicopedagógica" (RUBINSTEIN, 2003:21). Esta autora ainda procura fazer uma pequena análise do termo reeducar, ou seja, "educar de novo, ou retomar de outra forma algo que não foi realizado adequadamente" (RUBINSTEIN, 2003:21). Outro nome dado à Reeducação Psicopedagógica foi Psicopedagogia Adaptativa, que procurava segundo Sampaio (2003), desenvolver funções cognitivas através da adaptação do sujeito ao "lugar" que o sistema lhe designou. Aqui temos o outro fator causador da barbárie: o objetivo ou como Adorno denomina - "falência da 
cultura": a falsa promessa de uma cultura pacífica e de que todos os indivíduos são iguais em oportunidades, sendo que na verdade só o são enquanto norma, pois na verdade já possuem seu lugar determinado na sociedade a priori. Segundo o autor, a adaptação tem sua função na sociedade como a transmissão da cultura, por exemplo, e da internalização das regras racionais. Mas uma educação baseada apenas na adaptação, na formação de pessoas bem ajustadas está longe daquilo que o autor defende para uma educação voltada para a democracia. A Psicopedagogia Adaptativa vem em conformidade com a sociedade administrada ${ }^{\mathbf{1 8}}$. Embora o termo usado seja semelhante (adaptação), a proposta de educação de Adorno difere das idéias dos autores adeptos da Psicopedagogia Adaptativa como já discutido no capítulo anterior.

Podemos notar que entre 1890 e 1930, tanto psicólogos como pedagogos e médicos, embora baseados ainda nas noções de inteligência e as idéias contidas em sua definição, havia uma diferença no pressuposto do tratamento desses indivíduos: havia a crença de uma real possibilidade de identificar e promover socialmente os mais aptos, independentemente de sua etnia ou de sua origem social (PATTO, 2000); portanto vemos aí uma maior abertura para entender os problemas de aprendizagem a partir de influências do meio. No entanto, esse meio ainda era visto de maneira "biologizada" e não relacionado com a estrutura social. Vale lembrar que, no entanto, a questão racial ainda predominava nas obras de autores até a metade do século XX. Como dito anteriormente, as explicações para os problemas de aprendizagem durante o século XX vão oscilar nessas duas posições embora ambas com conteúdo revelador de preconceito, onde só é aceito aquele que se enquadra na norma estabelecida. Um exemplo da posição hereditária e que não leva em conta o meio é a de que:

18 “representada pelos oligopólios e permeada pelo princípio da racionalização”.(CROCHIK, 1995:37) 
“Em 1914, nos anais do Congresso de Assistência realizado em Montpellier, os anormais infantis são definidos nos seguintes termos:"aqueles que, sob a influência de taras mórbidas hereditárias ou adquiridas, apresentam defeitos constitucionais de ordem intelectual, caracterial ou moral, associados no mais das vezes a defeitos corporais e capazes de diminuir o poder de adaptação ao meio no qual eles devem viver regularmente"(PATTO, 2000:59).

Aí cabe também outro comentário: além de não levarem em conta os aspectos objetivos nessa análise, com a atitude de promover os mais aptos, estavam no fundo promovendo a barbárie por meio dessa atitude competitiva de que haveria "lugar no céu" apenas para alguns.

No início do século XX, cresceu o número de escolas para ensino destinado a crianças com aprendizagem lenta tanto na Europa como nos EUA (BOSSA, 2000). Na década de 30 na França, surgem os primeiros centros de orientação infantil contando com equipes formadas por médicos, psicólogos, educadores e assistentes sociais.

Após a Segunda Guerra Mundial, Boutonier e Mauco fundaram o primeiro centro médico-psicopedagógico em Paris (1946), com a tentativa de articular Medicina, Psicologia, Psicanálise e Pedagogia com o objetivo de entender e solucionar os problemas de comportamento e aprendizagem escolares (BOSSA, 2000). 
O primeiro enfoque a orientar os psicopedagogos no esclarecimento dos problemas de aprendizagem foi também o orgânico, amparado por uma postura pautada na Biologia e na Medicina como já explicado anteriormente no caso da Psicologia. Pretendiase assim, uma readaptação do aluno por meio da Psicopedagogia. Naquela época, no entanto, esse método adaptativo era chamado de "Pedagogia Curativa", situando-se no interior daquilo que hoje chamam de Psicopedagogia, tendo o objetivo de tratar crianças e adolescentes de inteligência normal, porém, com problemas escolares (Bossa, 2000).

Em 1948, conforme Mery (1985) foi criado em Estrasburgo (França) o segundo Centro Psicopedagógico dirigido também por Boutonier e Mauco. E nesta mesma época foi criada a Associação dos Centros Psicopedagógicos no mesmo país.

Mais tardiamente, embora baseada em idéias já elaboradas na década de 30, a criança deixa de ser considerada "a anormal", que "apresentava problemas de ajustamento" ou "de aprendizagem escolar" para tornar-se "a criança problema". Esse novo termo revela mudanças na concepção das causas das dificuldades de aprendizagem escolar:

\footnotetext{
“(...) se antes elas são decifradas com os instrumentos de uma medicina e de uma psicologia que falam em anormalidades genéticas e orgânicas, agora o são com os instrumentos conceituais da psicologia clínica de inspiração psicanalítica, que buscam no ambiente sócio-familiar as causas dos desajustes infantis... as causas agora vão desde as físicas até as emocionais e de personalidade, passando pelas intelectuais". (PATTO, 2000:62)
} 
Além da inclusão da Psicanálise no tratamento da "criança problema", temos também nessa época as causas dos problemas de aprendizagem atribuídas à cultura: “culturas inferiores ou diferentes" (PATTO, 2000:64). Essas expressões são dotadas de preconceito para justificar as desigualdades promovidas pela própria sociedade.

Na América do Sul, a Psicopedagogia teve principal destaque na Argentina, surgindo há mais de quarenta anos com suas idéias pautadas na literatura francesa. Devido a grande demanda pelo profissional psicopedagogo, criou-se o curso de graduação em 1962 (SAMPAIO, 2003). No entanto, a prática psicopedagógica teve início anteriormente à criação do próprio curso, tendo como objetivo a reeducação de alunos desajustados ao ambiente escolar. Esse é um reflexo direto do nosso tipo de sociedade: a prática, a eficiência e a utilidade como ordem do dia e a teoria, a reflexão em segundo plano. Não é à toa que a Psicopedagogia na Argentina tenha este histórico de primeiro aparecer como prática para depois ser colocada como curso de graduação. Fica a questão: será que é possível uma prática sem uma reflexão prévia? Com certeza que sim, o problema é que esta prática não será necessariamente promotora de emancipação. Sem uma auto-reflexão e sem uma crítica da Educação enquanto colaboradora na produção da cultura da barbárie fica praticamente impossível promover a emancipação uma vez que ela acaba se revelando como reprodução. E mesmo a grande demanda pelo profissional psicopedagogo também é um reflexo desse tipo de educação adaptativa produzida por este tipo de sociedade.

Essa área de conhecimento passou por três momentos diferentes nesse país, em relação ao enfoque dado ao estudo, atendendo a demandas histórico-sociais. Primeiro, com o início em 1956, apresentou ênfase no âmbito pedagógico, estudando processos de 
desenvolvimento, maturidade e aprendizagem humanas, tendo a preocupação com a reeducação. O segundo momento, com início em 1963, procurou estudar medição de funções cognitivas e afetivas. O terceiro momento, a partir de 1978, procurou valorizar a área clínica incluindo diagnóstico e tratamento, abrindo espaço para o campo psicanalítico (BOSSA, 2000). Ou seja, a Psicopedagogia na Argentina acompanhou as idéias relacionadas aos problemas de aprendizagem desenvolvidas na Europa, embora mais tardiamente como podemos observar ao longo desse capítulo: a mesma preocupação de controlar, medir e determinar o destino dos indivíduos desde a escolarização.

As autoras que contribuíram nesta última fase foram Alicia Fernández e Sarah Pain, e que são muito utilizadas no meio acadêmico da Psicopedagogia brasileira atualmente. Na verdade, são autoras muito divulgadas nos cursos de Psicopedagogia brasileiros. Aliás, a Psicopedagogia argentina tem forte influência no desenvolvimento da Psicopedagogia brasileira, por isso sendo importante conhecer um pouco mais sobre seus pressupostos teóricos.

Conforme Argenti (2001), as autoras Sarah Pain e Alicia Fernandez possuem uma visão psicopedagógica mais abrangente em relação aos autores que desenvolveram suas idéias até então, considerando aprendizagem como articulação da inteligência, desejo, corpo e organismo. Essas autoras aproximaram a teoria psicanalítica da Psicopedagogia. Pain (1985) tentou contrapor-se à Psicopedagogia Adaptativa procurando elaborar uma teoria psicopedagógica que permitisse ao aluno com dificuldade de aprendizagem conseguir, a partir de sua marginalização, aprender. E de posse da aprendizagem, deixaria de ser marginalizado e integrar-se-ia à sociedade, de maneira a poder transformá-la. 
Sarah Pain entende aprendizagem como um processo inscrito na dinâmica da transmissão da cultura. Para ela, Educação é a transmissão da cultura e possui quatro funções interdependentes: função mantenedora da educação - relacionada com a transmissão das regras que garantem a partir da adaptação a continuidade da espécie humana; função socializadora da educação - relacionada com a aprendizagem das normas sociais ${ }^{19}$; função repressora da educação - relacionada com a sobrevivência específica do sistema que atua numa sociedade constituindo-se como instrumento de conservação e reprodução das limitações que o poder destina a cada classe e grupo social; função transformadora da educação - relacionada com as contradições do sistema que acabam por produzir mobilizações por parte de grupos situados numa posição de ruptura que se revelam em formas peculiares de expressão revolucionária. "Em resumo, em função do caráter complexo na função educativa a aprendizagem se dá simultaneamente como instância alienante e como possibilidade libertadora" (PAIN, 1985:12).

Adorno não considera essas quatro funções na educação. As funções mantenedora e a socializadora da educação são englobadas numa só: na função adaptativa da educação. Embora ele não ignore a existência da função repressora da educação, não a considera como tendo que existir; pelo contrário, enquanto ela existir, não há como haver emancipação, elas são funções excludentes.

A autora define Psicopedagogia como uma técnica de condução do processo psicológico da aprendizagem, trazendo o cumprimento de ambos os fins educativos:

\footnotetext{
${ }^{19}$ Pain diferencia a socialização que provém da internalização do conjunto de normas pelo superego daquela que possibilita a compreensão ou conscientização de sua origem.
} 


\begin{abstract}
"A psicopedagogia adaptativa, preocupada em fortalecer os processos sintéticos do ego (yo) e facilitar o desenvolvimento das funções cognitivas, pretende colocar o sujeito no lugar em que o sistema lhe designou. Diferentemente, optamos por uma psicopedagogia que permite ao sujeito que não aprende fazer-se cargo de sua marginalização e aprender, a partir da mesma, transformando-se para integrar-se na sociedade, mas dentro da perspectiva da necessidade de transformá-la. Entretanto, o problema de aprendizagem mais grave não é o daquele sujeito que não cumpre a norma estatística, mas sim daquele que constitui a oligotmia social ${ }^{20}$, que produz sujeitos cuja atividade cognitiva pobre, mecânica e passiva, se desenvolve muito aquém daquilo que lhe é estruturalmente possivel”. (PAIN, 1985:12-13)
\end{abstract}

A autora entende e define a Psicopedagogia dentro do esquema regido pela sociedade administrada, ou seja, é criada uma área de conhecimento com fins técnicos, que no fundo é uma técnica - uma prática que conduz ao caminho delineado pelo psicopedagogo. É a idéia do controle, a ilusão de que se pode controlar tudo e todos a partir de uma técnica. É a ilusão do controle que faz o homem acreditar que está se afastando de uma sociedade mítica e cada vez mais próximo de uma sociedade regida pela ciência que controla o incontrolável, que prevê o imprevisível.

Além do mais, Pain fala numa educação voltada para a transformação, mas em nenhum momento diz em que direção deve caminhar essa transformação. A palavra

\footnotetext{
${ }^{20}$ Oligotmia " é a capacidade de aprender e pensar, maciçamente atrapada ${ }^{2}$ por desejo de outras ordens, $e$ oligotimia social que não poderíamos fazer corresponder com nenhuma classe social em particular" (FERNANDEZ, 1991:50).

2 Na tradução do livro de Alicia Fernández - "A inteligência aprisionada" - foi utilizado o termo "aprisionada" no título, por ser o mais próximo do termo espanhol "atrapada". Na verdade, não existe uma tradução para este termo, mas algumas palavras próximas: aprisionada, capturada, bloqueada, enclausurada e encapsulada. Mas por recomendação da autora, a palavra "atrapada" é mantida na obra traduzida com exceção do título.
} 
e o tema transformação são citados, mas não explicados, discutidos e aprofundados. Não há uma preocupação em apontar como seria uma transformação que caminhe em um sentido que não repita a regressão ainda instalada no tipo de sociedade atual.

Segundo a autora (1985), para a aprendizagem ocorrer há dois tipos de condições: externas (estímulos) e as internas (sujeito). A aprendizagem é além de processo, um efeito, um lugar de articulação de esquemas. Nesse "lugar", somam-se um momento histórico, um organismo, uma etapa genética da inteligência e um sujeito epistêmico. Sendo assim, ela estuda a aprendizagem sob três vertentes teóricas: Materialismo Histórico, Epistemologia Genética e a Psicanálise, sendo esta última inaugurada por ela no campo da Psicopedagogia. Ela procura unir três vertentes que partem de princípios diversos e até certo ponto contraditórios. E embora não fale sobre a vertente do Behaviorismo, observa-se que na sua definição de condições externas e internas fica clara a tendência de estímulo e resposta e controle presentes nos condicionamentos operantes do Behaviorismo.

Ela descreve as dimensões da aprendizagem como: dimensão biológica orientada pela formação e coordenação de esquemas, nesse sentido, o conhecimento é algo construído e não inato, sendo o caráter hereditário a própria inteligência; dimensão cognitiva - mais uma vez coordenada pelos esquemas que se transformam de maneira a se adaptar a cada nova realidade que surge; dimensão social - a aprendizagem nesse caso é vista como um dos pólos do processo educativo que compreende os comportamentos dedicados à transmissão da cultura e às instituições que a promovem, como a escola e a família - "através da ação desenvolvida e reprimida o sujeito incorpora na representação do mundo, ao qual por sua vez se 
incorpora e se sujeita" (PAIN, 1985:18). A transmissão da cultura nessa visão é sempre ideológica, selecionando e conservando certos modos de operar, servindo à manutenção das estruturas definidas de poder. E a aprendizagem

\footnotetext{
“Garante a continuidade do processo histórico e a conservação da sociedade como tal, através de suas transformações evolutivas e estruturais. Entretanto, também cumpre um papel relevante na implementação dessas transformações, pois é evidente que se os sistemas estabilizados precisam educar para conservar-se, os revolucionários necessitam educar, com mais razão ainda, a fim de conscientizar a militância" (PAIN, 1985:18).
}

Finalizando as quatro dimensões da aprendizagem, temos o processo de aprendizagem como função do eu (yo) - que é uma função de resignação ou frustração atentando a autores como Freud, Klein e Lacan. Nesse sentido, Pain mostra como o ego não deve ser entendido como um substantivo organizado sob o princípio da realidade, mas ocultando outros princípios próprios. Assim, defende uma aprendizagem voltada ao desconhecido, àquilo que se oculta quando se ensina e ao que se desprende quando se aprende (1985). Aqui temos a influência da psicanálise em suas idéias. Com a inclusão do termo psicanalítico "inconsciente" ela inaugura uma nova modalidade de investigações para os problemas de aprendizagem. No entanto, o conceito de inconsciente aqui é apropriado de uma maneira a somar mais uma instância individual causadora de problemas relacionados ao aprender. E a própria Psicanálise em si só possibilitaria de fato um novo entendimento e ajuda nos assuntos educacionais dessa tarefa se mantivesse sua postura inicial: 


\begin{abstract}
“quando revelava os conflitos existentes e não tentava superá-los dentro do indivíduo, apontando, assim, para uma tensão verdadeira e não suprimível em uma sociedade antagônica. Dessa forma, não é a Psicanálise como um todo que é negada, mas apenas os seus traços adaptativos, além da tentativa do próprio Freud de entender a cultura pelas categorias da psicanálise, o que reforça aqueles traços" (CROCHIK, 1995:45).
\end{abstract}

Problemas de aprendizagem para a autora (1985) são aqueles que atentam para a anormalidade desse processo, independendo do nível cognitivo do indivíduo. "Isto quer dizer que os problemas de aprendizagem são aqueles que se superpõem ao baixo nível intelectual, não permitindo ao sujeito aproveitar as suas possibilidades" (PAIN, 1985:13). Ficam as perguntas: na sociedade em que vivemos atualmente, em que sentido as pessoas aproveitam as suas possibilidades cognitivas? De que maneira a escola trabalha essas possibilidades? Conforme Adorno, o que a escola promove acaba sendo uma pseudoformação, enquanto atenta apenas para a transmissão da cultura de maneira superficial, colaborando para a banalização da mesma e para o enfraquecimento do indivíduo.

Pain acha importante diferenciar os problemas de aprendizagem dos problemas relacionados diretamente à instituição escolar: resistência às normas disciplinares, má integração com o grupo de colegas, desqualificação do professor etc. A autora (1985) considera que esses problemas ocorrem como formação reativa diante da má elaboração na transição do grupo familiar ao grupo social. Nesse caso, ela não indica um tratamento psicopedagógico, mas sim psicoterapêutico familiar 
acompanhado de apoio pedagógico com o objetivo de evitar o fracasso escolar. Aqui, observamos uma tendência a polarizar o problema de aprendizagem no indivíduo que não aprende ou na família ou na escola. É a divisão existente entre Psicopedagogia Clínica e Institucional: ou o problema é interno ou é externo ao aluno. Embora citadas, essas dimensões são analisadas separadamente. Portanto, a pretensão de procurar um espaço além da Psicologia e Pedagogia não se cumpre aqui. E além disso, a análise dos problemas fica sempre polarizada no indivíduo ou no meio, esse entendido como família ou instituição pontual (escolar ou outras). A sociedade promotora das deficiências na área da educação não é comentada.

Ela também se ocupa de diferenciar o papel da Psicopedagogia do papel da Psicologia da Aprendizagem: o psicopedagogo procura construir situações de ensino que possibilitem a aprendizagem, "incrementando os meios, as técnicas e as instruções adequadas para favorecer a correção da dificuldade que o educando apresenta" (PAIN,1985:13). Essa visão é típica da educação compensatória, na qual técnicas e métodos são criados para um certo grupo de pessoas ou para uma pessoa em particular de maneira a compensar uma falta causada pela inadequação dos professores para as diferenças dos alunos. Já o psicólogo se ocuparia dos fatores que determinam o nãoaprender do sujeito e pela significação que a atividade cognitiva tem para ele (PAIN, 1985). Assim, a autora conclui que a Psicopedagogia está voltada para uma intervenção que procura descobrir a "articulação que justifica o sintoma e também para a construção das condições para que o sujeito possa situar-se num lugar tal que o comportamento patológico se torne dispensável" (PAIN, 1985:13). 
Alicia Fernandez é uma autora argentina que baseia sua teoria nas idéias de Sarah Pain. Criou o DIFAJ (diagnóstico interdisciplinar familiar de aprendizagem em uma só jornada) para ser utilizado em instituições como nos hospitais, por exemplo, local onde ela criou essa modalidade de diagnóstico psicopedagógico, com o objetivo de "confluência da interdisciplina, da prevenção, da assistência e da formação" (FERNANDEZ, 1991:15). Aqui se observa mais uma vez a tentativa de ver a Psicopedagogia de forma médica; dessa vez não por tentar procurar um problema físico na pessoa que não aprende, mas na utilização da mesma em instituições hospitalares e do entendimento do problema de aprendizagem como algum tipo de "doença" que precisa ser prevenida. A própria autora chega em diversos trechos de sua obra comparar o problema de aprendizagem com as epidemias. "Nós, os argentinos, temos muitos trágicos exemplos desta patologia, que em alguma época adquiriu o caráter de epidemia” (FERNANDEZ, 1991:50).

Fernandez (1991) diz que a aprendizagem é um processo com uma matriz vincular e lúdica e com raiz corporal; possui quatro níveis de relação entre ensinante e aprendente: orgânico (organismo individual herdado), cognitivo (inteligência construída interacionalmente), corporal (corpo construído especularmente) e afetivo (desejo que é sempre desejo do Outro). Para que ocorra aprendizagem deve haver uma articulação entre inteligência-desejo e do equilíbrio assimilação-acomodação. Esta articulação lembra um ser humano semelhante a uma máquina cujas engrenagens devessem trabalhar articuladas para terem um resultado eficiente. É a automatização do homem. "A aprendizagem é uma das funções para a qual estes níveis podem interrelacionar-se com o exterior e por sua vez conformar-se, a si mesmos, em um processo 
dialético” (FERNANDEZ, 1991:52). Embora não explicite seu referencial teórico, fica subentendido que é o piagetiano e psicanalítico lacaniano.

A aprendizagem além de ser um processo, também aparece como uma função que não se restringe à aprendizagem escolar, mas sim à construção de "um sujeito que vai chegar a ser sujeito, exatamente através da aprendizagem" (FERNANDEZ, 1991:51). "Não aprendemos de qualquer um, aprendemos daquele a quem outorgamos confiança e direito de ensinar" (FERNANDEZ, 1991:52).

Para a autora, o fracasso no aprender está muitas vezes relacionado aos vínculos formados pelo grupo familiar e mantidos pela instituição escolar. "A criança pode não aprender, assumindo o medo de conhecer e de saber da família, ou respondendo à marginalização sócio-educativa” (FERNANDEZ, 1991:48).

O não aprender pode ser entendido como proveniente de: fatores internos ao grupo familiar e ao paciente ("problema de aprendizagem sintoma") ou fatores de ordem educativa como os relacionados com a instituição educativa ("problema de aprendizagem reativo"). Dentro da modalidade de problema de aprendizagem sintoma temos a inibição cognitiva que se diferencia do sintoma pela diminuição, evitação ao contato com o objeto do pensamento, enquanto que no sintoma encontramos transformação, condensação e deslocamentos do mesmo. Na inibição ocorre o que a autora denomina de aprendizagem hipoassimilatória/ hipoacomodatória. No sintoma, a modalidade de aprendizagem se desequilibra apresentando-se como 
hiperassimilação/ hiperacomodação ${ }^{\mathbf{2 1}}$ ou hipoassimilação /hiperacomodação. Assim como Pain, essa autora também polariza o problema de aprendizagem sendo interno ou externo ao indivíduo - indivíduo/instituição - acabando por mostrar que a Psicopedagogia não cumpre sua função de preencher o espaço entre a Psicologia e a Pedagogia. Os aspectos sociais são desconsiderados no que tange a estrutura social e o meio mais uma vez entendido como estímulos do ambiente. E mais uma vez como podemos observar na citação abaixo, o problema de aprendizagem é visto como uma doença, aproximando a Psicopedagogia de uma prática médica.

\footnotetext{
“A diferença entre sintoma e problema de aprendizagem reativo é comparável à diferença existente entre desnutrição e anorexia. O anoréxico não come, o desnutrido tampouco, mas a articulação do não comer em um caso, é totalmente diferente do outro. No anoréxico poderíamos dizer que houve um atrape do comer, por desejos de ordem inconsciente, pelo que, apesar de ter comida, não come. Enquanto que na desnutrição, o desejo de comer está ou esteve presente, o que falta é a comida” (FERNANDEZ, 1991:83).
}

Há ainda a "oligotimia social” já citada e explicada anteriormente. Nesse caso, ela se refere aos indivíduos que não aprendem por causa da falta de estímulos apresentados em certos meios, na maior parte das vezes os sócio econômicos mais baixos. Ela conclui

\footnotetext{
21 Termos criados por Sarah Pain e utilizados por Alicia Fernandez para indicar modalidades de aprendizagem:

"Hipoassimilação - pobreza de contato com o objeto que redunda em esquemas de objetos empobrecidos, déficit lúdico e criativo;

Hiperacomodação - pobreza de contato com a subjetividade, superestimulação da imitação, falta de iniciativa, obediência acrítica às normas, submissão.

Hipoacomodação - pobreza de contato com o objeto, dificuldade na internalização de imagens, a criança sofreu a falta de estimulação ou o abandono;

Hiperassimilação - predomínio da subetivação, desrealização do pensamento, dificuldade para resignarse." (FERNANDEZ, 1991:110)
} 
que essas pessoas não possuem só a instância econômica em seus problemas e que, dizer que apenas essas crianças teriam problemas de aprendizagem, seria uma conclusão apressada e errônea. Elas possuem também um inconsciente, organismo e inteligência e relata experiências realizadas no Rio Grande do Sul no Brasil, que revelaram como pessoas de classes econômicas desfavorecidas podem aprender também, através de uma mudança ideológica por parte dos educadores e da instituição, a partir da mudança da metodologia, como a linguagem utilizada com a criança, respeitando sua marginalização. Nesse caso, " $a$ intervenção terapêutica psicopedagógica torna-se inapropriada para abordar a oligotimia social que muitas vezes pode funcionar como reafirmação do sistema, se o psicopedagogo torna-se ingenuamente cúmplice desta situação ao errar no diagnóstico" (FERNANDEZ, 1991:83). Aqui vemos uma primeira preocupação em tentar relacionar o fracasso escolar com o social, olhar o fracasso escolar de maneira critica, mas acaba por fazer uma análise baseada na "teoria da carência cultural 22", procurando explicar o fracasso dos alunos de classe econômica desfavorecida com argumentos de teorias interacionistas do desenvolvimento humano. O meio social é visto de uma maneira acrítica e "biologizada". Trata-se de uma forma preconceituosa de enxergar a pobreza tomando como padrão a forma de viver da classe dominante. "O único critério para se distinguir o normal do patológico é dado por aquilo que a cultura exige, a cada momento, de seus membros e pelas respostas destes a essas exigências" (CROCHIK, 1997: 33). Como solução procuram adotar programas de educação compensatória de maneira a tentar igualar os pobres aos pertencentes à classe dominante. A teoria da carência cultural aliada à educação compensatória como medida de resolução para o fracasso escolar de crianças de classes

\footnotetext{
${ }^{22}$ A Teoria da Carência Cultural é definida como uma teoria dotada de um preconceito disfarçado em relação às populações menos favorecidas economicamente. “...Pelo recurso a versões ambientalistas do desenvolvimento, reservando-se ao termo ambiente uma concepção acrítica, compatível ao mesmo tempo com uma visão biologizada da vida social e com uma definição etnocêntrica de cultura: de um lado o ambiente é praticamente reduzido a estimulação sensorial proveniente do meio físico; de outro, valores, crenças, normas, hábitos e habilidades tidos como típicos das classes dominantes são considerados como os mais adequados à promoção de um desenvolvimento psicológico sadio" (PATTO, 2000: 67-68).
} 
econômicas desfavorecidas é outra fonte reveladora de preconceito: "ao minimizar o erro do aluno ou ao tornar o conteúdo palatável com aquilo que se julga que o aluno possa aprender, dirigem-se à sua suposta incompetência: tanto de enfrentar o sofrimento e ser capaz de superá-lo, como de compreender aquilo que lhe é dito" (CROCHIK, 1997:123). Essa subestimação para Adorno contribui para uma maior confusão em relação ao entendimento da realidade contribuindo para a percepção do mundo a partir de estereótipos.

É importante também entender de que maneira essa autora se apropria do termo inconsciente, mais uma vez como uma entidade pertencente ao indivíduo, eliminando a tensão existente com a sociedade, revelando problemas deste indivíduo em sua relação com a família, escola e demais instituições. No entanto, independentemente da instituição na qual ele se relaciona, o problema fica localizado nele. Mesmo que esse Inconsciente não possa ser passível de controle, ainda assim ele fica relacionado ao indivíduo que o possui. Sendo assim, ele deve ser submetido a algum tipo de atendimento seja clínico ou institucional de maneira a procurar obter melhoras no aproveitamento escolar.

Acrescenta que a tarefa do psicopedagogo é ajudar o paciente a recuperar o prazer de aprender, pois para ela, a inteligência se torna aprisionada porque perdeu-se o prazer na aprendizagem; só pela recuperação desse prazer que é possível recuperá-la. Esta tentativa de evitar a frustração do aluno, de forma a não evitar um desprazer na aprendizagem pode estar colaborando para que o aluno não perceba seus próprios limites e tente superá-los. 


\begin{abstract}
"Deve-se lembrar que Freud mostra a infantilização que acarreta a não percepção do sofrimento que a realidade nos causa e a conseqüente impotência que é suscitada para enfrentá-lo. Se a realidade é iludida,o indivíduo encontra dificuldades de perceber o que deve enfrentar par tornar-se melhor do que é” (CROCHIK, 1997:123).
\end{abstract}

Para Fernandez (1991), o psicopedagogo deve ainda conduzir planos de prevenção nas escolas ou intervir mais diretamente fornecendo indicações e acessoria em escolas, indicação de mudança de instituição quando o aluno nela não se enquadra, orientação e ajuda extra-escolar, fornecendo espaço extra escolar etc.

No Brasil, a explicação dos problemas de aprendizagem também tem início com justificativas baseadas em fatores orgânicos. As idéias vindas da Europa influenciaram fortemente a Psicologia e a Educação no Brasil. Por conseguinte, influenciaram a Psicopedagogia também, filtradas por autores argentinos. Aproximadamente na metade do século XX, a abordagem utilizada na Psicopedagogia era basicamente a psiconeurológica do desenvolvimento humano, muito difundida em nosso país naquele momento (SCOZ, 1991). Problemas de aprendizagem como afasias, dislexias, disgrafias ou conceitos como o de "Disfunção Cerebral Mínima" apontavam para essa visão orgânica (ARGENTI, 2001).

Essa abordagem médica que possui um lugar de importância na Psicopedagogia tem suas raízes na Psicologia Educacional assim como na Psicologia: "Os primeiros trabalhos brasileiros de interesse psicológico foram teses de conclusão de curso nas faculdades de medicina da Bahia e do Rio de Janeiro, ainda na primeira 
metade do século passado 23 ", (PATTO, 2000:100). Segundo a autora, Arthur Ramos foi o primeiro médico que viria a contribuir de maneira decisiva para o desenvolvimento da psicologia educacional no Brasil preocupando-se com uma educação voltada para a higiene mental. Data de 1934 "a primeira experiência brasileira de instalação de clínicas de higiene mental, nas escolas, articuladas com a tarefa pedagógica" (PATTO, 2000:105). Para Ramos, os aspectos orgânicos vinham em destaque para explicar as causas dos problemas de aprendizagem. Vale lembrar que nessa época já havia força as idéias da psicanálise, mas ainda assim aqui no Brasil outras idéias prevaleciam sobre a mesma:

\footnotetext{
"Coerente com uma formação médica realizada no início do século, Ramos por vezes se esquecia das lições da psicanálise e enfatizava a importância das causas físicas no estudo dos casos de fracasso escolar: ...ao lado da classificação, para fins pedagógicos, do escolar (através de testes de QI), se tornam necessários exames complementares, de caráter médico-orgânico, uma disfunção glandular, um transtorno neuropsíquico qualitativo etc, que por força influirão na apreciação do simples quociente intelectual”" (PATTO, 2000:109).
}

Os primeiro psicólogos eram médicos e os que não eram médicos foram formados por esses profissionais que começaram a lecionar nas escolas normais, em cursos de graduação em psicologia e de especialização na mesma área nas faculdades de filosofia.

\footnotetext{
${ }^{23}$ Século XIX
} 
Foi da associação entre os pensamentos da Medicina e da Psicanálise e da atuação desses profissionais que surgiram as primeiras clínicas de tratamento de problemas educacionais.

\footnotetext{
“alguns desses médicos-psicólogos realizaram uma trajetória institucional decisiva para os rumos que a explicação do insucesso escolar e o tratamento que passou a ser-lhe dispensado tomaram nas décadas seguintes: dos hospitais psiquiátricos para os institutos, ligas e clínicas de higiene mental, destes para os serviços de inspeção médico-escolar, destes para as clínicas de orientação infantil estatais e destas para os departamentos de assistência ao escolar de secretarias da educação, onde se tornaram coordenadores de equipes multidisciplinares de atendimento ao escolar" (PATTO, 2000:102).
}

A Medicina influenciou o pensamento educacional contribuindo para a difusão das teorias baseadas em concepções racistas de comportamento humano e da vida social desde a passagem do século XIX para o XX como já apontado no início do capítulo, mas aqui lembrando que esse ideário teve influência também no Brasil, mesmo que posteriormente. O problema nesse tipo de concepção não é necessariamente considerar orgânico/físico o problema escolar, mas utilizar desse argumento para não considerar o tipo de sociedade em que vivemos e sendo assim, considerar individual aquilo que é social. É a teoria sendo usada para fins regressivos, reafirmando o status quo.

Não é à toa que a Psicopedagogia possui nessa época suas bases nos fatores orgânicos/biológicos/físicos. Vale lembrar que a época em que a Psicopedagogia tem início no Brasil (por volta da metade do século passado), a Educação era influenciada pelo 
ideário da Escola Nova, considerada uma teoria educacional não crítica ${ }^{24}$ segundo Saviani (1999). A Escola Nova surge no Brasil a partir de 1920 e consolida-se na década de 30. Esta teoria procurava basear-se em conceitos da Psicologia e Biologia. Tinha como princípio a escola sendo um instrumento de equalização social, na qual o marginalizado deixa de ser o ignorante para ser o diferente. A aprendizagem para ocorrer depende do ambiente estimulador. Além do custo elevado que ela exigia, acabou por rebaixar o ensino às classes populares como maneira de compensar as diferenças dos marginalizados.

Entre 1938 e 1956, foi criado o INEP (Centro Brasileiro de Pesquisa Educacional) e dos seus centros regionais, respectivamente, predominaram, segundo Patto (2000), as pesquisas de natureza psicopedagógica, em perfeita consonância com a visão do processo ensino-aprendizagem que resultou do encontro entre a Pedagogia e a Psicologia na constituição do pensamento escolanovista.

Na segunda metade da década de 60, havia dois tipos de trabalho psicopedagógico: um ligado à parte corporal realizado pelos psicomotricistas e outro que procurava trabalhar linguagem oral, audição, voz, leitura e escrita (Bossa, 2000). Acreditavam que por meio da estimulação do meio, os problemas de aprendizagem poderiam diminuir. Estimulações constantes e sucessivas eram a solução para os problemas de aprendizagem causados por problemas motores. Embora entendessem que tais problemas não fossem gerados por causas somente hereditárias, mas considerando a colaboração do meio como fator determinante na aprendizagem, ou seja, mesmo com a inauguração de uma abordagem interacionista dos problemas de aprendizagem, ainda

\footnotetext{
${ }^{24}$ Trata-se de teorias que entendem ser a educação um instrumento de equalização social, de superação da marginalidade. Nesse caso, a educação tem grande autonomia em relação à sociedade. Cabe a ela o papel decisivo na conformação da sociedade, evitando um desagregação e garantindo a construção de uma sociedade igualitária. Há um reconhecimento apenas da atuação da educação sobre a sociedade e um desconhecimento das determinações sociais do fenômeno educativo (SAVIANI, 1999).
} 
assim os preconceitos raciais e sociais permaneciam: os problemas de aprendizagem eram adquiridos fora do ambiente escolar (PATTO, 2000).

De 1965 a 1970 ainda seguindo a mesma concepção comentada no parágrafo anterior, Gouveia comentada por Patto (2000) identifica o predomínio, sobretudo nas universidades e na produção acadêmica de psicólogos e pedagogos, de estudos psicopedagógicos, visando na maior parte das vezes, "a pesquisa de instrumentos de medida psicológica, especialmente de habilidades específicas, tendo em vista aplicálos no esclarecimento das causas das dificuldades de aprendizagem escolar" (PATTO, 2000:137).

Arthur Ramos era adepto das idéias da literatura internacional que traziam a expressão "criança problema”, já comentada anteriormente, que tinha embutido o conceito de desajustamento e com objetivo de correção de desvios. Nesse conceito também vinha a idéia da ação do meio como causador dos problemas de aprendizagem. Não só para esse autor como os adeptos de suas idéias, meio era sinônimo principalmente de ambiente familiar (PATTO, 2000).

Na década de 70, aparece uma outra modalidade de trabalho, o preventivo, com o objetivo de evitar que os alunos precisassem freqüentar clínicas pelo fato de apresentarem problemas de desajustamento escolar. Conforme Fernández (1991), comentada por Argenti (2001:32), se existisse uma educação baseada na prevenção, que "realmente representasse uma modalidade de transmissão da cultura", a maior parte dos problemas de aprendizagem deixaria de existir. 
Segundo Argenti (2001), no início desta década, Spieker apresentou no Congresso Brasileiro de Psicopatologia Infanto-Juvenil a importância de "buscar uma compreensão psicanalítica para poder embasar as estratégias de intervenção junto ao sujeito, portador de problema de aprendizagem, e ainda, a necessidade de se realizar trabalho especifico com a família deste...” (SPIEKER apud ARGENTI, 2001:25). Há uma preocupação em relacionar o não aprender com o Inconsciente da psicanálise de maneira a alterar a avaliação da aprendizagem como um problema exclusivamente orgânico. Aqui o Inconsciente também é visto como uma entidade individual que revela problemas emocionais relativos a este sujeito ou na interação desse com sua família ou escola. A apropriação desse termo é feita de maneira a anular a tensão indivíduo-sociedade.

Essa década também foi influenciada pelas idéias da teoria da carência cultural, evidenciada por uma alta correlação positiva entre classe social e escolaridade.

Os anos 80 na educação brasileira foram marcados pelo aumento do número de vagas nas escolas, no entanto, a qualidade do ensino oferecida por essas escolas não foi o mesmo. A evasão e a repetência aumentaram nessa época sendo o Brasil colocado como $106^{\circ}$ em evasão escolar no primeiro grau. Dessas crianças que repetem ou evadem, a maior parte estuda em escolas públicas das redes estadual e municipal de educação, coincidindo com as camadas mais pobres da população (SOUZA, 1997).

Na Psicopedagogia, a partir dessa década, embora ainda havendo a ênfase na prevenção dos problemas de aprendizagem levando em consideração esse aumento abusivo dos números de evasão e repetência, outro ponto trabalhado diz respeito a pesquisas direcionadas ao estudo da aprendizagem como um todo, ou seja, não apenas a 
aprendizagem do aluno, mas de que maneira se dá a aprendizagem dos professores também, considerando que são parte ativa do processo de ensino (RUBINSTEIN, 1987). Parte-se da hipótese que um professor que tenha uma "boa relação" com a aprendizagem, por conseguinte, formará alunos que também terão uma boa relação com o aprender. Da mesma forma, um professor que não se relacione bem com o aprender também passará este modelo para seus alunos.

Essa idéia de fracasso escolar que inclui não só os alunos, seus problemas e mais os dos professores e da escola enquanto instituição, embora instalada no Brasil só nos anos 80, tem suas origens nas idéias higienistas, segundo a qual, não só alunos, mas professores e a escola como um todo deveria ser higienizada mentalmente "falava-se em higiene mental escolar e não do escolar. (...)Assim como nas clínicas ortofrênicas o tratamento deveria abranger filhos e "pais problemas", no ambiente escolar a higiene mental do professor era tida como condição necessária ao bom encaminhamento do processo educativo” (PATTO, 2000:107). Arthur Ramos referiase a "professores problemas", ou seja, não só os alunos, mas os professores também poderiam ser portadores de distúrbios de personalidade e concluía:

\footnotetext{
"A higiene mental do professor é hoje uma fase indispensável num serviço de higiene mental escolar. Desta perspectiva, o comportamento do professor na relação com o aluno era tido como conseqüencia de seus problemas emocionais familiares atuais ou passados: ora o professor estava projetando nos alunos seus próprios complexos, refletindo nesta relação os desajustamentos emocionais, conjugais, econômicos, sociais de seu ambiente doméstico, ora repetindo no trato com as crianças suas próprias
} 
experiências decorrentes de uma educação equivocada ou sofrida"

(PATTO, 2000:107)

Quanto à existência de cursos de Psicopedagogia no Brasil, temos em 1954, o primeiro registro de um "Curso de Orientação Psicopedagógica", com o objetivo de oferecer atendimento a crianças excepcionais (Bossa, 2000).

Mais tarde, em 1967, aparece um curso com um enfoque relacionado ao trabalho da leitura e escrita.

Ao final da década de 70, surgem os primeiros cursos de especialização em Psicopedagogia no Brasil. Foram "idealizados para complementar a formação dos psicólogos e educadores que buscavam soluções para esses problemas" relacionados à aprendizagem (Bossa, 2000:51). Voltava-se para uma atuação clínica com um enfoque reeducativo. Em seguida, o curso adquire um caráter terapêutico e preventivo. Atualmente há uma preocupação com a identidade do profissional psicopedagogo na distinção entre o perfil clínico e o institucional (Bossa, 2000). Além disso, há a contribuição da Sociolinguiística e da Psicolingüística, consideradas novas abordagens teóricas sobre a aprendizagem e desenvolvimento, estudos sobre fatores intra e extra escolares na determinação do fracasso escolar (SCOZ, 1991).

Segundo Argenti (2001), atualmente a Psicopedagogia procura trabalhar com o objetivo que as pessoas consigam obter qualidade em suas relações com o conhecimento. Para isso, as abordagens clínica e institucional devem ser entendidas como inter- 
relacionadas e interdependentes, uma vez que ambas abordagens não se contrapõem, mas se complementam. A abordagem clínica $^{\mathbf{2 5}}$ consiste na intervenção terapêutica psicopedagógica sobre a pessoa que não aprende por motivos individuais ou familiares, podendo ter seu problema de aprendizagem diagnosticado como sintoma ou inibição. $\mathrm{O}$ sintoma ou inibição causam um "aprisionamento" da inteligência do indivíduo que não aprende, a partir da estrutura simbólica inconsciente (FERNÁNDEZ, 1991). Neste caso, o procedimento envolve um diagnóstico, atendimentos terapêuticos, contratos com a família e escola do cliente. A abordagem institucional ${ }^{\mathbf{2 6}}$ ou preventiva tem seu foco na instituição de ensino e o problema de aprendizagem dos alunos quando a deficiência está na instituição é reativo uma vez que não lhe pertence diretamente. O trabalho é realizado principalmente sobre os profissionais envolvidos na prática educativa da escola, e desta forma, o aluno é atendido indiretamente. Este trabalho deve propiciar reflexões, observações e transformações em relação à maneira que cada um entende o conhecimento, com o objetivo de transformar a escola em um lugar de construção de conhecimento (FERNÁNDEZ, 1991). Não é comentado, no entanto, como deve se dar esta transformação, em qual direção deve caminhar o conhecimento.

A Psicopedagogia conta atualmente com a Associação Brasileira de Psicopedagogia (ABPp) desde 1988, iniciada em 1980 em São Paulo como Associação de Psicopedagogos de São Paulo. A ABPp divide o papel do psicopedagogo em duas polaridades:

\footnotetext{
${ }^{25}$ O livro "A inteligência aprisionada" de Alicia Fernández trata da Psicopedagogia em um modelo de abordagem clínica de maneira detalhada. O pensamento de Fernández foi desenvolvido dentro desse capítulo que estamos tratando.

${ }^{26}$ A autora Neide Noffs possui mais de uma obra que trata especificamente da abordagem psicopedagógica Institucional de uma maneira mais detalhada. Inclusive, a tese de doutorado dela está incluída no material analisado nesta pesquisa.
} 


\begin{abstract}
"Transmissão de conhecimento e compreensão dos fatores psicológicos que interferem no ato de aprender: deve levar em conta o papel da família como transmissor de cultura e, acima de tudo como matriz dos primeiros modelos de aprendizagem; reconhecer a escola como um espaço para o sujeito adquirir conhecimentos e transformálos num "saber"; considerar a instituição hospitalar como elemento fundamental na realização de diagnósticos multidisciplinares para a identificação de dificuldades de aprendizagem; favorecer a aprendizagem do sujeito ao assumir novas funções em seu contexto de trabalho" (MENDES, 1994:16-17).
\end{abstract}

Aqui se fala em transmissão de conhecimento, mas não se fala em reflexão sobre esse conhecimento, de qual maneira ele deve ser apresentado, como mera informação ou seguido de uma reflexão crítica. Nesse papel do psicopedagogo também não se fala a respeito dos conteúdos pertencentes à Psicopedagogia: se deve ou não realizar constantemente uma crítica sobre o próprio pensamento psicopedagógico. Fala-se em família, hospital e escola como sinônimos de meio mas não se considera a estrutura social como meio determinante na aprendizagem e responsável pelo fracasso escolar.

Atualmente, há uma luta dos psicopedagogos para tornarem a Psicopedagogia uma profissão, ou seja, efetivar seu espaço no mercado de trabalho. Há a existência do projeto de Lei $\mathrm{n}^{\circ} 3.124 / 97$ elaborado pelo deputado Barbosa Neto, "que regulamenta a profissão de Psicopedagogo e cria o Conselho Federal e os Conselhos Regionais de Psicopedagogia” (BOSSA, 2000:73). Nesse projeto define o papel do psicopedagogo:

\footnotetext{
"Psicopedagogo é o profissional que auxilia na identificação e resolução dos problemas no processo de aprender. O Psicopedagogo está
} 
capacitado a lidar com as dificuldades de aprendizagem, um dos fatores que leva à multirepetência e à evasão escolar, conduzindo à marginalização social. Este profissional detêm um corpo de conhecimentos científicos oriundos da articulação de várias áreas aliado a uma prática clínica elou institucional que considera a multiplicidade de fatores que interferem na aprendizagem" (NETO apud BOSSA, 2000:73).

Como podemos observar, embora a Psicopedagogia venha passando por diversos percursos, tanto na Argentina como no Brasil, ela se propõe a compreender o processo referente às dificuldades de aprendizagem escolar e com a tentativa de transformar a realidade educacional, procurando reunir diversas áreas do conhecimento em uma só, acreditando que poderá, assim, cobrir as lacunas deixadas por elas, principalmente pela Psicologia e Pedagogia:

“A Psicopedagogia se ocupa da aprendizagem humana, que adveio de uma demanda - o problema de aprendizagem, colocado num território pouco explorado, situado além dos limites da Psicologia e da própria Pedagogia... constituindo-se assim, numa prática. Como se preocupa com o problema de aprendizagem, deve ocupar-se inicialmente do processo de aprendizagem” (Bossa, 2000:21).

Bossa nessa citação tenta definir a Psicopedagogia como uma área independente da Psicologia e da Pedagogia, mas com tudo o que vimos sobre o desenvolvimento das idéias psicopedagógicas, ela acaba não ocupando este espaço "além da Psicologia e Pedagogia" mas repetindo as duas polaridades através das 
modalidades clínica e institucional, ou seja, o problema se encontra no aluno ou fora dele assim como as idéias defendidas pela Psicologia e Pedagogia do século passado, além de não levar em conta em nenhum momento os determinantes sociais. 
- Capítulo 3 -

Método 


\section{Método}

\subsection{Material:}

O material utilizado para a realização deste trabalho de pesquisa foram as dissertações e teses especificadas no CD ROM intitulado "ANPED 99: teses, dissertações e artigos de periódicos", compreendendo os anos de 1981 a 1998, e as dissertações e teses obtidas nos programas de pós-graduação de Psicologia e Educação da USP-capital e PUCSP, compreendidas entre os anos de 1981 e 2001. O CD ROM contem os resumos de publicações de dissertações e teses defendidas entre os anos de 1981 e 1998 no Brasil e 20 artigos de periódicos nacionais na área da Educação nos anos de 1996 a 1998; para este trabalho serão utilizadas somente as dissertações e teses contendo o descritor Psicopedagogia. O CD ROM e as teses e dissertações dos programas de Psicologia e Educação da PUC-SP foram obtidos na biblioteca Nadir Gouvêa Kfouri localizada na Pontifícia Universidade Católica (PUC) de São Paulo, por meio do banco de dados "Lúmen", que compreende os acervos do Sistema de Bibliotecas da PUC-SP. As dissertações e teses do programa de pós-graduação em Psicologia da USP-capital foram retiradas da biblioteca do Instituto de Psicologia da USP e os trabalhos do programa de pós-graduação em Educação da USP-capital foram retirados da biblioteca da Faculdade de Educação da USP, por meio do sistema de computação "Dedalus" que realiza consultas de base de dados de ambas bibliotecas. O CD ROM contemplou o período de 1981 a 1998 referente aos trabalhos publicados no Brasil. As dissertações e teses dos programas de pósgraduação de Educação e Psicologia da USP e PUC compreenderam além deste período (1981-1998), os anos de 1999 a 2001, no entanto, apenas compreendendo trabalhos publicados na cidade de São Paulo. 


\subsection{Procedimento:}

O procedimento se dividiu em quatro etapas.

$\underline{1^{a} \text { etapa: }}$ foi utilizado o programa do CD ROM da ANPED; digitou-se o descritor "Psicopedagogia", de forma a selecionar todas as dissertações e teses defendidas nesse período e referentes a tal assunto. De posse dos resumos e de uma leitura dos mesmos, foi feito o levantamento de alguns dados pertinentes à pesquisa como: os outros descritores relacionados nesses trabalhos, ano de publicação, local, temas ou assuntos abordados e a concepção de Psicopedagogia entendida nessas obras, quando possível.

Foram encontrados 201 trabalhos no CD ROM referentes ao descritor “psicopedagogia". No entanto, dentre esses trabalhos, 10 são artigos de periódicos e, portanto, os demais, que são as dissertações e teses encontradas neste CD ROM, somam 191 no total. Esses 191 trabalhos contendo o descritor "psicopedagogia" coincidiram com as 191 dissertações e teses apresentadas quando digitados os descritores Psicologia da Educação e Psicologia Escolar, portanto, apontando imediatamente para uma indiferenciação entre essas três expressões.

Outro fato observado foi que na maior parte das obras (172 das 191 encontradas), o termo "Psicopedagogia" foi utilizado de uma maneira muito ampla e diversa, podendo ser englobado em diversos tipos de assuntos que envolvem as áreas de conhecimento relacionadas à Educação, Psicologia da Educação, Psicologia Escolar ou ainda na relação entre Psicologia e Educação, o que mostra mais uma vez a indiferenciação da área. Foram escolhidas, então, as 19 obras, nas quais o termo "Psicopedagogia" aparece explicitamente no título do trabalho e/ou em seu resumo. 
Portanto, o critério de seleção de teses e dissertações para serem utilizadas nesta pesquisa foi o termo "Psicopedagogia" e palavras derivadas como “psicopedagógico(a)(s)”, “psicopedagogo(a)(s)" aparecerem evidenciadas no título do trabalho e/ou em seu resumo.

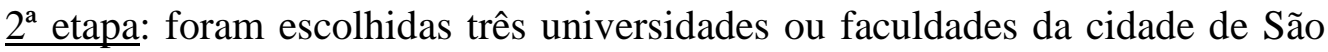
Paulo. Uma delas deveria ser pública, outra particular e outra confessional, todas devendo ter programas de pós-graduação em Psicologia e Educação. A universidade pública escolhida foi a Universidade de São Paulo (USP) e a confessional foi a Pontifícia Universidade Católica (PUC). No entanto, não foi possível eleger uma universidade ou faculdade particular, pois das sete escolas pesquisadas, nenhuma delas apresentou simultaneamente pós-graduação stritu sensu em Psicologia e Educação. As universidades investigadas foram: FMU, UNIP, UNISA, UNINOVE, FAAP, UNIBAN e UNICID. Apenas a UNICID, UNIBAN e UNINOVE apresentam somente mestrado na área de Educação e ainda assim, este é um curso recente nessas universidades não abrangendo os anos selecionados para esta pesquisa. Em nenhuma delas foi encontrado o curso de pós-graduação stritu sensu em Psicologia.

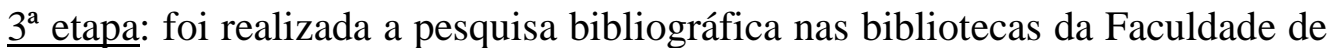
Educação da USP, Instituto de Psicologia da USP e da PUC-SP, utilizando o mesmo sistema de pesquisa via computador localizado dentro dessas bibliotecas "Dedalus" e "Lúmen" respectivamente. Foram selecionadas todas as dissertações e teses contendo o descritor "psicopedagogia" como palavra-chave ou assunto compreendidas no período referente a 1981 e 2001, e que tivessem sido defendidas nos programas de pósgraduação em Psicologia ou Educação. Após esta pesquisa, foi realizado o mesmo 
procedimento utilizado com os trabalhos coletados no CD ROM da ANPED. Nessa segunda pesquisa foram obtidos 12 trabalhos nos programas de Psicologia (sendo que um deles é uma tese de livre-docência) e 39 trabalhos nos programas de Educação, somando 51. No entanto, foi observado que, nessa nova pesquisa, alguns trabalhos encontrados nos programas de pós-graduação da Educação da PUC e USP já haviam aparecido na pesquisa realizada com o CD ROM da ANPED. Isto ocorreu com uma dissertação e três teses da PUC e duas dissertações e uma tese da USP; portanto, considerando trabalhos que ainda não tinham sido selecionados antes, foram encontrados nove na USP (incluindo a tese de livre-docência) e 35 na PUC, 44 no total. Dos trabalhos (contando novamente aqueles que se repetem nas duas pesquisas bibliográficas), foram selecionados (segundo o mesmo critério anterior) seis da área da Psicologia e seis da área de Educação, totalizando 12 trabalhos. Como já foi dito anteriormente, alguns trabalhos se repetiram nas duas pesquisas bibliográficas. Dentre esses trabalhos repetidos, duas dissertações e uma tese da USP estavam nas demais que tinham sido selecionadas para esse trabalho de pesquisa pelo CD ROM da ANPED e os trabalhos da PUC que se repetiam, não foram selecionados nenhum deles para a pesquisa. Portanto, dos 12 trabalhos selecionados, três deles do programa de pósgraduação da Educação (USP) já havia sido escolhido na primeira etapa do procedimento.

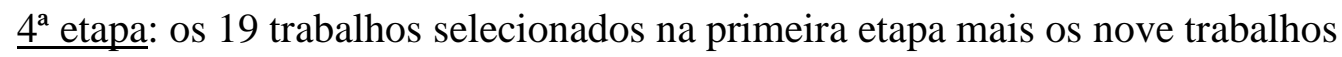
da segunda (eram 12 trabalhos, porém três se repetem como foi dito anteriormente), foram analisados mais aprofundadamente. Foi feita uma leitura não só do resumo das obras, mas de sua íntegra. Foram caracterizadas segundo os seguintes pontos: 
- ano de publicação;

- local de publicação;

- concepções de Psicopedagogia;

- objetivos do trabalho;

- tipo de pesquisa;

- referencial teórico/autores;

- conclusões;

e sua relação com os termos adaptação-emancipação conforme são definidos pela Teoria Crítica da Sociedade.

Os títulos e descrições das 28 dissertações e teses selecionadas encontram-se em anexo. Dentre elas, quatro não foram encontradas disponíveis para consulta e leitura nas respectivas bibliotecas. Portanto, foram analisados os 24 trabalhos restantes.

3.3 Forma de análise dos resultados:

Como foi apontado anteriormente, o termo "Psicopedagogia" aparece de uma maneira mais diferenciada e evidenciada no título dos trabalhos ou resumos dos mesmos em 19 obras retiradas do CD ROM da ANPED e em nove da pesquisa realizada exclusivamente na PUC e USP. A partir da leitura dessas obras, foram analisados e discriminados os itens descritos anteriormente. 
Para organizar esses dados foram feitos registros (modelo em anexo) contendo os itens acima e apresentadas tabelas sobre os mesmos, incluindo os 25 trabalhos (três trabalhos não foram encontrados) em cada um deles.

Vale lembrar que a tabulação dos dados obtidos foi feita separadamente para as dissertações e teses contidas no CD ROM da ANPED e para a pesquisa realizada exclusivamente nas Universidades PUC-SP e USP.

Simultaneamente, será realizada uma reflexão procurando apontar as concepções de Psicopedagogia enquanto área de conhecimento, relacionando-as com os termos educação para a adaptação-emancipação, que são conceitos elaborados por Adorno e que são considerados pelo autor como essenciais para a Educação. 


$$
\text { - Capítulo } 4 \text { - }
$$

\section{Apresentação dos resultados}




\section{Apresentação dos Resultados}

Este capítulo tem como objetivos apresentar os resultados obtidos na pesquisa com o CD ROM “ANPED 99: teses, dissertações e artigos de periódicos” (1999) e com as dissertações e teses dos programas de Pós-graduação dos cursos de Educação e Psicologia da USP-SP e PUC-SP.

Inicialmente iremos apresentar as tabelas referentes às dissertações e teses que possuem o descritor "psicopedagogia" contidas no CD ROM da ANPED; a seguir as tabelas referentes aos trabalhos selecionados para a presente pesquisa obtidos no $C D$ ROM da ANPED; depois, os trabalhos obtidos na pesquisa realizada na USP-SP e PUC-SP (cursos de Pós-graduação em Psicologia e Educação) contendo o descritor "psicopedagogia"; finalmente, os trabalhos escolhidos para a presente pesquisa encontrados na PUC-SP e USP-SP.

É importante lembrar que tanto o $C D R O M$ da $A N P E D$ como as bibliotecas da USP e PUC possuem um critério próprio de organização das dissertações e teses não se podendo, portanto, generalizar os resultados obtidos, embora eles ilustrem uma amostra significativa de trabalhos publicados. No site da $A N P E D$, o CD em questão é apresentado como contendo todas as teses e dissertações publicadas no Brasil relacionadas ao tema "Educação". No entanto, observamos que houve alguns trabalhos que foram encontrados nas bibliotecas da USP e PUC (Educação) e que não constavam no $C D R O M$ da $A N P E D$. 
O CD ROM da ANPED apresenta diversos trabalhos distribuídos da seguinte forma: 7510 dissertações, 1177 teses, 1150 artigos de periódicos e 01 comunicação em evento.

A seguir, na tabela 1 temos em freqüência e porcentagem o total de dissertações e teses contidas no $C D R O M$, distribuídos em períodos de 06 anos.

TABELA 1- Freqüência e porcentagem de dissertações e teses defendidas no período de 1981 a 1998

\begin{tabular}{ccccccc}
\hline Período & \multicolumn{2}{c}{ Dissertações } & \multicolumn{3}{c}{ Teses } & \multicolumn{3}{c}{ Dissertações e Teses } \\
& frequência & $(\%)$ & frequência & $(\%)$ & frequência & $(\%)$ \\
$1981-1986$ & 1272 & 16,94 & 74 & 6.29 & 1346 & 15,49 \\
$1987-1992$ & 2337 & 31,12 & 304 & 25,83 & 2641 & 30,40 \\
$1993-1998$ & 3901 & 51,94 & 799 & 67,88 & 4700 & 54,11 \\
Total & $\mathbf{7 5 1 0}$ & $\mathbf{1 0 0}$ & $\mathbf{1 1 7 7}$ & $\mathbf{1 0 0}$ & $\mathbf{8 6 8 7}$ & $\mathbf{1 0 0}$ \\
\hline
\end{tabular}

Nesta tabela podemos observar que as defesas tanto de teses como de dissertações aumentaram ao longo desses 18 anos. O que mais chama a atenção é que no período compreendido entre 1993 e 1998, há mais de 50\% de defesas de trabalhos. Nota-se, portanto, que de fato houve um aumento significativo de trabalhos incluindo teses e dissertações no país, sobretudo considerando o último período da tabela.

A tabela 2 traz a quantidade em número e porcentagem das dissertações e teses encontradas na pesquisa realizada com o $C D$ ROM “ANPED 99: teses, dissertações $e$ 
artigos de periódicos" (1999) agrupadas em períodos de 6 anos, que contém o descritor "psicopedagogia".

TABELA 2- Frequiência e porcentagem de dissertações e teses defendidas no período de 1981 a 1998, contendo o descritor psicopedagogia dividido em períodos de 6 anos

\begin{tabular}{ccccccc}
\hline Período & \multicolumn{2}{c}{ Dissertações } & \multicolumn{2}{c}{ Teses } & \multicolumn{3}{c}{ Dissertações e Teses } \\
& frequência & $(\%)$ & frequência & $(\%)$ & frequência & $(\%)$ \\
$1981-1986$ & 18 & 12,16 & 01 & 2,38 & 19 & 10,00 \\
$1987-1992$ & 38 & 25,68 & 07 & 16,67 & 45 & 23,68 \\
$1993-1998$ & 92 & 62,16 & 34 & 80,95 & 126 & 66,32 \\
Total & $\mathbf{1 4 8}$ & $\mathbf{1 0 0}$ & $\mathbf{4 2}$ & $\mathbf{1 0 0}$ & $\mathbf{1 9 0}^{\mathbf{2 7}}$ & $\mathbf{1 0 0}$ \\
\hline
\end{tabular}

Observa-se pelos dados da tabela 2, um aumento substancial tanto de dissertações como de teses defendidas nessa área. No período de 1981-1986 para o período seguinte 1987-1992, houve um aumento de mais do dobro de dissertações e em sete vezes, o aumento de teses. No período seguinte (1993-1998), o aumento de dissertações se dá em quase três vezes em relação ao período anterior e em mais de quatro vezes o aumento de produção de teses. Como podemos observar, é no último período (1993-1998) que está 27 Das 191 dissertações e teses, uma dissertação não apresentou data, portanto não constou na tabela 2. 
concentrada a maior parte das produções $(62,16 \%$ de dissertações, $80,95 \%$ de teses, $66,32 \%$ de dissertações e teses).

Este aumento pode ter o seguinte significado: na década de 90 houve um aumento de publicações de dissertações e teses de uma maneira geral no Brasil quando comparada à década de 80, como foi observado na tabela anterior (tabela 1) podendo ter havido, conseqüentemente, um aumento geral proporcional em todos os assuntos. E o tema psicopedagogia acompanhou este aumento. No entanto, vale lembrar que a proporção dos trabalhos de psicopedagogia aumentaram em maior proporção do que os trabalhos dos outros temas. O aumento da freqüência das teses após 1993 pode estar relacionado com a continuidade dada por alguns autores em trabalhos iniciados em dissertações. No entanto, não se pode tirar muitas conclusões a respeito desse dado, pois quem muitas vezes define o tema ou palavra-chave dos trabalhos são as pessoas que fazem sua indexação e não necessariamente seus autores, dando margem a várias formas diferentes de realizar sua catalogação. Mas ainda assim a variação da porcentagem é alta e de qualquer maneira chama a atenção o termo psicopedagogia apresentar um crescimento significativo nesse último período.

Na tabela 3 podemos ver a quantidade em número e porcentagem das dissertações e teses encontradas na pesquisa realizada com o CD ROM "ANPED 99: teses, dissertações e artigos de periódicos" (1999), agrupadas por regiões do Brasil.

TABELA 3- Frequiência e porcentagem de dissertações e teses defendidas no período de 1981 a 1998 , contendo o descritor psicopedagogia, dividido pelas regiões do Brasil

$\begin{array}{llll}\text { Região } & \text { Dissertações } & \text { Teses } & \text { Dissertações e Teses }\end{array}$




\begin{tabular}{ccccccc}
\hline & frequência & $(\%)$ & frequência & $(\%)$ & frequência & $(\%)$ \\
Norte & 00 & 0 & 00 & 0 & 00 & 0 \\
Nordeste & 07 & 4,70 & 01 & 2,38 & 08 & 4,19 \\
Centro-oeste & 07 & 4,70 & 00 & 0 & 07 & 3,67 \\
Sudeste & 105 & 70,47 & 39 & 92,86 & 144 & 75,39 \\
Sul & 30 & 20,13 & 02 & 4,76 & 32 & 16,75 \\
Total & $\mathbf{1 4 9}$ & $\mathbf{1 0 0}$ & $\mathbf{4 2}$ & $\mathbf{1 0 0}$ & $\mathbf{1 9 1}$ & $\mathbf{1 0 0}$ \\
\hline
\end{tabular}

O que é possível observar nessa tabela é que a região Sudeste concentra grande parte das produções $(75,39 \%)$ relacionadas à psicopedagogia. Em seguida, vê-se a região Sul com uma porcentagem de $16,75 \%$, a região Nordeste com uma porcentagem de 4,19\% e a região Centro-oeste com 3,67\%. Não foi listada nenhuma produção na região Norte.

A tabela 4 mostra a quantidade e a porcentagem das dissertações e teses encontradas na pesquisa realizada com o $C D$ ROM "ANPED 99: teses, dissertações $e$ artigos de periódicos” (1999) agrupadas em tipos de faculdades.

TABELA 4- Freqüência e porcentagem de dissertações e teses defendidas no período de 1981 a 1998 , contendo o descritor psicopedagogia, dividido por tipo de faculdade
Tipo de
Dissertações
Teses
Dissertações e Teses

faculdades 


\begin{tabular}{ccccccc}
\hline & frequência & $(\%)$ & frequência & $(\%)$ & frequência & $(\%)$ \\
Pública & 103 & 69,13 & 25 & 59,52 & 128 & 67,02 \\
Particular & 00 & 0 & 00 & 0 & 00 & 0 \\
Confessional & 46 & 30,87 & 17 & 40,48 & 63 & 32,98 \\
Total & $\mathbf{1 4 9}$ & $\mathbf{1 0 0}$ & $\mathbf{4 2}$ & $\mathbf{1 0 0}$ & $\mathbf{1 9 1}$ & $\mathbf{1 0 0}$ \\
\hline
\end{tabular}

Na tabela 4, é possível notar que a maior parte da produção, relacionada à psicopedagogia, encontra-se nas faculdades públicas $(67,02 \%)$, seguida das faculdades confessionais $(32,98 \%)$, não constando nenhuma produção em faculdades particulares nesta listagem. É importante lembrar que o número de programas de pós-graduação das faculdades públicas é maior do que o número de programas das faculdades confessionais e que são poucas as faculdades particulares que tenham curso de Pós-graduação. E mais uma vez, não podemos nos esquecer de que embora no $C D$ ROM da $A N P E D$ conste que há todas as dissertações e teses do Brasil, já foi comentado anteriormente que essa informação não corresponde à realidade.

A tabela 5 traz os temas ou assuntos abordados nas demais dissertações e teses que não foram selecionadas para a presente pesquisa, mas que foram listadas no $C D R O M$ da ANPED contendo o descritor "psicopedagogia".

TABELA 5 - Assuntos abordados nas outras dissertações e teses que não foram selecionadas para o presente trabalho, defendidas no período de 1981 a 1998 contendo o descritor psicopedagogia 


\begin{tabular}{lcc}
\hline \multicolumn{1}{c}{ Assunto } & \multicolumn{2}{c}{ Dissertações e Teses } \\
& frequência & $\%$ \\
- afetos e suas influências na aprendizagem (psicanálise na educação); & 41 & 23,83 \\
relação psicologia, psicanálise, psicologia escolar/educação & & \\
- métodos e estratégias de ensino/aprendizagem e desenvolvimento & 22 & 12,80 \\
- influências da psicologia da educação sobre a formação do educador & 19 & 11,04 \\
- crítica social/escola & 13 & 7,56 \\
- alfabetização/leitura-escrita & 12 & 6,98 \\
- perfil e atuação do educador & 11 & 6,40 \\
- formação atuação do psicólogo em contexto escolar & 10 & 5,81 \\
- relação professor-aluno/disciplina/regras & 10 & 5,81 \\
- educação especial/psicopatologia & 06 & 3,49 \\
- pesquisa teórica em psicologia da educação ou aprendizagem & 06 & 3,49 \\
- raciocínio matemático/musical & 05 & 2,91 \\
- outros 28 & 17 & 9,88 \\
Total & $\mathbf{1 7 2}$ & $\mathbf{1 0 0}$ \\
\hline
\end{tabular}

Dos assuntos abordados envolvendo o tema psicopedagogia, mas que não foram selecionados para esta pesquisa, os mais freqüentes são: afetos e suas influências na aprendizagem (psicanálise na educação); relação psicologia, psicanálise, psicologia escolar/educação aparecendo em uma porcentagem de 23,83\%; métodos e estratégias em ensino/aprendizagem e desenvolvimento aparecendo em 12,8\% dos trabalhos não selecionados; influências da psicologia da educação sobre a formação ou atuação do educador em $11,4 \%$ dos trabalhos. Como já foi comentado anteriormente, a listagem de

\footnotetext{
${ }^{28}$ Outros assuntos ou temas encontrados com apenas uma aparição dentre as dissertações e teses colhidas: moral na criança, relação médico-paciente, concepção de homem, Psicologia Organizacional, validação de instrumentos de avaliação psicológica, discurso de alunos sobre a escola, relação entre teóricos, noções de espaço, criatividade, autoridade, o brincar. Assuntos ou temas encontrados com apenas duas aparições dentre as dissertações e teses colhidas: História da Educação/ Psicologia, aptidão/vocação e dinâmica de grupo.
} 
trabalhos que incluem o descritor "psicopedagogia" confundem-se muitas vezes com os trabalhos relacionados à Psicologia Escolar e Psicologia da Educação apontando para uma indiferenciação, falta de especificidade e identidade dessa área. Este resultado mostra que o objetivo que talvez a Psicopedagogia teria de ocupar um espaço que a Psicologia e a Pedagogia não ocuparam acaba não se cumprindo, pois o que vemos, é justamente o resultado oposto, ou seja, a Psicopedagogia sendo listada no mesmo espaço da Psicologia e Pedagogia.

Relembrando, desses trabalhos listados no $C D$ ROM da $A N P E D$, apenas uma parcela deles foi selecionada para esta pesquisa. Esta amostra selecionada inclui todas as dissertações e teses que apresentam o termo "psicopedagogia" evidenciado no título e/ou resumo do trabalho. As próximas tabelas (6 a 9) mostram dados dessa amostra selecionada.

Na tabela 6, apresentamos a quantidade em número e proporção das dissertações e teses selecionadas para a presente pesquisa agrupadas em períodos de 6 anos.

TABELA 6- Freqüência e proporção de dissertações e teses defendidas no período de 1981 a 1998, contendo o descritor psicopedagogia dividido em períodos de 6 anos, selecionadas para esta pesquisa

\begin{tabular}{ccccccc}
\hline Período & \multicolumn{2}{c}{ Dissertações } & \multicolumn{2}{c}{ Teses } & \multicolumn{2}{c}{ Dissertações e Teses } \\
& frequência & proporção & frequência & proporção & frequência & proporção \\
$1981-1986$ & 02 & 0,1 & 00 & 0 & 02 & 0,1 \\
$1987-1992$ & 03 & 0,2 & 01 & 0,3 & 04 & 0,2 \\
$1993-1998$ & 11 & 0,7 & 02 & 0,7 & 13 & 0,7 \\
Total & $\mathbf{1 6}$ & $\mathbf{0 1}$ & $\mathbf{0 3}$ & $\mathbf{0 1}$ & $\mathbf{1 9}$ & $\mathbf{0 1}$ \\
\hline
\end{tabular}


Podemos notar que quando o termo "psicopedagogia" é colocado de uma maneira mais específica, ou seja, de acordo com os critérios estabelecidos para selecionar dissertações e teses para esta pesquisa (aparecer a palavra psicopedagogia no título e/ou resumo da obra), o aumento progressivo de publicações praticamente não se altera quando comparado com a publicação de trabalhos de psicopedagogia sem o uso do critério utilizado nessa pesquisa. Quando comparamos esta tabela com a tabela 2, observamos que os trabalhos produzidos entre 1981 a 1986 tiveram uma aparição em 10\% na amostra colhida no $C D R O M$, e nesta amostra selecionada para a pesquisa temos a proporção de 0,1. No período de $1987-1992$, temos na tabela 2 um percentual de $23,68 \%$ de trabalhos apresentados e nesta tabela temos a proporção de 0,2. E finalmente no período de 1993 1998, temos no primeiro caso um percentual de $66,32 \%$ e, no segundo caso, uma proporção de 0,7 .

Em relação às teses selecionadas o mesmo não acontece, havendo uma maior especificação do termo "psicopedagogia" apenas no período que compreende os anos 1987 a 1992 e nos demais havendo uma diminuição, ou seja, na tabela 2 temos $2,38 \%$ de publicações de teses no intervalo de 1981-1986 e na tabela 6 não há teses selecionadas; para o período $1987-1992$, temos $16,67 \%$ de teses publicadas sobre psicopedagogia e 0,3 selecionadas para esta pesquisa; para o período 1993-1998 a tabela 2 mostra um percentual de $80,95 \%$ e na tabela 6 , uma proporção de 0,7 .

Ao analisarmos a publicação de dissertações isoladamente temos comparativamente: $12,16 \%$ na tabela 2 e 0,1 na tabela 4 para o período $1981-1986 ; 25,68 \%$ 
na tabela 2 e 0,2 para o período de $1987-1992 ; 62,16 \%$ na tabela 2 e 0,7 na tabela 4 para o último período selecionado.

A tabela 7 traz a quantidade em número e proporção das dissertações e teses selecionadas para a presente pesquisa agrupadas por regiões do Brasil.

TABELA 7- freqüência e proporção de dissertações e teses defendidas no período de 1981 a 1998, contendo o descritor psicopedagogia dividido pelas regiões do Brasil, selecionadas para esta pesquisa

\begin{tabular}{ccccccc}
\hline Região & \multicolumn{2}{c}{ Dissertações } & \multicolumn{2}{c}{ Teses } & \multicolumn{2}{c}{ Dissertações e Teses } \\
& frequência & proporção & frequência & proporção & frequência & proporção \\
Norte & 00 & 0 & 00 & 0 & 00 & 0 \\
Nordeste & 00 & 0 & 00 & 0 & 00 & 0 \\
Centro-oeste & 00 & 0 & 00 & 0 & 00 & 0 \\
Sudeste & 10 & 0,6 & 02 & 0,7 & 12 & 0,6 \\
Sul & 06 & 0,4 & 01 & 0,3 & 07 & 0,4 \\
Total & $\mathbf{1 6}$ & $\mathbf{0 1}$ & $\mathbf{0 3}$ & $\mathbf{0 1}$ & $\mathbf{1 9}$ & $\mathbf{0 1}$ \\
\hline
\end{tabular}

$\mathrm{Na}$ amostra selecionada, apenas as regiões Sul e Sudeste apresentam dissertações e teses com o termo "psicopedagogia" especificado no título e resumo das mesmas. Portanto, esta amostra não possui uma correspondência direta com os dados percentuais colhidos diretamente no $C D R O M$ da ANPED. Comparando a tabela 3 com esta, observamos que na primeira, as regiões Nordeste e Centro-Oeste apresentavam uma porcentagem de publicações de trabalhos em 4,19\% e 3,67\% respectivamente. A região 
Sudeste apresentava 75,39\% de trabalhos publicados e aqui selecionados temos 0,6 da amostra e a região Sul apresentou $16,75 \%$ de trabalhos no primeiro caso e nesta amostra, 0,4 .

A tabela 8 mostra a quantidade em número e proporções das dissertações e teses selecionadas para a presente pesquisa agrupadas por tipo de faculdade.

TABELA 8 - freqüência e proporção de dissertações e teses defendidas no período de 1981 a 1998, contendo o descritor psicopedagogia dividido por tipo de faculdade, selecionadas para esta pesquisa

Tipo de $\quad$ Dissertações $\quad$ Teses $\quad$ Dissertações e Teses

faculdade

frequência proporção frequência proporção frequência proporção

Pública

06

0,4

03

01

09

0,4

Particular

00

00

00

00

00

00

Confessional

10

0,6

00

00

10

0,6

Total

16

01

03

01

19

01

Nessa amostra selecionada podemos observar que a proporção de trabalhos publicados aparecem em 0,4 em faculdades públicas e 0,6 em faculdades confessionais. Estes dados se apresentam de uma maneira diferente dos dados coletados no $C D R O M$, ou seja, nele a maior porcentagem de trabalhos vêm das faculdades públicas $(67,02 \%)$ seguidos dos trabalhos das faculdades confessionais (32,98\%). Assim, ao que parece, as faculdades confessionais se utilizam do tema "psicopedagogia" de uma maneira mais específica do que as demais faculdades. 
Na tabela 9 encontramos a quantidade em número e proporção das dissertações e teses selecionadas para a presente pesquisa sendo especificadas pela faculdade ou universidade em que foram realizadas.

TABELA $9^{\mathbf{2 9}}$ - Freqüência e proporção de dissertações e teses defendidas no período de 1981 a 1998 , contendo o descritor psicopedagogia por nome da faculdade, selecionadas para esta pesquisa

\begin{tabular}{|c|c|c|c|c|c|c|}
\hline \multirow[t]{2}{*}{ Local de defesa } & \multicolumn{2}{|c|}{ Dissertações } & \multicolumn{2}{|c|}{ Teses } & \multicolumn{2}{|c|}{ Dissertações e Teses } \\
\hline & frequência & proporção & frequência & proporção & frequência & proporção \\
\hline PUC - R. S. & 05 & 0,3 & 00 & 00 & 05 & 0,3 \\
\hline USP - capital & 02 & 0,1 & 01 & 0,3 & 03 & 0,2 \\
\hline Unicamp & 01 & 0,1 & 01 & 0,3 & 02 & 0,1 \\
\hline PUC - S.P. & 02 & 0,1 & 00 & 00 & 02 & 0,1 \\
\hline PUC - R. J. & 02 & 0,1 & 00 & 00 & 02 & 0,1 \\
\hline Unesp Marilia & 01 & 0,1 & 00 & 00 & 01 & 0,1 \\
\hline Um. Fed. & 01 & 0,1 & 00 & 00 & 01 & 0,1 \\
\hline \multicolumn{7}{|l|}{ Fluminense } \\
\hline Un. Fed. Paraná & 01 & 0,06 & 00 & 00 & 01 & 0,05 \\
\hline Un. Metodista de & 01 & 0,06 & 00 & 00 & 01 & 0,05 \\
\hline \multicolumn{7}{|l|}{ Piracicaba } \\
\hline Un. Fed. R.S. & 00 & 00 & 01 & 0,3 & 01 & 0,05 \\
\hline Total & 16 & 01 & 03 & 01 & 19 & 01 \\
\hline
\end{tabular}

${ }^{29} \mathrm{Em}$ algumas tabelas, a soma da proporção pode ser menor ou maior que 1 devido às aproximações necessárias para se obter uma casa decimal. 
Podemos observar que a maior parte dos trabalhos vêm da PUC-RS $(0,3)$ seguidos da USP $(0,2)$. As demais faculdades aparecem com uma proporção de 0,1 . Em relação às dissertações, a PUC-RS é a que aparece com uma maior proporção $(0,3)$ de publicações selecionadas para esta pesquisa.

A seguir, as tabelas de 10 a 13 são relativas à pesquisa realizada na USP-SP e PUC-SP nos cursos de pós-graduação em Psicologia e Educação.

A tabela 10 está dividida em 2 partes (a e b) mostrando a quantidade em número e proporção das dissertações e teses encontradas na pesquisa realizada nos programas de pós-graduação em Psicologia e Educação das universidades USP-capital e PUC-SP agrupadas por períodos de 5 anos.

Na tabela 10a temos as dissertações e teses do programa de Psicologia da USP e PUC-SP em freqüência e proporção.

TABELA 10a - Freqüência e proporção de dissertações e teses do programa de Pós-graduação da Psicologia PUC-SP e USP-capital, defendidas no período de 1981 a 2001 contendo o descritor psicopedagogia como assunto ou palavra-chave dividido em períodos de 5 anos

\begin{tabular}{ccccccc}
\hline Período & \multicolumn{2}{c}{ Dissertações } & \multicolumn{2}{c}{ Teses } & \multicolumn{2}{c}{ Dissertações e Teses } \\
& $\mathrm{f}$ & $\mathrm{p}$ & $\mathrm{f}$ & $\mathrm{p}$ & $\mathrm{f}$ & $\mathrm{p}$ \\
$81-85$ & 00 & 00 & 00 & 00 & 00 & 00 \\
$86-90$ & 01 & 0,2 & 01 & 0,2 & 02 & 0,2 \\
\hline
\end{tabular}




\begin{tabular}{ccccccc}
\hline $91-95$ & 01 & 0,2 & 01 & 0,2 & 02 & 0,2 \\
$96-00^{30}$ & 02 & 0,5 & 04 & 0,6 & 06 & 0,6 \\
Total & $\mathbf{0 4}$ & $\mathbf{0 1}$ & $\mathbf{0 6}$ & $\mathbf{0 1}$ & $\mathbf{1 0}$ & $\mathbf{0 1}$ \\
\hline
\end{tabular}

Na produção encontrada nos programas de Psicologia, observa-se um aumento da produção relativa a psicopedagogia. De 1986 a 1995, a produção se mantém a mesma. A partir da segunda metade da década de 90 a produção tem um aumento substancial, abrangendo 0,6 da amostra. O mesmo acontece quando analisamos a produção de dissertações e teses isoladamente.

Na tabela 10b temos as dissertações e teses do programa de Educação da USP e PUC-SP em freqüência e proporção.

TABELA 10b- Freqüência e proporção de dissertações e teses do programa de Pós-graduação da Educação PUC-SP e USP-capital, defendidas no período de 1981 a 2001 contendo o descritor psicopedagogia como assunto ou palavra-chave dividido em períodos de 5 anos

\begin{tabular}{ccccccc}
\hline Período & \multicolumn{2}{c}{ Dissertações } & \multicolumn{2}{c}{ Teses } & \multicolumn{2}{c}{ Dissertações e Teses } \\
& $\mathrm{f}$ & $\mathrm{p}$ & $\mathrm{f}$ & $\mathrm{p}$ & $\mathrm{f}$ & $\mathrm{p}$ \\
$81-85$ & 00 & 00 & 01 & 0,1 & 01 & 0,1 \\
$86-90$ & 00 & 00 & 01 & 0,1 & 01 & 0,1 \\
$91-95$ & 11 & 0,4 & 02 & 0,2 & 13 & 0,2 \\
$96-01$ & 19 & 0,6 & 05 & 0,6 & 24 & 0,6 \\
Total $^{\mathbf{3 1}}$ & $\mathbf{3 0}$ & $\mathbf{0 1}$ & $\mathbf{0 9}$ & $\mathbf{0 1}$ & $\mathbf{3 9}$ & $\mathbf{0 1}$ \\
\hline
\end{tabular}

\footnotetext{
${ }^{30}$ Em 1999 foi defendida uma tese de livre docência no Instituto de Psicologia da USP que não consta nesta tabela e que também não foi selecionada para esta pesquisa, mas foi contabilizada no total dos trabalhos coletados no programa de pós-graduação de Psicologia.
} 
É possível observar o aumento dos trabalhos apresentados em relação à psicopedagogia pelos programas de pós-graduação em Educação. Até o fim dos anos 80, não houve uma produção significativa em relação a este assunto, mas a partir dos anos 90 há uma elevação na quantidade de trabalhos apresentados e quando se observa a segunda metade da década, é possível notar o aumento ainda maior, resultando em 0,6 da amostra coletada. O mesmo ocorre ao se analisar a produção isolada de teses. No entanto, a produção de dissertações teve um aumento a partir dos anos 90.

Fica nítido como os trabalhos apresentados sobre o tema psicopedagogia são mais frequientes no programa de pós-graduação da Educação do que no programa da Psicologia: enquanto a Educação produziu 39 trabalhos incluindo 30 dissertações e 09 teses sobre o assunto, a Psicologia produziu 10 trabalhos, incluindo quatro dissertações e seis teses neste mesmo período. Pelo que apontam os resultados, a diferença está principalmente na produção de dissertações (de 30 para 4), pois na publicação de teses a diferença é menor (9 para 6).

Da mesma maneira que foi feita uma seleção das dissertações e teses compondo uma amostra do $C D R O M$ da $A N P E D$, o mesmo foi feito também com a pesquisa realizada nos programas de pós-graduação de Educação e Psicologia da USP-capital e PUC-SP, ou seja, foram selecionadas dissertações e teses utilizando os mesmos critérios usados anteriormente.

\footnotetext{
${ }^{31}$ Deste total de trabalhos coletados, 2 dissertações e 1 tese da Faculdade de Educação da USP também aparece no cd rom da ANPED, o mesmo se repetindo com 1 dissertação e 3 teses do programa de pós-graduação da PUC em Educação.
} 
Na tabela 11 observamos temas ou assuntos abordados nas demais dissertações e teses que não foram selecionadas para o presente trabalho, mas que foram listadas na pesquisa realizada nas faculdades de Educação da PUC-SP e USP-SP contendo o descritor "psicopedagogia" como palavra-chave ou assunto.

TABELA 11- Assuntos abordados nas outras dissertações e teses que não foram selecionadas para o presente trabalho defendidas no período de 1981 a 2001 contendo o descritor psicopedagogia como palavra-chave ou assunto no programa de pós-graduação da PUC-SP e USP-capital de Educação

\begin{tabular}{|c|c|c|}
\hline \multirow[t]{2}{*}{ Assunto } & \multicolumn{2}{|c|}{ Dissertações e Teses } \\
\hline & frequência & proporção \\
\hline - influência da psicologia na formação do educador & 06 & 0,2 \\
\hline - projetos educacionais/estratégias de ensino e desenvolvimento & 06 & 0,2 \\
\hline - atuação do educador & 04 & 0,1 \\
\hline - educação de jovens e adultos & 03 & 0,1 \\
\hline - educação especial & 03 & 0,1 \\
\hline - outros ${ }^{32}$ & 11 & 0,3 \\
\hline Total & 33 & 01 \\
\hline
\end{tabular}

Das dissertações e teses não selecionadas para esta pesquisa publicadas nas faculdades de Educação da USP e PUC temos como temas: influência da psicologia na formação do educador/ projetos educacionais/estratégias de ensino e desenvolvimento aparecendo numa proporção de 0,2 desses trabalhos; atuação do educador aparecendo numa proporção de 0,1 ; educação de jovens e adultos/ educação especial constando em 0,1 dos trabalhos e demais temas aparecem em uma proporção de 0,3 . Novamente nota-se a

32 Outros assuntos referidos com 2 ou 1 aparição: alfabetização, aprendizagem musical, aprendizagem matemática, psicologia escolar, conceituação de infância, atenção. 
tendência dos temas abordados pela psicopedagogia serem próximos ou muito semelhantes aos temas relacionados a Psicologia Escolar e Psicologia da Educação.

A tabela 12 mostra os temas ou assuntos abordados nas demais dissertações e teses que não foram selecionadas para o presente trabalho, mas que foram listadas na pesquisa realizada nos programas de pós-graduação de Psicologia da PUC-SP e USP-SP contendo o descritor "psicopedagogia" como palavra-chave ou assunto.

TABELA 12 - Assuntos abordados nas outras dissertações e teses que não foram selecionadas para o presente trabalho defendidas no período de 1981 a 2001 contendo o descritor psicopedagogia como palavra-chave ou assunto no programa de pós-graduação da PUC-SP e USP-capital de Psicologia

\begin{tabular}{lcc}
\hline \multicolumn{1}{c}{ Assunto } & \multicolumn{2}{c}{ Dissertações e Teses } \\
& Freqüência & proporção \\
- crítica à psicologia clínica & 02 & 0,5 \\
- aplicação prática da fundamentação piagetiana & 01 & 0,3 \\
- políticas educacionais & 01 & 0,3 \\
Total & $\mathbf{0 4}$ & $\mathbf{0 1}$ \\
\hline
\end{tabular}

Das dissertações e teses não selecionadas para esta pesquisa publicadas nas faculdades de Psicologia da USP e PUC temos como temas: crítica à psicologia clínica em metade da amostra, seguidos de aplicação prática da fundamentação piagetiana e políticas educacionais em 0,2 da amostra cada um desses temas.

O que é possível observar é que os temas quando tratados nas faculdades de Educação se diversificam mais do que os das faculdades de Psicologia. 
A tabela 13 também foi dividida em a e b para facilitar a visualização da quantidade em dados brutos e proporção das dissertações e teses defendidas no período de 1981 a 2001 contendo o descritor psicopedagogia como palavra-chave ou assunto no programa de pós-graduação em Psicologia e Educação da USP-capital e PUC-SP dividido em períodos de 5 anos, selecionadas para esta pesquisa.

Na tabela 13a temos as dissertações e teses dos programas de Psicologia da USP e PUC-SP em freqüência e proporção selecionadas para esta pesquisa.

TABELA 13a - Freqüência e proporção de dissertações e teses do programa de Pós-graduação da Psicologia PUC-SP e USP-capital, defendidas no período de 1981 a 2001, contendo o descritor psicopedagogia como assunto ou palavra-chave dividido em períodos de 5 anos, selecionadas para esta pesquisa

\begin{tabular}{ccccccc}
\hline Período & \multicolumn{2}{c}{ Dissertações } & \multicolumn{2}{c}{ Teses } & \multicolumn{2}{c}{ Dissertações e Teses } \\
& $\mathrm{f}$ & $\mathrm{p}$ & $\mathrm{f}$ & $\mathrm{p}$ & $\mathrm{F}$ & $\mathrm{p}$ \\
$81-85$ & 00 & 00 & 00 & 00 & 00 & 00 \\
$86-90$ & 01 & 0,3 & 01 & 0,3 & 02 & 0,3 \\
$91-95$ & 01 & 0,3 & 01 & 0,3 & 02 & 0,3 \\
$96-00$ & 01 & 0,3 & 01 & 0,3 & 02 & 0,3 \\
Total & $\mathbf{0 3}$ & $\mathbf{0 1}$ & $\mathbf{0 3}$ & $\mathbf{0 1}$ & $\mathbf{0 6}$ & $\mathbf{0 , 1}$ \\
\hline
\end{tabular}

Dos trabalhos selecionados para a pesquisa, temos no programa de Psicologia a mesma proporção de trabalhos selecionados em todos os períodos com exceção do primeiro (1981-1985) que não foi selecionado nenhum trabalho. No universo das 
produções há também uma estabilidade nas produções com exceção do período de 1996 a 2000 que compreende 0,6 dos trabalhos (vide tabela 10a). Pelo que parece, talvez o termo psicopedagogia passou a ser mais utilizado abrangendo outras áreas que não só esta própria.

Na tabela 13b temos as dissertações e teses do programa de Educação da USP e PUC-SP em frequiência e proporção selecionadas para esta pesquisa.

TABELA 13b - Freqüência e proporção de dissertações e teses do programa de Pós-graduação da Educação PUC-SP e USP-capital, defendidas no período de 1981 a 2001 contendo o descritor psicopedagogia como assunto ou palavra-chave dividido em períodos de 5 anos, selecionadas para esta pesquisa

\begin{tabular}{ccccccc}
\hline Período & \multicolumn{2}{c}{ Dissertações } & \multicolumn{2}{c}{ Teses } & \multicolumn{2}{c}{ Dissertações e Teses } \\
& $\mathrm{f}$ & $\mathrm{p}$ & $\mathrm{f}$ & $\mathrm{p}$ & $\mathrm{F}$ & $\mathrm{p}$ \\
$81-85$ & 00 & 00 & 00 & 00 & 00 & 00 \\
$86-90$ & 00 & 00 & 00 & 00 & 00 & 00 \\
$91-95$ & $01^{\bullet}$ & 0,2 & 00 & 00 & 01 & 0,2 \\
$96-00$ & $04^{\star}$ & 0,8 & $01^{\mathbf{3 3}}$ & 1,0 & 05 & 0,8 \\
Total & $\mathbf{0 5}$ & $\mathbf{0 1}$ & $\mathbf{0 1}$ & $\mathbf{0 1}$ & $\mathbf{0 6}$ & $\mathbf{0 1}$ \\
\hline
\end{tabular}

No programa de Educação, considerando os quatro períodos, podemos observar um aumento progressivo dos trabalhos selecionados a partir de $1991(0,2$ e 0,8 respectivamente). Houve um aumento progressivo também na produção do universo pesquisado, a partir da década de 90 também.

\footnotetext{
-

${ }^{33}$ Em cada um desses períodos, há teses (uma em cada um deles, 3 no total) que aparecem na coleta de dados do $C D R O M$ da $A N P E D$ e que portanto, também foram selecionadas para esta pesquisa.
} 
O mesmo ocorre com as dissertações e com as teses, pois há apenas uma tese no último período (1996-2000). 
- Capítulo 5 -

\section{Análise das dissertações e teses}




\section{Análise das dissertações e teses}

A seguir, nas tabelas de 14 a 20, serão apresentados os dados colhidos na leitura das dissertações e teses selecionadas para este trabalho.

O total dos trabalhos lidos é de 24 , sendo 15 trabalhos da ANPED, seis dos programas de Pós-graduação de faculdades de Psicologia e três dos programas de Pósgraduação de faculdades de Educação. As dissertações e teses que se repetem na ANPED e programa de Pós-graduação em faculdades de Educação foram contabilizados apenas uma vez na tabela referente aos trabalhos da $A N P E D$. Aliás, esta divisão de quantidade de trabalhos entre ANPED e programas de Pós-graduação em faculdades de Psicologia e Educação já foram contabilizados levando em consideração tal critério de repetição.

Nas tabelas podem aparecer números superiores aos citados acima, uma vez que o item da tabela denominado "total" é relativo ao item analisado e não ao número de obras analisadas. Por exemplo, na tabela 14a, na qual estão caracterizadas as concepções de Psicopedagogia existentes nas 15 dissertações e teses da $A N P E D$, aconteceu de em um mesmo trabalho ter aparecido mais de uma concepção, que foi assim, computada nessa tabela, ultrapassando, portanto no total, o número de 15 e totalizando 28 . O número 28 corresponde assim, ao total de concepções encontradas nas 15 dissertações e teses.

As respectivas tabelas tratam dos seguintes assuntos analisados nas dissertações e teses: concepções de Psicopedagogia apresentadas em cada uma delas; objetivos apresentados; tipo de pesquisa, ou seja, se teórica ou empírica; referenciais teóricos adotados e conclusões obtidas. Finalmente, as duas últimas tabelas tratam dos temas 
"adaptação" e "emancipação", sendo que na primeira delas são analisadas as dissertações e teses que tiveram a preocupação em citar ou não os dois termos e na segunda tabela são verificados se os trabalhos tomaram uma direção voltada para uma educação emancipatória.

A seqüência das tabelas foi organizada da seguinte maneira: para cada assunto elas são apresentadas em três subdivisões sendo a primeira delas dedicada aos trabalhos da ANPED; a segunda delas aos trabalhos dos programas de Pós-graduação em faculdades de Psicologia, seguido da terceira tabela com os trabalhos dos programas de Pós-graduação das faculdades de Educação.

$\mathrm{Na}$ tabela 14a temos a freqüência e proporção das concepções entendidas para Psicopedagogia nas dissertações e teses analisadas da ANPED.

TABELA 14a - Frequiência e proporção de concepções entendidas para Psicopedagogia nas dissertações e teses da $A N P E D$

\section{Concepções}

Prática clínica, estratégia ou área que estuda processos e/ou problemas e/ou modalidades de aprendizagem

Termo que une Psicologia e Pedagogia ou ciência multi e interdisciplinar

Área da aprendizagem com função curativa e/ou preventiva

Ciência autônoma

Não adota concepção

Área que cria novas propostas metodológicas relacionadas à educação

Inter-relações entre elementos cognitivos, afetivos e sociais da aprendizagem

Clínica ortopédica que alimenta o discurso hegemônico da Pedagogia

Total

\section{frequência proporção}

11

0,4

05

0,2

05

0,2

02

0,1

02

0,1

01

0,0

01

0,0

01

0,0 
Segundo os dados da tabela 14a, observamos que dentre as concepções de Psicopedagogia, as mais freqüentes foram aquelas que apareceram em mais da metade das dissertações e teses e em 0,4 das categorias de resposta e que disseram ser a Psicopedagogia uma prática clínica, estratégia ou área que estuda processos elou problemas de aprendizagem elou modalidades de aprendizagem; em seguida temos com 0,2 das aparições, ou seja, em cinco trabalhos a Psicopedagogia como termo que une Psicologia e Pedagogia ou ciência multi e interdisciplinar e área da aprendizagem com função curativa elou preventiva. Ainda tivemos duas aparições de trabalhos que entendem a Psicopedagogia como uma ciência autônoma. E com apenas uma aparição temos a Psicopedagogia entendida como área que cria novas propostas metodológicas relacionadas à educação; inter-relações entre elementos cognitivos, afetivos e sociais da aprendizagem e clínica ortopédica que alimenta o discurso hegemônico da Pedagogia. É importante notar que apenas neste último trabalho, houve uma preocupação em apresentar uma concepção crítica da Psicopedagogia. Há dois trabalhos que não apresentam qual concepção adotam o que causa uma estranheza, pois é de extrema importância mostrar de que lugar estamos falando sobre um determinado assunto. Depois vemos que eles não adotam concepções pois justamente esta é a preocupação deles: analisar as concepções da Psicopedagogia embora isso não exclua o fato deles adotarem a sua própria concepção.

De uma maneira geral, a Psicopedagogia é considerada uma estratégia, área ou prática destinada a entender, prevenir e ajudar pessoas com problemas de aprendizagem ou ainda entender, prevenir e ajudar nos problemas de aprendizagem. $\mathrm{O}$ foco da Psicopedagogia é duplo: alguns trabalhos enfocam mais o ser humano que deve ser entendido e "trabalhado" para resolver seus problemas de aprendizagem ou evitar um 
futuro problema relacionado com aprendizagem; outros trabalhos enfocam, em sua definição de Psicopedagogia, o processo de aprendizagem em si considerando suas dificuldades e problemas. O que chama a atenção é que embora as definições sejam diversificadas, os autores utilizam ambos tipos de concepções em seus trabalhos.

Além disso, a aprendizagem é vista como um problema a ser solucionado ou prevenido, lembrando muito uma visão médica, que procura prevenir ou solucionar doenças ou síndromes. Como já vimos no Capítulo 2, a Psicopedagogia sofreu e sofre influência da Medicina e isso se reflete nos trabalhos. Isso é ainda mais reforçado na definição que diz que a Psicopedagogia é uma prática clínica que cuida dos problemas de aprendizagem. Neste caso, a Psicopedagogia pode ser entendida como uma prática de consultório que enxerga o aluno como um paciente a ser tratado, o problema é pontual, localiza-se no aluno ou instituições como sua família ou sua escola. Assim, se ele for encaminhado para um outro tipo de escola o problema pode resolver-se automaticamente, revelando que o problema de aprendizagem é uma simples questão de adaptação a certo tipo de ambiente educacional. O problema portanto é visto pontualmente.

Outra tentativa da Psicopedagogia é unir Pedagogia e Psicologia e tentar "cobrir" faltas que ambas as áreas possuem em relação a questões relacionadas com a aprendizagem. Essa alternativa também foi uma das que mais aparece. Em algumas dissertações foi possível observar uma preocupação da Psicopedagogia em suprir faltas dizendo que tal área de conhecimento engloba Sociologia, Medicina, Linguística etc. Ou seja segundo as concepções de Psicopedagogia que apareceram nessas dissertações e teses esta área de conhecimento ou estratégia ou prática clínica vem para resolver problemas que outras áreas do conhecimento não conseguiram sozinhas e, para isso, uniu diversas áreas 
de conhecimento para conseguir resolver o que outras áreas não conseguiram em relação às questões relacionadas à aprendizagem. Fica subentendido que o problema da aprendizagem pode ser resolvido pela quantidade, pela soma de áreas do conhecimento, seja ela a Medicina, a Psicologia, a Lingüística etc. Como até então ainda não foi possível resolver os problemas de aprendizagem, entende-se que apenas unindo diversas ciências este fim será alcançado. Assim, optam pela quantidade de técnicas e conhecimento de maneira a tentar suprir as falhas na Educação ocorridas até então.

Nessas concepções não fica bem especificado que tipo de aprendizagem que a Psicopedagogia está preocupada, mas pelo contexto dos trabalhos é possível perceber que o foco está principalmente nos problemas de aprendizagem escolares, no conteúdo que as escolas passam aos alunos e esses não conseguem aprender. Ainda que citem autores preocupados com questões relacionadas ao desenvolvimento do pensamento, ainda assim preferem dar ênfase a uma educação conteudística, mais preocupada em informar do que formar, Educação que na era da informação é a mais esperada, é aquele tipo de educação, pseudoformação.

Cabe ainda a Psicopedagogia realizar propostas metodológicas que propiciem aos alunos aprendizagem dos conteúdos escolares. A Psicopedagogia ao analisar ou fazer propostas para as questões relacionadas à aprendizagem procura levar em consideração os aspectos orgânicos, afetivos e socioculturais. No entanto, embora a maior parte das dissertações e teses citem estes aspectos, no corpo do trabalho, os aspectos sociais na maior parte das vezes não são levados em consideração, havendo uma maior ênfase nos orgânicos e principalmente nos emocionais. Desses trabalhos, em apenas um ("A invenção da 
adolescência no discurso psicopedagógico") o aspecto social foi considerado, discutido e contemplado durante a análise.

É importante lembrar que em uma das dissertações, "Psicopedagogia: um perfil profissional em conflito", a autora chama a atenção para a insuficiência de definições para a Psicopedagogia. No entanto foi possível observar várias definições ao longo dos trabalhos e por parte de autores da área, portanto não sendo verdadeira essa afirmação. $\mathrm{O}$ que parece ocorrer é uma falta de unidade entre elas além de uma maior diferenciação dessas definições quando relacionadas com a Pedagogia, Psicologia, Psicologia da Educação, Psicologia Escolar e Psicologia da Aprendizagem, o que parece ser difícil levando em consideração que a Psicopedagogia se proponha a unir tantas áreas de conhecimento simultaneamente. Mas aponta, logo em seguida, que há a definição da Associação Brasileira de Psicopedagogia (Abpp) “A psicopedagogia é a área que estuda e lida com os processos de aprendizagem e suas dificuldades (1990)".

A autora do trabalho "A atuação do profissional em Psicopedagogia e a formação do psicopedagogo em São Paulo no período de 1980 a 1990" discute a falta de identidade da Psicopedagogia enquanto área que necessita de um único profissional: o psicopedagogo. Seus conteúdos são do interesse de diversos profissionais, parecendo a defesa do profissional psicopedagogo mais coorporativa do que uma necessidade real. A autora também considera a Psicopedagogia uma área muito ampla tornando-se "panacéia dos males da aprendizagem e do ensino, esvaziando seu sentido”. Entende que estamos diante de as "psicopedagogias", isoladas umas das outras, o que não confere identidade para a área. Sendo assim, sua concepção fica muitas vezes intuída. 
De uma maneira geral, embora os autores das dissertações e teses apresentem definições para a Psicopedagogia, parece ainda não haver um consenso sobre a identidade da mesma. A maior parte dos autores alega que esta falta de identidade se deve pelo fato dessa área de conhecimento ser relativamente nova. $\mathrm{Na}$ verdade, esta falta de identidade estaria relacionada ao não cumprimento daquilo que ela se propõe, ou seja, cobrir as lacunas deixadas por duas áreas do conhecimento (Psicologia e Pedagogia) transcendendo seus limites. Ela acaba não realizando o que se propõe pelo menos até então.

\footnotetext{
"A Psicopedagogia se ocupa da aprendizagem humana, que adveio de uma demanda - o problema de aprendizagem, colocado num território pouco explorado, situado além dos limites da Psicologia e da própria Pedagogia... constituindo-se assim, numa prática. Como se preocupa com o problema de aprendizagem, deve ocupar-se inicialmente do processo de aprendizagem" (BOSSA, 2000:21).
}

Ou ainda, podemos ver uma ênfase dada à concepção de Psicopedagogia como "ciência da prática". Já que não encontra uma singularidade, a prática muitas vezes acaba sendo sua marca registrada, revelando como essa área do conhecimento está em "sintonia" com a sociedade administrada em que vivemos, onde a técnica, a eficiência, a prática (saber fazer) possuem uma importância extrema, deixando em segundo plano a reflexão por exemplo, a conscientização e todos outros aspectos que permitam uma possibilidade de suplantar este tipo de sociedade, caminhando no sentido de uma educação emancipatória. No trabalho "Psicopedagogia Institucional: a trajetória de seus atores-autores" essa concepção fica bem clara uma vez que é ressaltada no mesmo trabalho. Por exemplo, “...criou novas alternativas de ações, permitindo uma intervenção além da pedagogia, contribuindo com a ciência da prática. (NOFFS, 1996:10). É a defesa do "saber aplicar" e o "saber fazer" como uma inovação, como a solução para todos os problemas relacionados ao assunto. 
Na tabela 14b temos a freqüência e proporção das concepções entendidas para Psicopedagogia nas dissertações e teses analisadas dos programas de Pós-graduação das faculdades de Psicologia.

TABELA 14b - Freqüência e proporção de concepções entendidas para Psicopedagogia nas dissertações e teses dos programas de pós-graduação das faculdades de Psicologia

\section{Concepções}

Prática clínica, estratégia ou área que estuda processos e/ou problemas e/ou modalidades de aprendizagem

Não diz

Termo que une Psicologia e Pedagogia ou ciência multi e interdisciplinar

\section{frequência proporção}

$04 \quad 0,6$

02

01

0,3

0,1

Total

07

01

Igualmente, nos trabalhos defendidos nos programas de Pós-graduação das faculdades de Psicologia a maior parte dos trabalhos, quatro de seis $(0,6$ das possibilidades de resposta) entendem a Psicopedagogia como prática clínica, estratégia ou área que estuda processos elou problemas de aprendizagem.

Um fato que chama a atenção é que nos trabalhos defendidos nos programas de Pós-graduação das faculdades de Psicologia a maior parte dos trabalhos, quatro de seis, não explicitam sua concepção de Psicopedagogia. No entanto só apontamos dois deles como não dizendo a concepção que adotam porque em dois deles não são explicitadas e não é possível tentar deduzir ao longo dos mesmos trabalhos. Nos outros dois é possível tentar deduzir o que entendem por Psicopedagogia: de maneira adjetivada como aplicação da Psicologia à Pedagogia ou a intersecção de ambas e sua aplicação na clínica ou escola. Essa é uma postura muito comum, segundo Bossa (2000), utilizada no início da década de 80 aqui no Brasil. No entanto, essa tendência perdurou ao longo dessa década e na seguinte também, pelo menos no que consta nas faculdades de Psicologia da USP e PUC. Parece 
que por parte desses autores não há uma preocupação imediata em estudar a Psicopedagogia como uma área autônoma ou talvez não tenham consciência de sua existência ou pelo fato de não entenderem como sendo uma área independente das demais.

Na tabela 14c temos a freqüência e proporção das concepções entendidas para Psicopedagogia nas dissertações e teses analisadas dos programas de Pós-graduação das faculdades de Educação.

TABELA 14c - Freqüência e proporção de concepções entendidas para Psicopedagogia nas dissertações e teses dos programas de pós-graduação das faculdades de Educação

\section{Concepções}

Prática clínica, estratégia ou área que estuda processos e/ou problemas e/ou modalidades de aprendizagem

inter-relações entre elementos cognitivos, afetivos e sociais da aprendizagem

Não diz

Total frequência proporção

01

0,3

01

0,3

01

0,3

03

Na tabela 14c observamos também repetições de concepções encontradas nos trabalhos defendidos na ANPED e nas faculdades de Psicologia (PUC-SP e USP-SP): Psicopedagogia como prática e que estuda problemas de aprendizagem pertencentes ao sujeito que não aprende e área que estuda a aprendizagem que é realizada pela inter-relação de elementos cognitivos, afetivos e sociais. Aqui mais uma vez chamando a atenção uma dissertação que não cita sua concepção de Psicopedagogia.

Fazendo uma análise cronológica das concepções adotadas nessas dissertações e teses, observamos que algumas tendências permaneceram ao longo desses anos como: Psicopedagogia entendida como prática que procura estudar e resolver problemas de 
aprendizagem levando em conta os aspectos orgânicos, cognitivos, afetivos e sociais. A década de 80 de uma maneira geral revelou esta tendência. Mas no final dessa década, em 1989, aparece pela primeira vez a preocupação em fazer uma análise das concepções da Psicopedagogia ao invés de adotá-las apenas da maneira aleatória.

Nos anos 90 notamos uma preocupação na primeira metade da década de se estudar as concepções da Psicopedagogia seguindo a tendência que começou a aparecer em 1989, ou ainda, é quando há uma percepção de que faltam concepções ou definições que dê unidade a esta área, havendo inclusive uma das dissertações que aponta para a falta de concepções e definição para a área. Concepções que entendem a Psicopedagogia como área que estuda ou resolve problemas de aprendizagem continuam a aparecer nos demais trabalhos.

Na segunda metade da década de 90 observamos uma preocupação crescente em diferenciar a Psicopedagogia das demais áreas do conhecimento, seja mostrando que ela engloba diversas áreas como Psicologia, Pedagogia, Fonoaudiologia etc, seja dizendo explicitamente que é uma ciência autônoma. Nessa fase, também aparece na maior parte das definições a Psicopedagogia como área que se encarrega da prevenção dos problemas de aprendizagem, o que acaba revelando que mesmo no final do século, ainda assim a Medicina tem um poder sobre as demais ciências, ou seja, o problema de aprendizagem ainda é entendido nesse contexto, tendo que ser prevenido pela Psicopedagogia da mesma forma que a Medicina faz com as doenças, mostrando que não houve um avanço no sentido de se entender problemas de aprendizagem a partir de um contexto crítico da sociedade. Vale lembrar que na maior parte dos trabalhos, eles fazem questão de criticar a abordagem orgânica dos problemas de aprendizagem e citar a importância dos fatores emocionais, 
cognitivos e sociais. Mas acabam por adotarem como concepção aquilo que eles mesmos criticam. Em apenas quatro trabalhos de 24, a crítica do discurso psicopedagógico se cumpriu.

Na tabela 15a são apontados os principais objetivos das dissertações e teses selecionadas para esta pesquisa.

TABELA 15a - Frequiência e proporção de dissertações e teses, segundo os objetivos traçados nas pesquisas da ANPED.

\section{Objetivos}

Elaborar proposta psicopedagógica

Conceituar e diagnosticar os problemas de aprendizagem de determinado(s) aluno(s)

Estruturar a Psicopedagogia como campo de conhecimento prático, docente e clínico; buscar uma fundamentação teórica para a Psicopedagogia

Analisar aspectos como a formação, perfil, objeto de trabalho do psicopedagogo, os meios, locais e relações de trabalho

Identificar a situação existencial do idoso de classe média

Buscar as idéias de Piaget sobre aprendizagem nos documentos e relatos sobre a prática psicopedagógica na escola relativa a uma determinada Secretaria da Educação

Verificar se atividades de "domínio espacial” produzem efeitos na superação do egocentrismo infantil

Analisar discurso psicopedagógico

Opiniões de alunos sobre o curso de Psicopedagogia

Total

\section{frequência proporção}

06

0,3

03

0,2

02

0,1

02

0,1

01

0,0

01

0,0

01

0,0

$01 \quad 0,0$

$01 \quad 0,0$

1801

Dentre os objetivos apresentados nas dissertações e teses que estão na tabela 15a, o mais freqüente de todos $(0,3)$ foi elaborar proposta psicopedagógica para aplicação, seja com um aluno específico, seja na escola ou outra instituição. Este tipo de objetivo é coerente com aquilo que a Psicopedagogia se propõe: uma área de conhecimento com ênfase na prática. Na elaboração de uma proposta, a intenção neste tipo de objetivo é a 
aplicação prática, em conformidade com aquilo que no momento a sociedade elege como mais importante: soluções eficientes e práticas. Neste caso, a Psicopedagogia seria vista como uma técnica para prevenir ou resolver problemas de aprendizagem. O psicopedagogo previne, cura problemas e distúrbios de aprendizagem por meio de propostas elaboradas com finalidade prática.

Outro tipo de objetivo que apareceu nos trabalhos com maior freqüência $(0,2)$ foi conceituar e diagnosticar os problemas de aprendizagem de determinado(s) aluno $(s)$ revelando por um lado um interesse teórico no assunto, mas por outro, objetivos práticos. Não queremos dizer que haja problema em se traçar um perfil mais relacionado com a prática. O problema é uma prática sem uma prévia reflexão ou a falta de uma reflexão seguida da prática de maneira a reproduzir aquilo que já se encontra instalado no âmbito educacional. Embora sejam diferentes uns dos outros, podemos fazer as seguintes observações sobre os outros objetivos: uma preocupação em dar uma identidade à psicopedagogia e conseqüentemente ao profissional psicopedagogo, considerando que é uma área de conhecimento nova. Isto pode ser observado nos objetivos "traçar o perfil do psicopedagogo", “opinião dos alunos sobre o curso de Psicopedagogia", "estruturar a Psicopedagogia como campo de conhecimento prático, docente e clínico; buscar uma fundamentação teórica para a Psicopedagogia”. O que acaba chamando a atenção é que se essa identidade precisa ser buscada e construída é porque de certa forma ela ainda não existe, portanto, ainda não podendo ser entendida como área de conhecimento autônoma que se estende além da Psicologia e Pedagogia.

Um outro tipo de objetivo que apareceu dentre esses foi analisar o discurso pedagógico a respeito da "adolescência", levando em conta seus aspectos históricos, para 
apontar sua fragilidade quando não se leva em conta os aspectos sócio históricos, o único objetivo que revela uma preocupação mais crítica em relação ao assunto abordado.

Por fim, temos três outros objetivos mais específicos às referentes teses com apenas uma aparição: identificar a situação existencial do idoso de classe média, verificar se atividades de "domínio espacial" produzem efeitos na superação do egocentrismo infantil e buscar as idéias de Piaget sobre aprendizagem nos documentos e relatos sobre a prática psicopedagógica na escola, relativa a uma determinada Secretaria da Educação. Vale lembrar que o primeiro deles foi acompanhado de um segundo objetivo no mesmo, de trabalho de elaboração e aplicação de uma proposta pedagógica direcionada para esta população reafirmando mais uma vez a tendência para adotarem esse tipo de objetivo.

Na tabela $15 b$ temos a freqüência e proporção dos objetivos traçados nas dissertações e teses analisadas dos programas de Pós-graduação das faculdades de Psicologia.

TABELA 15b - Freqüência e proporção de dissertações e teses segundo os objetivos traçados nas pesquisas dos programas de pós-graduação das faculdades de Psicologia

\section{Objetivos}

- Conceituar e diagnosticar os problemas de aprendizagem de determinado(s) aluno(s)

- Descrever "esquemas" comuns utilizados pela criança no processo de construção de dois sistemas simbólicos

- Rever o conceito de conhecimento na obra de Freud para estabelecer seus desdobramentos no contexto da psicose infantil

\section{frequência proporção}

$01 \quad 0,2$

$01 \quad 0,2$

$01 \quad 0,2$ 


\begin{tabular}{ccc}
\hline - Demonstrar a eficiência do trabalho de Oficina Criativa & 01 & 0,2 \\
$\begin{array}{l}\text { - Analisar a construção do conhecimento por intermédio de aspectos } \\
\text { operatórios e individuais e de relações inter individuais }\end{array}$ & 01 & 0,2 \\
$\begin{array}{c}\text { - Comparar a realização de crianças retardadas mentais em uma prova } \\
\text { de prontidão e uma de percepção visomotora com o desempenho } \\
\text { num material de ensino de leitura em nível e alfabetização } \\
\text { Total }\end{array}$ & 01 & 0,2 \\
& $\mathbf{0 6}$ & $\mathbf{0 1}$ \\
\hline
\end{tabular}

Para os trabalhos apresentados no curso de pós-graduação das faculdades de Psicologia não houve uma tendência nos objetivos traçados nos trabalhos. Dos seis trabalhos analisados houve seis objetivos diferentes entre si, embora seja importante lembrar que em um deles se repete a tendência da elaboração da proposta pedagógica com máxima frequência nos objetivos das dissertações e teses da ANPED. No entanto, nesse caso a proposta já está elaborada; ela apenas terá que ser aplicada para ser comprovada, tentando se aproximar do tipo de pesquisa positivista na qual é realizado um experimento e ele pode ou não ser comprovado. Nos demais trabalhos o que chama a atenção é a especificidade de seus objetivos caminhando principalmente em duas linhas teóricas: piagetiana e psicanalítica. Esses trabalhos constam da aplicação desses referenciais para comprovação de algum tipo de objetivo prático traçado.

$\mathrm{Na}$ tabela 15c temos a freqüência e proporção dos objetivos traçados nas dissertações e teses analisadas dos programas de Pós-graduação das faculdades de Educação.

TABELA 15c - Freqüência e proporção de dissertações e teses segundo os objetivos traçados nas pesquisas dos programas de pós-graduação das faculdades de Educação

\begin{tabular}{lcc}
\hline \multicolumn{1}{c}{ Objetivos } & frequência & proporção \\
Elaborar proposta psicopedagógica & 01 & 0,3 \\
Analisar os campos semântico-conceptual e léxico-semântico & 01 & 0,3 \\
Discutir os limites da psicopedagogia quando não se leva em & 01 & 0,3 \\
consideração o Inconsciente da Psicanálise. & & \\
\hline
\end{tabular}


Nos cursos de pós-graduação das faculdades de Educação vemos um trabalho que foca o objetivo de elaborar uma proposta psicopedagógica repetindo o padrão anterior. Temos um trabalho que relaciona Psicanálise com Psicopedagogia e um trabalho mais voltado para objetivos da Lingüística: analisar os campos semântico-conceptual e léxicosemântico.

Buscando mais uma vez uma tendência cronológica, temos na década de 80 uma frequiência maior de trabalhos que procuram como objetivos nas dissertações e teses algum tipo de proposta psicopedagógica que vise uma aplicação prática. Com exceção de uma dissertação que apresenta um objetivo mais específico - verificar se atividades de "domínio espacial" produzem efeitos na superação do egocentrismo infantil e de um trabalho defendido em 1989, ou seja, um trabalho com uma tendência mais próxima dos anos 90, todos os outros de alguma forma apresentam algum tipo de proposta para colaboração com a nova área de conhecimento. Este último trabalho tem seu objetivo mais coerente com a tendência apresentada na primeira metade da década de 90 .

Na primeira metade da década de 90 aproximadamente, todos os trabalhos analisados tinham como objetivo a preocupação em fundamentar ou analisar a Psicopedagogia enquanto área de conhecimento ou aspectos como a formação, perfil, objeto de trabalho do psicopedagogo, os meios, locais e relações de trabalho. Parece um momento em que os autores se preocupam com uma diferenciação da Psicopedagogia em relação a outras áreas do conhecimento, é uma busca da identidade da área em questão a partir de opiniões, de alunos de cursos de especialização, profissionais da área e dados teóricos, de uma maneira a deixar de entender a Psicopedagogia de maneira intuitiva e passar a olhá-la com identidade própria. Na segunda metade da década, volta a tendência em elaborar propostas psicopedagógicas para aplicação principalmente nas escolas com 
alunos que apresentam problemas de aprendizagem ou com intenção preventiva parecendo haver uma intenção de "provar" que a Psicopedagogia "funciona". Com exceção de dois trabalhos com objetivos mais específicos de analisar o discurso pedagógico de maneira mais reflexiva, todos os outros apresentam a tendência anterior apresentada.

A seguir temos a tabela 16a que traz os tipos de pesquisa (empírica ou teórica) realizados nas dissertações e teses da $A N P E D$ selecionadas para esta pesquisa.

TABELA 16a - Freqüência e proporção de dissertações e teses da ANPED segundo o tipo de pesquisa realizada

\section{Tipo de pesquisa}

Empírica

Teórica

Total

\section{frequência}

09

06

15 proporção

0,6

0,4

01

Dentre os tipos de pesquisa utilizados nas dissertações e teses analisadas podemos observar na tabela 16a que predominou a empírica, ou seja, nove dos $15(0,6)$ trabalhos são pesquisas empíricas e seis $(0,4)$ foram pesquisas teóricas. Ou ainda, olhando para todos os trabalhos em conjunto temos 16 pesquisas empíricas para oito teóricas. Fica evidente a tendência da pesquisa empírica nos trabalhos, ou seja, aproximadamente dois terços deles optaram por um tipo de pesquisa empírica o que é condizente com o que já discutimos sobre a área de conhecimento psicopedagógica que se pretende uma prática e cada vez mais se adequar ao tipo de sociedade vigente.

A tabela 16b traz os tipos de pesquisa (empírica ou teórica) realizados nas dissertações e teses dos programas de Pós-graduação das faculdades de Psicologia selecionadas para esta pesquisa. 
TABELA 16b - Frequiência e proporção de dissertações e teses dos programas de pós-graduação das faculdades de Psicologia segundo o tipo de pesquisa realizada

\begin{tabular}{lccc}
\hline & Tipo de pesquisa & frequência & proporção \\
Empírica & & 05 & 0,8 \\
Teórica & Total & 01 & 0,2 \\
& \multirow{2}{*}{ Tot } & $\mathbf{0 6}$ & $\mathbf{0 1}$ \\
\hline
\end{tabular}

A mesma tendência se repete com os trabalhos da Psicologia PUC e USP: 0,8 constam de pesquisas empíricas e 0,2 representando uma pesquisa teórica.

A tabela 16c traz os tipos de pesquisa (empírica ou teórica) realizados nas dissertações e teses dos programas de Pós-graduação das faculdades de Educação selecionadas para esta pesquisa.

TABELA 16c - Freqüência e proporção de dissertações e teses dos programas de pós-graduação das faculdades de Educação segundo o tipo de pesquisa realizada

Tipo de pesquisa $\quad$ frequência $\quad$ proporção

Empírica

$02 \quad 0,7$

Teórica

$01 \quad 0,3$

Total

03

01

Mais uma vez aqui a tendência empírica se repete, com a proporção de 0,3 para pesquisas teóricas e 0,7 para pesquisas empíricas.

Como tendência cronológica, temos nos anos 80 todas as pesquisas com exceção da última defendida em 1989, como pesquisa do tipo empírica. Até a metade da década de 90 houve um aumento das pesquisas do tipo teórica, mas no entanto a marca da prática refletido nas pesquisas empíricas continua aparecendo e esta tendência volta a crescer a 
partir da segunda metade da década de 90 até início do novo século. Essas pesquisas do tipo empírica na grande maioria das vezes são típicas pesquisas positivistas sem procurar atentar para uma reflexão voltada para um questionamento da área estudada. Essas pesquisas são na maior parte das vezes para confirmar ou justificar os próprios conceitos da Psicopedagogia.

A seguir temos a tabela 17a que mostra a freqüência e proporção de dissertações e teses da ANPED segundo o referencial teórico adotado.

TABELA 17a - Freqüência e proporção de dissertações e teses da ANPED segundo o referencial teórico adotado

\section{Referencial teórico/autor}

Epistemologia Genética (Piaget)

Epistemologia Convergente de Jorge Visca

Sócio-interacionismo de Vygotsky

Alicia Fernandez/Sarah Pain

outros $^{34}$

Não adota frequência

03

02

02

02

01

01

19

30 proporção

0,1

0,1

0,1

0,1

0,0

0,0

0,6

Total

O referencial teórico mais utilizado foi a Epistemologia Genética de Jean Piaget, em três trabalhos, seguida da Epistemologia Convergente de Jorge Visca (dois trabalhos), do Sócio-interacionismo de Vygotsky (dois trabalhos) e Alicia Fernandez/ Sarah Pain (dois

\footnotetext{
${ }^{34}$ Outros refere-se à dissertação que entrevistou diversos autores e que precisou citá-los no seu referencial teórico.

- Referenciais ou autores utilizados apenas uma vez nos trabalhos analisados: Psicomotricidade Relacional de Lapierre, Pedagogia de Freinet, Rich, De La Puente, Rogers, Gestalt terapia, Wallon, Erikson, Paulo Freire, Bruner, Fonseca, Valett, Ausubel, Weiss, Macedo, Hoose et Worth Vaillant, Figueiredo, Figueira, Vasconcelos, Parrat-Dayan.
} 
trabalhos). Os demais autores e referenciais teóricos apareceram na mesma proporção, uma aparição. Vale lembrar que o referencial da Epistemologia Genética embora só apareça em três trabalhos como referencial, ele é citado e comentado em praticamente todos os trabalhos.

Com exceção de alguns autores que deixam bem especificado seu referencial teórico, os demais utilizaram diversos referenciais no mesmo trabalho. Como podemos observar na tabela, há mais itens com autores e referenciais teóricos do que o número de trabalhos analisados. Na maior parte das vezes, ao invés de seguirem um referencial apenas, houve uma tendência de se citar vários autores com pensamentos diversos e em alguns casos antagônicos em um mesmo trabalho. Houve uma tentativa de procurar mais mostrar o que cada autor pensa sobre aprendizagem ou demais assuntos, do que utilizá-los para fazer uma análise da pesquisa em questão.

No trabalho "A invenção da adolescência no discurso psicopedagógico", embora o autor tenha utilizado vários autores, o fez para delinear contextos históricos e foram autores que convergem de uma certa forma em termos teóricos.

No trabalho "Psicopedagogia: um perfil profissional em conflito", a autora entrevistou diversos profissionais da área que são autores também (Lino de Macedo, Alicia Fernandez, Elcie Fazano Massini, Marta Khol, Maria Helena Novaes, Aglael Borges, Maria Luiza Gomes Pereira, Ana Maria de Castro Magioli, Celma Vilaça, Wilma Barata Barbosa, Fany Plaschta, Sonia Fonseca, Maria Célia Rosetto, Haydée Mayae), portanto, teve de citar todos os entrevistados em seu referencial teórico. 
Outro fato comum foi o autor apresentar um referencial teórico como adotado, mas no decorrer do trabalho ele acabar utilizando outro referencial que não aquele primeiro. Por exemplo, no trabalho Psicopedagogia Inter-Ativa: ação psicopedagógica institucional baseada em uma convergência teórica, o referencial utilizado engloba quatro teorias de diferentes autores mas que possuem aspectos semelhantes segundo a autora do trabalho. Esses autores apresentam aspectos comuns como, por exemplo, a importância que dão a adaptação à realidade. O produto deve ser um indivíduo autônomo preparado para agir e transformar com consciência (Maman, 1997). No entanto, não é explicado o que estes autores entendem por autonomia e em que direção deve se dirigir tal transformação, além de não se especificar também, qual o tipo de consciência que o indivíduo deve atingir. Mais do que isto, no decorrer do trabalho observamos que ele não caminha no sentido que conduza os alunos à autonomia. Embora ela adote esse referencial teórico, vemos durante o trabalho a utilização constante da Epistemologia Genética de Jean Piaget, utilizando diversas citações. Parece que esse referencial acaba dando suporte a ela para embasar suas hipóteses sobre fracasso escolar do que os outros que ela explicita como sendo referenciais adotados. Fica evidente também que muitas das explicações que ela dá para os problemas de aprendizagem têm suporte na Teoria da Carência Cultural. Vemos uma miscelânea de referenciais num mesmo trabalho desarticulados uns com os outros e sem a utilização de nenhuma crítica em relação a eles.

A falta de questionamento dos referenciais teóricos também ocorre, por exemplo com o autor Jorge Visca que defende como pré requisito para o sucesso na aprendizagem a resolução das ansiedades e a adaptação ativa à realidade, a criatividade, projetos etc. A aprendizagem, segundo Visca, para a autora: "somatória de informação dos integrantes do grupo, transformação de quantidade em qualidade. Resolução de ansiedades, adaptação 
ativa à realidade, criatividade, projetos, etc”. Fica a pergunta: é possível ser criativo quando só há espaço para a adaptação? Este seria um dos questionamentos possíveis, mas que não ocorre no trabalho. Parece que a criatividade acaba aparecendo mais como uma obrigação para adaptação por mais contraditório que isso pareça. A autora acaba partindo de um princípio que destoa do autor escolhido.

A seguir temos a tabela $17 \mathrm{~b}$ que mostra a frequiência e proporção de dissertações e teses dos programas de Pós-graduação das faculdades de Psicologia segundo o referencial teórico adotado.

TABELA 17b - Frequiência e proporção de dissertações e teses dos programas de pós-graduação das faculdades de Psicologia segundo o referencial teórico adotado

\begin{tabular}{|c|c|c|}
\hline Referencial teórico/autor & frequência & proporção \\
\hline Epistemologia Genética (Piaget) & 03 & 0,3 \\
\hline \multirow[t]{2}{*}{ Psicanálise Freud/Lacan } & 02 & 0,2 \\
\hline & 05 & 0,5 \\
\hline Total & 10 & 01 \\
\hline
\end{tabular}

Como no caso dos trabalhos da ANPED, o referencial mais utilizado foi a Epistemologia Genética de Jean Piaget $(0,3)$. Em seguida a maior aparição foi para a Psicanálise de Freud e Lacan $(0,2)$ e Psicologia Analítica de Jung, Psicodrama de Moreno e Witter, Copit e Poppovic sendo utilizados uma vez apenas nos trabalhos. Aqui também encontramos referenciais e autores acima do número de trabalhos analisados. Mas aqui houve uma tendência de serem mais coerentes com os autores utilizados e com a pesquisa realizada.

\footnotetext{
- Referenciais ou autores utilizados apenas uma vez nos trabalhos analisados: Psicologia Analítica de Jung, Psicodrama de Moreno, Witter, Copit e Poppovic.
} 
A seguir temos a tabela 17c que mostra a freqüência e proporção de dissertações e teses dos programas de Pós-graduação das faculdades de Educação segundo o referencial teórico adotado.

TABELA 17c - Freqüência e proporção de dissertações e teses dos programas de pós-graduação das faculdades de Educação segundo o referencial teórico adotado

\begin{tabular}{lcc}
\hline \multicolumn{1}{c}{ Referencial teórico/autor } & frequência & proporção \\
Epistemologia Genética (Piaget) & 01 & 0,2 \\
Construtivismo de Piaget/ Emila Ferreiro/ Teberosky & 01 & 0,2 \\
Psicanálise de Freud/Lacan & 01 & 0,2 \\
Psicopedagogia de Alicia Fernandez & 01 & 0,2 \\
Gutierrez, Snyders, Kneller e Pais, Barbosa, Genouvrier, & 01 & 0,2 \\
Pottier, Robin & & 0,2 \\
Sarah Pain & 01 & $\mathbf{0 1}$ \\
TOTAL & $\mathbf{0 6}$ & \\
\hline
\end{tabular}

Aqui, todos os referenciais citados na tabela apareceram em igual proporção, chamando a atenção novamente para o fato de serem utilizados mais referenciais e autores do que o número de trabalhos analisados.

Cronologicamente não é possível estabelecer tendências teóricas utilizadas nas diferentes décadas analisadas. Mesmo os autores mais utilizados distribuem-se de uma maneira desigual dentro das décadas de 80, 90 e nos anos 2000 e 2001.

Segundo Szterling (2000) a Psicopedagogia não possui ainda um campo teórico sistematizado. Os profissionais dessa área utilizam diversas abordagens ou partes dessas abordagens para poder fundamentar seu trabalho clínico ou institucional. Bossa (2000) observa que mesmo nos cursos de especialização em Psicopedagogia no Brasil, ainda não há um conteúdo programático ou estrutura curricular comum, embora 
podemos ver um maior destaque para autoras como Sarah Pain e Alicia Fernandez nesses cursos. Conforme Szterling citando Vorcaro: "hoje existem [no Brasil] tantas psicopedagogias quantos psicopedagogos”(SZTERLING, 2000:08).

A tabela 18a mostra as conclusões elaboradas pelos autores das dissertações e teses analisadas da $A N P E D$. Mais uma vez, a frequiência da tabela é relativa às conclusões e não ao número de trabalhos analisados.

TABELA 18a - Dissertações e teses da ANPED segundo as conclusões tiradas nas pesquisas em dados brutos e proporção

\section{Conclusões}

- Distúrbios de aprendizagem são causados por fatores emocionais, orgânicos, sociais (família), pedagógicos (escola), econômicos

- Professores precisam de melhor formação

- A Psicopedagogia deve se ater à prática

- Psicopedagogia como nova área que preenche falta entre Psicologia e Pedagogia

- Discurso psicopedagógico trata a adolescência como um universal ahistórico e natural/Psicopedagogia não é natural, mas é produzida por uma dinâmica social

- Psicopedagogia como campo de atuação interdisciplinar e multidisciplinar

- Proposta psicopedagógica de desenvolver diversas potencialidades que são requisitos para a aprendizagem é viável e necessária

- A prática na Secretaria da Educação se desenvolveu numa proposta eclética sobressaindo a matriz romântica

- Reflexão como um ato importante para compreender fenômenos diferenciando o que é dificuldade de aprendizagem do que é aprendizagem normal

- Psicopedagogia possibilita autoconhecimento

- Não há identidade entre Psicopedagogia e psicopedagogos

- O olhar da psicopedagogia se condensa nas modalidades de

\section{frequência proporção}

$04 \quad 0,2$

$03 \quad 0,1$

020,1

$02 \quad 0,1$

$02 \quad 0,1$

$02 \quad 0,1$

$02 \quad 0,1$

$01 \quad 0,0$

$01 \quad 0,0$

$01 \quad 0,0$

$01 \quad 0,0$

$01 \quad 0,0$ 


\begin{tabular}{|c|c|c|}
\hline \multicolumn{3}{|l|}{ aprendizagem } \\
\hline $\begin{array}{l}\text { - As atividades de "domínio espacial" produzem efeitos na superação } \\
\text { do egocentrismo infantil }\end{array}$ & 01 & 0,0 \\
\hline $\begin{array}{l}\text { - Psicopedagogia com falta de nitidez conceitual e em estado de pré- } \\
\text { saber }\end{array}$ & 01 & 0,0 \\
\hline - O atendimento psicopedagógico se mostrou eficaz & 01 & 0,0 \\
\hline $\begin{array}{l}\text { - Os idosos entrevistados não apresentam problemas de alimentação, } \\
\text { mas apresentam problemas de saúde. O aspecto social tem } \\
\text { influência sobre a velhice. Os idosos consideram a assistência } \\
\text { familiar como prioritária. }\end{array}$ & 01 & 0,0 \\
\hline - Psicopedagogia mais evoluída na Argentina do que no Brasil & 01 & 0,0 \\
\hline $\begin{array}{l}\text { - Os cursos de Psicopedagogia não cumprem as idéias da } \\
\text { Psicopedagogia principalmente em relação à afetividade }\end{array}$ & 01 & 0,0 \\
\hline Total & 28 & 01 \\
\hline
\end{tabular}

Segundo dados da tabela 18a, observamos as diversas conclusões. Dentre elas, a que apareceu numa maior proporção foi que distúrbios de aprendizagem são causados por fatores emocionais, orgânicos, sociais (família), pedagógicos (escola), econômicos em quatro trabalhos dos 15; a seguir temos em três dos 15 trabalhos que os professores precisam de melhor formação. Com duas aparições considerando os 15 trabalhos tivemos as seguintes conclusões: Psicopedagogia como nova área que preenche falta entre Psicologia e Pedagogia; Proposta psicopedagógica de desenvolver diversas potencialidades que são requisitos para a aprendizagem é viável e necessária; Discurso psicopedagógico trata a adolescência como um universal a-histórico e natural/Psicopedagogia não é natural, mas é produzida por uma dinâmica social; Psicopedagogia como campo de atuação interdisciplinar e multidisciplinar; A Psicopedagogia deve se ater à prática. As demais conclusões apareceram em apenas um dos trabalhos analisados. A maior parte delas acaba por expressar os próprios conceitos da Psicopedagogia. É como se os trabalhos realizados fossem feitos para reafirmar os próprios 
conceitos já instalados pela Psicopedagogia. Os autores acabam por enxergar em seus experimentos aquilo que não tem a intenção de contestar. Os únicos casos em que este tipo de conclusão não aparecem foram em trabalhos que procuraram ser mais reflexivos e que chegaram a conclusões mais críticas como: discurso psicopedagógico trata a adolescência como um universal a-histórico e natural/Psicopedagogia não é natural, mas é produzida por uma dinâmica social e a prática na Secretaria da Educação se desenvolveu numa proposta eclética sobressaindo a matriz romântica. No entanto vale lembrar que isso só ocorreu em três de 15 trabalhos. Um deles, por exemplo, que caminhou nessa direção mais crítica, apontou para a fragilidade do termo "adolescência" quando utilizado no discurso psicopedagógico sem levar em consideração seu aspecto histórico, além de mostrar que normalmente esse termo é utilizado na psicopedagogia de maneira a-histórica e natural.

O maior número de conclusões vão na mesma direção da Psicopedagogia, confirmando seu discurso de que os problemas de aprendizagem advêm de fatores emocionais, orgânicos, socioculturais e pedagógicos e em outra, que a Psicopedagogia vem para suprir a falta que há na Psicologia e Pedagogia além de propiciar autoconhecimento. Essas duas conclusões foram tiradas a partir do próprio discurso teórico psicopedagógico.

Algumas conclusões chamam a atenção no sentido do que foi concluído; aspectos que o trabalho como um todo não se propôs e não analisou. Ou seja, fica o estranhamento de como o autor chegou àquela conclusão. Um exemplo são os dois trabalhos que concluem que a Psicopedagogia deve se ater à prática. Não fica claro que tipo de pesquisa foi feita para se chegar a esta conclusão. Aqui mais uma vez percebemos a repetição do 
discurso psicopedagógico como conclusão, independentemente se houve dados que confirmassem este aspecto ou não na pesquisa realizada.

Em outra conclusão, é apontada a importância da reflexão para se diferenciar o que é um problema de aprendizagem do que é uma aprendizagem normal. Como já foi dito anteriormente, a reflexão é um ato muito importante em qualquer trabalho científico. No entanto, neste caso, a reflexão foi utilizada de maneira a diferenciar padrões préestabelecidos. Seria interessante poder refletir sobre estes padrões e os critérios para o estabelecimento dos mesmos.

Houve um grupo de conclusões mais específicas que vieram de trabalhos com objetivos mais específicos também, por exemplo, um trabalho que aborda problemas vivenciados por pessoas da terceira idade.

A tabela 18b mostra as conclusões elaboradas pelos autores das dissertações e teses analisadas do programa de pós-graduação das faculdades de Psicologia.

TABELA 18b - Dissertações e teses do programa de pós-graduação das faculdades de Psicologia segundo as conclusões tiradas nas pesquisas em dados brutos e proporção

\section{Conclusões}

frequência

proporção

- Psicanálise pode contribuir para a psicopedagogia

01

0,2 


\begin{tabular}{|c|c|c|}
\hline $\begin{array}{l}\text { - Ambos os esquemas tratados no trabalho não são totalmente } \\
\text { autônomos e podem servir como suporte para um trabalho } \\
\text { psicopedagógico que procure fortalecer um domínio simbólico } \\
\text { ainda não bem desenvolvido. }\end{array}$ & 01 & 0,2 \\
\hline $\begin{array}{l}\text { - As performances das crianças nos jogos apontaram a mesma direção } \\
\text { das respostas obtidas nas duas aplicações das provas operatórias e } \\
\text { no segundo experimento, as intervenções puderam possibilitar a } \\
\text { construção do conhecimento. }\end{array}$ & 01 & 0,2 \\
\hline $\begin{array}{l}\text { - A Oficina Criativa ajuda experienciar a aprendizagem de forma a } \\
\text { ampliá-la. }\end{array}$ & 01 & 0,2 \\
\hline $\begin{array}{l}\text { - Há três eixos referenciais para a análise das relações entre psicose } \\
\text { infantil e conhecimento }\end{array}$ & 01 & 0,2 \\
\hline $\begin{array}{l}\text { - Crianças consideradas retardadas mentais alunas da APAE podem } \\
\text { aprender a ler num ritmo próprio e com métodos especiais que não } \\
\text { necessariamente são aqueles impostos pela elite cultural. }\end{array}$ & 01 & 0,2 \\
\hline Total & 06 & 01 \\
\hline
\end{tabular}

Nas conclusões da pós-graduação das faculdades de Psicologia não houve nenhuma que teve uma frequência superior às demais, uma vez que todas elas foram mais específicas de acordo com o objetivo proposto pelos trabalhos. A diferença que notamos em relação às conclusões dos trabalhos das outras tabelas é que nenhum deles procura confirmar o discurso pedagógico no sentido de repeti-lo. Isso não quer dizer que não haja críticas a serem feitas em relação a essas conclusões.

A tabela 18c mostra as conclusões elaboradas pelos autores das dissertações e teses analisadas do programa de pós-graduação das faculdades de Educação.

TABELA 18c - Dissertações e teses do programa de pós-graduação das faculdades de Educação segundo as conclusões tiradas nas pesquisas em dados brutos e proporção

\section{Conclusões}

- Psicanálise pode contribuir para a psicopedagogia
Freqüiência proporção

$01 \quad 0,3$ 


\begin{tabular}{lll}
\hline - Psicologia genética pode contribuir para a psicopedagogia & 01 & 0,3 \\
$\begin{array}{l}\text { Os temas preferidos pelos alunos devem ser considerados na seleção } \\
\text { de conteúdos que a escola realiza de forma a ampliar o léxico }\end{array}$ & 01 & 0,3 \\
individual dos alunos. & 01 & 0,3 \\
$\begin{array}{l}\text { - Toda criança é capaz de aprender, logo deve-se discutir como vem } \\
\text { sendo conduzido o processo ensino aprendizagem do aluno na } \\
\text { escola }\end{array}$ & $\mathbf{0 4}$ & $\mathbf{0 1}$ \\
\hline
\end{tabular}

Na tabela 18c também não temos conclusões que apareçam em mais de um trabalho. Chamam a atenção as conclusões que procuram mostrar que outras áreas de conhecimento ou referenciais podem contribuir para a Psicopedagogia como a Psicanálise e a Psicologia Genética.

Cronologicamente não observamos na década de 80 nenhuma tendência específica. O que é possível ver é a partir de 1989 o aparecimento de trabalhos preocupados com conclusões mais reflexivas, algumas procurando questionar a Psicopedagogia enquanto área de conhecimento ou seu discurso, mas na maior parte das vezes concluem uma reafirmação daquilo que a Psicopedagogia defende, em outras vezes, tentam justificar certos pressupostos como, por exemplo, no trabalho que diz que a Psicopedagogia não está bem fundamentada pois ela se encontra num estágio de pré-saber, logo ficando subentendido que um dia se tornará um saber. Em outros casos, poucos infelizmente, os autores conseguem chegar a uma conclusão mais crítica dando margem a um possível avanço na área como já comentado em parágrafos anteriores.

A tabela 19a traz o número e proporção de dissertações e teses que apresentam os termos adaptação e emancipação nos trabalhos da ANPED.

TABELA 19a - Freqüência e proporção de dissertações e teses da ANPED que apresentam os termos adaptação e emancipação

frequência proporção




\begin{tabular}{ccc}
\hline Adaptação & 10 & 0,6 \\
Emancipação & 03 & 0,2 \\
Não cita adaptação e & 03 & 0,2 \\
emancipação & & \\
Total & $\mathbf{1 6}$ & $\mathbf{0 1}$ \\
\hline
\end{tabular}

Como podemos observar, a palavra adaptação foi citada em 10 dos 15 trabalhos analisados. Nos 10 trabalhos, a palavra adaptação aparece na maior parte das vezes no capítulo referente a teoria utilizada e/ou na parte histórica da dissertação ou tese, como uma das facetas da Educação, ou seja, um dos objetivos da Educação é o de adaptar os indivíduos à sociedade ou no sentido defendido pela Epistemologia Genética como sendo a adaptação o mecanismo que possibilita sobrevivência. Em um dos trabalhos a palavra aparece para lembrar que a escola brasileira se baseou - se adaptou - ao modelo europeu de escola e educação. Até então o termo aparece para descrever questões históricas ou conceituais relacionadas à Educação e não demonstraram se o autor do trabalho concorda ou não com apenas este tipo de postura em educação. "Não podemos, no entanto, esquecer que a educação tem outro sentido, o de atuar sobre a pessoa, para torná-la capaz e adaptar-se a um modelo previamente escolhido" (ZILIO, 1993:15). Neste outro trabalho a palavra adaptação aparece em um sentido mais preocupado com a crítica: “A crítica e a denúncia do caráter adaptativo das práticas psicológicas invadem a literatura dos anos 80... (BECKER, 1998:101)”. Nesse trabalho a palavra adaptação aparece em um contexto histórico, mas a autora se utiliza desse contexto para fazer críticas pertinentes à Psicologia e Pedagogia dos anos 80. Nesse mesmo trabalho aparece o termo emancipação também em um tom reflexivo: "será que o fato de se criarem condições para o desenvolvimento da reciprocidade e da cooperação, em sala de aula, significa que a escola possa tornar-se um instrumento poderoso de emancipação e de desalienação, a ponto de promover mudanças 
estruturais na sociedade?" (BECKER, 1998:101). A autora também discute os termos heteronomia e autonomia mas não segundo o referencial de Adorno.

Em mais dois trabalhos aparece o termo emancipação explicitado. A dissertação "Atendimento psicopedagógico e as dificuldades de aprendizagem" cita ambos os termos (adaptação e emancipação). Em uma delas, a palavra adaptação aparece num sentido daquele utilizado na teoria da carência cultural: "A escola terá que adaptar-se às crianças, à variedade humana" (SGARBOSSA, 1997:15). Ou ainda:

\footnotetext{
"O atual contexto escolar, é ineficiente às crianças que possuem dificuldades de aprendizagem, pois impossibilita a adaptação dos objetivos, em se fazer um ensino democrático, com decisão coletiva sobre os conteúdos de ensino, que representem os interesses dos alunos e que, principalmente, considere as necessidades de cada um. (SGARBOSSA, 1997:13)'”.
}

Em outro momento, ao citar as condições para que a aprendizagem ocorra, volta a usar o termo adaptação: "possuir boa adaptação pessoal e familiar" (SGARBOSSA, 1997:19). Finalmente, cita emancipação em uma frase que procura refletir sobre a teoria da alfabetização:

\footnotetext{
"Pensamos que no campo da teoria da alfabetização nada é mais importante do que olhar cuidadosamente a percepção do nosso perceber, de pensar sobre o pensamento, de interpretar nossas interpretações, pois comungamos a idéia de que a mesma é um projeto emancipador” (SGARBOSSA, 1997:16).
}

O outro trabalho que cita o termo emancipação é “A psicopedagogia no Brasil: contribuições a partir da prática" ao comentar as metas relacionadas à Psicopedagogia: " $a$ Psicopedagogia busca a sua emancipação, na porção em que investe na elaboração de um 
instrumento próprio, bem como se reforce por meio do estabelecimento de uma legislação mais precisa..." (BOSSA, 1993:122).

O mais freqüente foi o aparecimento de uma aparente defesa de uma educação para o "crescimento" e "desenvolvimento" do indivíduo, mas sem uma estruturação de como isso deveria se dar. No entanto, no decorrer de um dos trabalhos esta postura se mostra contraditória; a palavra adaptação acaba aparecendo para apontar o papel do psicopedagogo como um profissional que deve ajudar o aluno a se adaptar a escola e corresponder a suas expectativas. Matioda (1998) ao se referir ao trabalho do psicopedagogo escreve: "compreende-se que apesar de todo o esforço que o aluno dispensa, dificilmente conseguirá corresponder às expectativas escolares sem um apoio externo... A Psicopedagogia vem ajudar nessa inserção” (MATIODA, 1998:56). E no decorrer de seu trabalho continua confirmando essa posição ao comentar sobre o professor e o aluno em sala de aula e seus problemas:

"O professor que tiver em sua sala de aula alunos com problemas de aprendizagem estará diante da desafiadora tarefa de ajudálos a se adaptarem à escola. Esse tipo de criança não é necessariamente um deficiente intelectual. Existem outras causas que podem provocar a lentidão da aprendizagem como distúrbios emocionais, problemas físicos, falta de incentivo, hábitos inadequados de estudo, condições familiares estáveis e também deficiência do próprio ensino" (MATIODA, 1998:163).

É importante lembrar que a adaptação em termos de conhecimento da cultura e das regras racionais é um dos passos para uma posterior emancipação. Mas em nenhum dos trabalhos este aspecto foi discutido ou pelo menos citado. 
Houve três trabalhos em que não foram citados os termos adaptação e emancipação, revelando que para alguns autores estes temas não são fonte de interesse ou importância. No entanto, em um deles “A atuação do profissional em Psicopedagogia e a formação do psicopedagogo em São Paulo no período de 1980 a 1990”, que embora não cite os termos adaptação ou emancipação não defendendo explicitamente nenhuma das duas posições, é um trabalho voltado para uma educação emancipatória, pois ele não se contenta em apenas aplicar a teoria sem uma prévia reflexão. Pelo contrário, a autora faz um estudo da Psicopedagogia em São Paulo enquanto área de conhecimento e profissão de forma crítica, mostrando que da maneira que a Psicopedagogia está estruturada e é pretendida está servindo a interesses coorporativistas, ou seja, apontou seus aspectos regressivos e que não contribuem para uma educação emancipatória. No entanto, este item será melhor discutido nas tabelas 20a, 20b, 20c.

A tabela $19 b$ traz o número e proporção de dissertações e teses que apresentam os termos adaptação e emancipação do programa de Pós-graduação das faculdades de Psicologia.

TABELA 19b - Freqüência e proporção de dissertações e teses do programa de pós-graduação das faculdades de Psicologia que apresentam os termos adaptação e emancipação

Freqüência

04

02

00

06 proporção

0,7

0,3

00

01

Como podemos observar, em quatro dos seis trabalhos foi citado o termo adaptação. Em dois deles no sentido piagetiano do termo como já havia ocorrido com alguns trabalhos da ANPED: 


\begin{abstract}
"Já o jogo de construção tem o objetivo de possibilitar a reconstrução do real, seja ela por intermédio da construção de um objeto, de uma cena acontecida, de uma dramatização que encena a vida, a serviço de uma melhor adaptação à vida social, afetiva e ao trabalho". (WECHSLER, 1994:37)
\end{abstract}

No mesmo trabalho cita novamente o termo ao explicar a metodologia utilizada

\footnotetext{
“... mas sobretudo levar nossos sujeitos a tomarem consciência de seus próprios pensamentos, ou seja da função que eles estariam assumindo, o que poderia thes propiciar uma nova organização interna, expressada por uma melhor adaptação externa, por via de uma ação de jogar mais eficaz" (WECHSLER, 1994:60).
}

Em ambos os casos a palavra aparece como aplicação da teoria de Piaget.

No trabalho "Oficina criativa e psicopedagogia", o termo adaptação é utilizado como uma conquista obtida a partir da aprendizagem, mais uma vez com o lema - aprender para se adaptar: "acredito que um processo de aprendizagem, desenvolvido de forma criativa, permite ao indivíduo elaborar suas habilidades cognitivas de forma mais completa, o que pode ter um papel importante para ele ser, estar, sentir, visualizar, imaginar, aprender, adaptar-se e ser criativo na sua vida" (ALLESSANDRINI, 1995:55).

No trabalho "Um estudo psicanalítico sobre a produção do conhecimento na criança psicótica" o termo adaptação é utilizado para se referir aos parâmetros de ação utilizados na psicose infantil quando esta não é analisada junto ao que ele nomeia de discurso do conhecimento ou quando é analisada nas intersecções com o discurso do conhecimento: "As práticas e intervenções que aqui são engendradas tomam, como parâmetros de ação, as idéias de inadaptação e inadequação social, o que envolve a necessidade de afastamento e exclusão...”(LIMA, 1998:139) “...A criança psicótica, no 
entanto, permanece tomada enquanto objeto, sendo suas produções suportes de readaptações, na perspectiva de uma estrita retificação de seus conteúdos aos cânones da realidade" (LIMA, 1998:139-140).

Os outros dois trabalhos não utilizaram e não se preocuparam com questões referentes aos termos adaptação e emancipação.

A tabela 19c traz o número e proporção de dissertações e teses que apresentam os termos adaptação e emancipação do programa de Pós-graduação das faculdades de Educação.

TABELA 19c - Frequiência e proporção de dissertações e teses do programa de pós-graduação das faculdades de Educação que apresentam os termos adaptação e emancipação

\begin{tabular}{ccc}
\hline & frequência & proporção \\
Adaptação & 02 & 0,7 \\
Não cita adaptação e & 01 & 0,3 \\
emancipação & & \\
Emancipação & 00 & 00 \\
Total & $\mathbf{0 3}$ & $\mathbf{0 1}$ \\
\hline
\end{tabular}

Com exceção de um trabalho que não cita nenhum dos dois termos, os outros dois citam apenas o termo adaptação no sentido em que a Epistemologia Genética de Piaget utiliza: "A adaptação ocorre pelo equilibrio entre assimilação e acomodação". (TEIXEIRA, 1996:11). Este é um dos exemplos do uso do termo adaptação utilizado pela Epistemologia Genética no trabalho “Toda criança é capaz de aprender" ou ainda, "Piaget está interessado em comprovar experimentalmente suas especulações filosóficas sobre o nascimento e desenvolvimento das formas ou estruturas da inteligência; e em explicar 
como estas derivam daquelas, cumprindo uma única e mesma função adaptativa" (SZTERLING, 2000:25) no trabalho "Diálogo entre a psicanálise e a psicopedagogia: sobre a (im)possibilidade de aprender".

Partindo-se do princípio que as palavras adaptação e emancipação podem não ser explicitadas, elaboramos as tabelas 20a, 20b e 20c para ilustrar se o autor de cada trabalho analisado considera a Psicopedagogia como uma área mais voltada para uma educação adaptativa ou emancipatória, independentemente dos dois termos aparecerem ou não em seus trabalhos. O critério para definir que posição o trabalho defende foi o de observar inicialmente se as questões relacionadas com a educação voltada para adaptação e emancipação foram contempladas. No entanto, para serem contempladas não bastou serem citadas, mas sim apresentadas com um certo grau de coerência durante todo o trabalho. Para uma tese ou dissertação serem consideradas como defendendo uma posição de educação emancipatória, elas devem considerar o problema educacional não apenas como problema do aluno ou do professor ou da instituição seja escolar, familiar ou outra. Mas devem fazer uma crítica social apontando que devido à maneira como a sociedade está estruturada, a educação apresenta problemas que só poderão ser sanados de fato, mediante uma reorganização social. Ou seja, a sociedade administrada não admite uma educação emancipatória, não é possível que ambas convivam simultaneamente.

TABELA 20a - Freqüência e proporção de dissertações e teses da ANPED que apresentam a psicopedagogia voltada para uma educação adaptativa ou emancipatória

frequência

proporção

Educação adaptativa

12

0,8

Educação emancipatória

03

0,2

Total

15

01 
Como podemos observar, a maior parte dos trabalhos $(0,8)$ dizem ser a Psicopedagogia uma área mais voltada para questões adaptativas relacionadas à educação. Vale lembrar que aqui a educação adaptativa é entendida como uma educação regressiva, que entende a adaptação para fins irracionais da sociedade. Este fato é importante ser explicitado para não ficar parecendo que há uma dicotomia, em outras palavras, para não parecer que a educação ou é emancipatória ou adaptativa. $\mathrm{Na}$ verdade a educação emancipatória depende da adaptação como já explicado no Capítulo 1, lembrando que se entende por adaptação conhecimentos adquiridos pela sociedade ao longo dos tempos. No entanto, este conhecimento deve ser refletido e não apenas entendido como mais uma informação memorizada ou sem conexão com a sociedade atual.

O que foi observado em todos os trabalhos que apontam e defendem uma Psicopedagogia voltada para uma educação adaptativa foi a tendência de defenderem em sua parte teórica uma educação voltada para a autonomia enquanto crescimento e desenvolvimento do indivíduo. No entanto, entendem esse desenvolvimento como um vir a ser já determinado a priori bastando serem estimulados, da mesma maneira que as plantas crescem e se desenvolvem quando são regadas, e já sabemos qual será o resultado desse crescimento. É uma visão determinista e "biologizada" da educação. Não foi à toa que o referencial teórico mais utilizado nos trabalhos analisados foi o piagetiano. O sociointeracionismo entende a educação como resultado da interação entre o indivíduo e o meio, ou seja, um meio biológico enquanto número de estímulos suficientes para desenvolver as qualidades do indivíduo que é igual aos outros em possibilidades para que se torne alguém "educado".Temos segundo esse referencial a possibilidade de controle e previsibilidade do resultado. São trabalhos que reproduzem o esquema social em que 
vivemos, no qual os estímulos já possuem a priori a resposta esperada, em que tudo é controlado de maneira a ter resultados eficientes. Os resultados, os fins são mais importantes do que o processo. Dessa forma, não há possibilidade de autonomia e, portanto, de emancipação desses indivíduos, já que eles já são determinados mesmo antes de serem "educados" dando margem a uma educação heteronômica. Se não se tornam como o modelo de indivíduo "normal", precisam automaticamente de um tratamento para desenvolverem as habilidades consideradas normais e indispensáveis para que um ser humano seja considerado ser humano. Ou ainda, seguindo o esquema da teoria da carência cultural, altera-se a metodologia educativa para atender e adaptar-se aos alunos diferentes estereotipando-os, logo não possibilitando emancipação. Por isso, umas das alternativas é a criação de propostas metodológicas de interação entre o professor e o aluno, ou entre o aluno e o psicopedagogo de maneira que o aluno venha a se inserir no contexto escolar e de uma maneira mais ampla, no contexto social. Não foi à toa que dentre os objetivos das dissertações e teses predominaram sobre os demais a criação de propostas psicopedagógicas para alunos, escolas e demais instituições com a intenção de adaptar o aluno ao contexto escolar e de aprendizagem:

\footnotetext{
"Parece uma verdade elementar que a pedagogia há de repousar sobre o conhecimento da criança, do mesmo modo que a horticultura repousa sobre o conhecimento das plantas. E sem erro, é algo ignorado pela maioria dos pedagogos e por quase todas as autoridades escolares." (CLAPARÉDE apud ZILIO, 1993:10).
}

A autonomia também acaba em alguns casos sendo defendida enquanto teoria, mas no decorrer do trabalho o caminho vai em outra direção. Na tese "Psicopedagogia Institucional: a trajetória de seus atores-autores" é possível observar este aspecto. $\mathrm{Na}$ página 21 temos as seguintes afirmações: 
"Cada escola desenvolverá uma filosofia, um fazer, uma ação específica... sem lugar para a reprodução... só a transformação, a criação terá espaço... Haverá sempre uma parte comum a todas as escolas (princípios gerais que regem a educação), o que possibilitará o êxito mediante a articulação com sua filosofia. Tal filosofia propõe transformar o já pensado, o autorizar a todos a pensar, compromissando-os com as idéias ações... " (NOFFS, 1996:21).

\footnotetext{
"Garantir a autonomia de pensamento através de um espaço onde as significações dos elementos do grupo possa ocorrer. Uma escuta, um olhar que se torne psicopedagógico no sentido de outorgar, consentir que as diferenças se apresentem. A autonomia (independente, livre, que se governa por leis próprias, que professa as próprias opiniões) pode levar a autonomia (mutilação espontânea que certos artrópodes, aranha, caranguejo praticam em si próprios, geralmente para escapar ao inimigo que os domina), na busca da heteronomia (subordinação ou sujeição à vontade eo outrem ou a uma lei exterior) grupal. Esta heteronomia deve ser vista não como submissão mas como parceria." (NOFFS, 1996)
}

Essas frases poderiam dar a impressão que o trabalho caminharia em um sentido emancipatório, mas o problema é que a autora entende que todas essas conquistas são possíveis sem um questionamento ou alteração na estrutura social, pelo menos em nenhum momento isso é citado ou comentado. A seguir no trabalho, incoerentemente ela comenta que a autonomia deve ser evitada e deve ser tarefa do psicopedagogo ajudar nessa evitação: "Evitar a autonomia é tarefa grupal a ser constantemente estimulada pelo psicopedagogo” (NOFFS, 1996:73). Enfim, em sua definição de Psicopedagogia Institucional fica clara como a tendência que ela mantém é de entender a Psicopedagogia como área que procura resolver os problemas de aprendizagem a partir de situações pontuais, individuais (no caso a instituição) como não propiciadora de aprendizagem. Ela entende Psicopedagogia Institucional como a transformação da própria Pedagogia, devendo estudar as modalidades de ensino-aprendizagem desencadeadas e ou possibilitadas pela instituição escola, visando à prevenção e enfrentamento de conflitos 
(NOFFS, 1996). Tudo se resume em propiciar situações que possibilitem a aprendizagem.

Não se fala como deve ser esta aprendizagem.

A Psicopedagogia traz uma inovação, aumenta a gama de opções para poder trabalhar com esses alunos que não são considerados normais, ou como muitas vezes é dito nesses trabalhos de uma maneira mais amena, alunos que são normais mas apresentam problemas ou distúrbios relacionados à aprendizagem, ou seja, só são anormais nesses aspectos, não deixando de normatizar portanto. A Psicopedagogia também aparece para diagnosticar a origem desses problemas, ou seja, se é orgânico, afetivo, pedagógico, social etc. "Bastava só um empenho maior do professor do ensino regular e o distúrbio de aprendizagem se resolveria. Era mais falha do professor do que do aluno" (MATIODA, 1998:13). Neste caso bastaria um trabalho com estes professores por parte do psicopedagogo para o problema educacional se resolver.

Este tipo de visão em que o problema é o meio seja ele o professor, a escola ou outro, também aparece no trabalho "Psicopedagogia Inter-Ativa: ação psicopedagógica institucional baseada em uma convergência teórica": Para Lapierre, referencial utilizado pela autora, a criança possui as potencialidades positivas para o aprendizado bastando descobri-las e desenvolvê-las para o aluno aprender. O professor poderia ser uma dessas pessoas a descobrir tais potencialidades ou então o psicopedagogo. Ainda segundo o autor, devemos nos ater ao positivo e não ao negativo da criança:

\footnotetext{
"Na criança existem muitas potencialidades positivas e devemos procurar descobri-las e desenvolvê-las para que não seja sempre fixado o que ela não sabe fazer. A vivência psicomotora não é isolada, cortada do pedagógico, é 'preciso oferecer à criança um meio pedagógico coerente, sem o que arriscamos acentuar sua inadaptação a uma escola que é, ela mesma inadaptada'”(MAMAN, 1997:45-46).
} 
Ou seja, toda a solução está no meio, bastando encontrar um meio adequado que as potencialidades do aluno desenvolvem-se como plantas quando regadas. Os objetivos desse trabalho foram realizados em quatro níveis pragmáticos segundo a autora: preventivo, curativo, assistencial e teórico, mostrando novamente a tendência da "medicalização" na área da educação, com tentativas de prevenir e curar problemas de aprendizagem como epidemias.

O fracasso escolar é causado segundo a autora por problemas de origem familiar, emocional e cultural do aluno:

\footnotetext{
“A educação hoje é direito de todos instaurando o fracasso escolar pois nem todos conseguem superar o programa de ensino e adequar-se às normas de conduta exigidas como padrões disciplinares. Deveriam ser levados em conta aspectos fundamentais para o bom desempenho escolar como os culturais, psicológicos e a influência familiar" (MAMAN, 1997:03).
}

Especifica as causas das dificuldades de aprendizagem como sendo de natureza metodológica, estrutural, cultural, afetiva, social entre outras (MAMAN, 1997). Estes itens são apenas citados e não explicados ou definidos. Ela entende que em cada ocasião o problema de aprendizado pode ser causado por um fator diferente e não por uma sociedade que não possibilita a autonomia dos indivíduos, isso nem chega a ser questionado. Maman entende que os problemas de aprendizagem têm sua origem principalmente na má formação dos professores e que esta defasagem é específica desses professores dessa instituição em particular, e, portanto, a deficiência deveria ser corrigida pela instituição de trabalho do professor. Ela não entende que a má formação de professores é um problema geral e mais do que isso, não basta qualquer formação, mas uma formação que dê condições para o professor de fato poder entender o que é uma educação emancipatória, de 
maneira a poder atuar como modelo para seus alunos. A outra solução que apresenta para resolver os problemas de aprendizagem de uma maneira geral é reunir o que ela denomina de "tríade para o sucesso": profissional da Psicopedagogia, professor (escola) e família. Com estes três elementos reunidos o trabalho psicopedagógico terá êxito e por conseguinte, a Educação também terá. A autora procura o tempo todo justificar o facasso escolar apontando como causas setores particularizados sendo que o aspecto social fica em segundo plano, como mais uma das várias possibilidades particulares. Ela entende por aspectos sociais os seguintes:

\footnotetext{
"Relacionam-se às questões familiares e ao meio que cerca $o$ sujeito, estando aqui incluídos a formação familiar, as condições econômicas, o acervo de sua cultura, os objetivos vistos pela família com relação à escolarização, as expectativas familiares com relação à aprendizagem do sujeito" (MAMAN,1997:19).
}

Ela enfatiza que a história tem uma importância fundamental no entendimento dos problemas de aprendizagem, mas ela se refere a história específica do aluno em particular e não da História da sociedade. Essa História não é mencionada e nem colocada como tendo importância. O trabalho que a autora desenvolve com os alunos da escola é mais no sentido da prática do que no da reflexão mantendo o padrão dos trabalhos psicopedagógicos. A maior parte das atividades propostas consiste em construir alguma coisa concreta: loja, posto de gasolina, fazenda, prédio etc. Ou então jogos competitivos com regras como torneio de dominó, memória etc. A atividade mais reflexiva que ela denomina de "livre-expressão" envolve o desenvolvimento de desenhos e histórias que, no entanto, não são analisados e trabalhados em maior profundidade. Ou seja, o trabalho que ela propõe se assemelha mais a um curso de artesanato, não desmerecendo essa prática, do que um trabalho formativo no sentido de fazer uma reflexão com as crianças sobre 
aspectos do mundo questionando-os ou de mostrar as enganações que estamos em contato todos os dias. Pelo contrário, ela acaba em muitas vezes colaborando para este tipo de pensamento, quando por exemplo é criado o "Prédio Feliz". A idéia de felicidade e harmonia que a nossa sociedade quer que acreditemos é enfatizada por ela quando não questiona o motivo do prédio ser feliz, ou se é possível ser feliz nas condições que a nossa atual sociedade se encontra atualmente com essa violência exagerada. Mesmo nas fotos dos alunos que ela não permite que vejamos suas fisionomias, ela desenha carinhas alegres por cima das deles, passando a idéia de que todos estão alegres e satisfeitos com o resultado do trabalho psicopedagógico. Ela fala da importância do trabalho cooperativo: será que este é possível? Ela prepara estes alunos para este tipo de trabalho?

Parte do princípio que para haver aprendizagem basta um ambiente harmonioso, novamente se remetendo a teorias com bases "biologizantes".

Em relação ao aspecto social relacionado aos problemas da educação, todos esses autores citam essa possibilidade. Mas fica como uma dentre as possíveis e várias causas dos problemas educacionais e não como a principal. Para os autores, o aluno deve ser visto de "maneira global", levando em conta, portanto, aspectos orgânicos, afetivos, institucionais e sociais. Como foi dito, o social é apenas citado como um dos possíveis itens e nem sempre é definido, ficando subentendido o que quer dizer a palavra social. Na maior parte dos trabalhos o termo social é entendido como meio, que pode ser o familiar, por exemplo. Apenas em poucos trabalhos o termo foi definido. Este é um exemplo que ilustra bem a definição entendida para este termo "estão ligados às perspectivas da sociedade em que estão inseridos a família e escola” (MATIODA, 1998:13). 
Em um dos trabalhos, em que há várias entrevistas com diversos autores da área, apenas uma das autoras entrevistadas comenta um pouco sobre a questão social e política na educação e da importância do desenvolvimento de um pensamento autônomo e que o psicopedagogo poderia contribuir com este item. Mas o que mais chama a atenção, é que quando a autora da dissertação faz sua análise sobre a entrevista dos autores, omite esse dado.

Uma outra postura que apareceu nos trabalhos foi a Psicopedagogia como prática clinica. Nesses trabalhos, a maneira de sanar os problemas de aprendizagem utilizada pelos autores foi a escuta psicanalítica e autoconhecimento. Alguns autores, como Lajonquiere (1992), fazem uma análise mais cuidadosa e profunda dessas questões, mas apontam a Psicanálise como solução para os problemas do fracasso escolar, embora sendo importante ressaltar que não temos controle dos resultados obtidos pela Psicanálise, uma vez que o inconsciente não é passível de controle e previsão. O problema geral dos trabalhos que defendem a Psicanálise como solução para os problemas de aprendizagem é fazer uma apropriação inadequada da teoria, entendendo a clínica psicanalítica de maneira medicalizada, aonde os pacientes dirigem-se a ela para terem um tratamento eficaz que sane a "epidemia" da aprendizagem, termo muito utilizado nos trabalhos e por autores de referência na área. E ainda, entendendo o Inconsciente psicanalítico como uma instância individual que reflete os problemas pessoais daquele paciente, podendo no máximo se estender à sua família ou escola ou meio.

Como podemos observar na tabela, apenas três trabalhos trouxeram a educação para emancipação não explicitada com este nome, mas enquanto idéia. Em um deles, “A invenção da adolescência no discurso psicopedagógico" não houve uma defesa de que a 
Psicopedagogia faz uso da questão social para análise de problemas na educação. Mas a contribuição que este trabalho teve em relação a um pensamento emancipatório foi o de criticar o discurso psicopedagógico em relação ao termo adolescência apontando sua fragilidade. Esse trabalho teve a preocupação em mobilizar uma conscientização sobre alguns conceitos pré-estabelecidos como únicos e que a identidade desses conceitos se dão em um processo histórico, em um contexto com amplitude. No caso desse trabalho, o termo adolescência no discurso psicopedagógico é apontado como se referindo a um "sujeito estéril, posto que monolítico e a-histórico, isto é, um sujeito portador de uma essência já conhecida, obstruindo assim a possibilidade de se chegar a novas conclusões" (CÉSAR, 1998:2). Portanto, essa autora é contrária a posições que apresentam dados apresentados de antemão como determinados, imutáveis e com tendência à reificação. “...discurso das ciências médicas e psicopedagógicas, que reproduzem um modelo normatizador e totalizante quando elaboram seus saberes sobre essa figura" (CÉSAR, 1998:5). Este trabalho, portanto, realiza uma crítica à cultura e aponta para a importância da análise dos discursos para poderem ser desconstruídos e terem a possibilidade, portanto, de transformação.

O outro trabalho considerado como abordando a psicopedagogia de acordo com a educação emancipatória foi “A atuação do profissional em Psicopedagogia e a formação do psicopedagogo em São Paulo no período de 1980 a 1990”, aonde foi realizada uma reflexão teórica que caminhou em um sentido crítico. A autora fez um estudo da Psicopedagogia em São Paulo enquanto área de conhecimento e profissão de forma crítica como já dito anteriormente, mostrando que da maneira que a Psicopedagogia está estruturada e é pretendida está servindo a interesses coorporativistas, ou seja, apontou seus aspectos regressivos e que não contribuem para uma educação emancipatória. Uma das 
suas conclusões expressa bem a dinâmica do trabalho: A Psicopedagogia não é algo em si, mas pertence a uma dinâmica social específica que a produz (NASCIMENTO, 1993).

E o terceiro trabalho que caminhou no sentido da educação para emancipação foi “Epistemologia genética e prática psicopedagógica na escola: difusão da teoria e os expurgos da razão" que procurou buscar e analisar a difusão de idéias de Piaget sobre aprendizagem nos documentos e relatos sobre a prática psicopedagógica na escola desenvolvida na Secretaria Municipal da Educação de Porto Alegre em 1989-1993. Nesse trabalho foi escolhido analisar o referencial piagetiano porque foi o adotado pela Secretaria. Dessa análise a autora conclui que embora a Secretaria defenda um referencial, acaba por utilizar um ecletismo que aponta para incoerências e contradições nos pressupostos de seu discurso. Embora não fale diretamente sobre fins emancipatórios para a Psicopedagogia ou para a educação, consideramos este trabalho como voltado para a emancipação pois possui objetivos críticos e em alguns momentos ele realiza crítica da educação relacionada à sociedade em que vivemos.

TABELA 20b - Frequiência e proporção de dissertações e teses do programa de pós-graduação das faculdades de Psicologia que apresentam a psicopedagogia voltada para uma educação adaptativa ou emancipatória

\begin{tabular}{ccc}
\hline & frequência & proporção \\
Educação adaptativa & 05 & 0,8 \\
Educação emancipatória & 01 & 0,2 \\
Total & $\mathbf{0 6}$ & $\mathbf{0 1}$ \\
\hline
\end{tabular}

Pela tabela 20b podemos concluir que dos seis trabalhos analisados apenas um visa uma Psicopedagogia voltada para uma educação emancipatória. Os demais priorizam uma educação adaptativa. 
Em um dos trabalhos, as palavras adaptação e emancipação não chegam a ser utilizadas e não há uma preocupação com esses termos no decorrer do trabalho. No entanto é possível inferir qual o sentido dado ao trabalho que é predominantemente o de "adaptar" uma vez que a tese apresenta como referencial teórico a Epistemologia Genética. Este referencial adota a adaptação como essencial para a sobrevivência do ser humano. Este termo é entendido da mesma maneira que as teorias biológicas entendem esta função: os mais fortes resistindo e os mais fracos sendo eliminados. Daí já é possível subentender que este tipo de trabalho defende uma educação predominantemente adaptativa e "biologizante".

O único trabalho voltado para uma educação emancipatória, "Um estudo psicanalítico sobre a produção do conhecimento na criança psicótica", analisa criticamente ao se referir aos parâmetros de ação utilizados na psicose infantil quando esta não é analisada junto ao que ele nomeia de discurso do conhecimento ou quando é analisada nas intersecções com o discurso do conhecimento. "As práticas e intervenções que aqui são engendradas tomam, como parâmetros de ação, as idéias de inadaptação e inadequação social, o que envolve a necessidade de afastamento e exclusão..."(LIMA, 1998:139). Faz uma análise do tema de maneira crítica, procurando discutir de "qual lugar o homem pensa e discute o que nomeia e legitima como produção do conhecimento" (LIMA, 1998:07-08). Embora não utilize diretamente a teoria crítica em sua análise, utiliza idéias semelhantes a Adorno em relação ao conhecimento e sua evolução ao longo dos tempos. "Se antes as divindades e a ordem do divino a ocupavam, o Mundo das Idéias outorgou-se as suas prerrogativas, sem questionar ou interpelar os seus alicerces e fundamentos" (LIMA, 1998:09). 
As demais dissertações e teses seguiram o esquema de aplicarem uma teoria seja ela a psicanálise, epistemologia genética, psicodrama e chegaram a conclusões a partir da aplicação direta dessas teorias sem um prévio questionamento se elas incluem uma análise crítica da sociedade de maneira a não reproduzirem a educação já instalada até então. Por exemplo, em "Oficina criativa e psicopedagogia", a autora utiliza frases como:

\footnotetext{
"Considero muito importante que o educador conheça muito bem a criança com quem trabalha, para que escolha situações em que possa levá-la a desenvolver uma autonomia de sua gestão mental”. (ALLESSANDRINI, 1995:33). "A proposta da Psicopedagogia é trabalhar basicamente com as relações afetivas ocorridas entre o indivíduo e o conteúdo de aprendizagem, garantindo atitudes tais como: espontaneidade ao lidar com o pensamento, a perseverança no trabalho, a autonomia e autoconfiança, enquanto sujeito criativo $e$ transformador." (ALLESANDRINI, 1995:25). “A primeira imagem estava carregada de significado simbólico, mas ainda não era possível realçar a figura, dentro do pano de fundo que é o ser "a si mesmo"(ALLESSANDRINI, 1995:38).
}

Em nenhuma dessas frases e em várias outras foi questionado por exemplo se é possível na sociedade em que vivemos um indivíduo autônomo e autoconfiante, criativo e transformador. Ou ainda, o indivíduo transformador visa transformar o que? Se for a ele próprio, de qual maneira? De maneira a adaptar-se ao status quo? Ou se for para transformar a sociedade: transformá-la em qual sentido e visando qual direção? Ou ainda, é possível ser "si mesmo" nessa sociedade? E ainda mais uma vez vemos a aprendizagem sendo entendida como critério de saúde ou doença, retomando novamente a tendência à medicalização na Psicopedagogia e demais áreas do conhecimento relacionadas a Educação. “A Psicopedagogia propõe uma compreensão dessa questão, e minha busca tem-se direcionado diante da necessidade de encontrar novas formas de trabalhar o problema, para que aquele que o vive possa reestruturar sua forma de ser, fazer e aprender, em uma dinâmica saudável do ser aprendiz” (ALLESSANDRINI, 1995:51). 
O mesmo ocorre com as demais dissertações e teses como em "Psicodrama e construtivismo como uma psicopedagogia: estudos com crianças e adolescentes" que utiliza frases como: "Nesse sentido, os elos de autoridade e de respeito unilateral, característico das relações de autonomia, em que a cooperação pode ser identificada pelos elos de igualdade e respeito mútuo, produtos da reciprocidade" (WECHSLER,1994:22) Não é questionado em nenhum momento se é possível de fato na sociedade em que vivemos sermos iguais em direitos e não em normas. Outra idéia constante nesse tipo de pensamento é a de progresso: atingir uma meta é uma questão de construção e de etapas a serem seguidas para se atingir um alvo. Estas etapas se apresentam linearmente, ou seja, é uma questão de tempo e de superação da fase anterior que é possível se atingir o progresso: "Se concebemos a socialização, caminho para tornar a criança apta a cooperação (operar junto com), como um dos aspectos do progresso rumo à descentração..." (WECHSLER,1994:25). Socialização aqui mais uma vez entendida como meio estimulante, podendo ser a família que forneça condições estímulos - para se atingir tal meta. E finalizando, a técnica, a prática é vista como resolução para todos os problemas educacionais, mais uma vez distanciando-se de uma educação emancipatória. "inversão de papel como técnica de ensino e aprendizagem" (WECHSLER,1994:13). "Parece que o pressuposto para o ensino e aprendizagem é ensinar fazendo”. (WECHSLER,1994:14). Não quero dizer com estas observações que a técnica e a prática não sejam importantes para a educação, mas a utilização delas sem uma reflexão, ou seja cindidas é entendido como problemático sim.

Uma dissertação, "Leitura e retardamento mental: estudos com o "lendo e escrevendo", além de fazer aplicação direta da teoria, utilizou-se de testes de prontidão para alfabetização e viso-motores de maneira a classificar as crianças consideradas 
retardadas mentais em relação a sua capacidade de leitura e escrita. Em nenhum momento foram questionados tais instrumentos de medida. Eles funcionaram como critério de avaliação dessas crianças e para uma posterior adaptação de técnicas para atender essas crianças consideradas diferentes das demais por suas condições econômicas desfavoráveis. É mais uma vez o aparecimento da teoria da carência cultural.

TABELA 20c - Frequiência e proporção de dissertações e teses do programa de pós-graduação das faculdades de Educação que apresentam a psicopedagogia voltada para uma educação adaptativa ou emancipatória

\begin{tabular}{ccc}
\hline & frequência & proporção \\
Educação adaptativa & 03 & 1,0 \\
Educação emancipatória & 00 & 00 \\
Total & $\mathbf{0 3}$ & $\mathbf{0 1}$ \\
\hline
\end{tabular}

Em todos os trabalhos vemos uma Psicopedagogia voltada para a adaptação. Uma delas utilizando a aplicação direta de conceitos da teoria piagetiana e na outra, a defesa da psicanálise como técnica psicopedagógica. Na terceira delas, voltada mais para a Lingüística há uma ênfase na importância do prazer na aprendizagem. Cita diversas vezes palavras como alegria, prazer, felicidade, etc. Fala rapidamente sobre a importância da crítica na educação, mas o ponto chave da sua defesa em relação ao aprendizado é o prazer, que deve ser uma obrigação da escola proporcionar aos alunos. Essa defesa da aprendizagem prazerosa é relacionada com a aprendizagem a partir do afetivo, considerando não só o cognitivo, mas o emocional da mesma forma que, por exemplo, na obra "Inteligência emocional" (GOLEMAN, 1995). Enfim, faz uma cisão entre aprendizagem cognitiva e emocional, fazendo uma defesa da inteligência emocional e relacionada ao prazer na aprendizagem. Vale lembrar mais uma vez que entender que a criança deva aprender só a partir de situações prazerosas é menosprezar a capacidade da 
criança em aprender em situações cotidianas, onde o erro e a frustração não podem ser abolidos.

\section{Análise das dissertações e teses}

A seguir, nas tabelas de 14 a 20, serão apresentados os dados colhidos na leitura das dissertações e teses selecionadas para este trabalho.

O total dos trabalhos lidos é de 24 , sendo 15 trabalhos da $A N P E D$, seis dos programas de Pós-graduação de faculdades de Psicologia e três dos programas de Pósgraduação de faculdades de Educação. As dissertações e teses que se repetem na ANPED e programa de Pós-graduação em faculdades de Educação foram contabilizados apenas uma vez na tabela referente aos trabalhos da $A N P E D$. Aliás, esta divisão de quantidade de trabalhos entre ANPED e programas de Pós-graduação em faculdades de Psicologia e Educação já foram contabilizados levando em consideração tal critério de repetição.

Nas tabelas podem aparecer números superiores aos citados acima, uma vez que o item da tabela denominado "total" é relativo ao item analisado e não ao número de obras analisadas. Por exemplo, na tabela 14a, na qual estão caracterizadas as concepções de Psicopedagogia existentes nas 15 dissertações e teses da $A N P E D$, aconteceu de em um mesmo trabalho ter aparecido mais de uma concepção, que foi assim, computada nessa tabela, ultrapassando, portanto no total, o número de 15 e totalizando 28 . O número 28 corresponde assim, ao total de concepções encontradas nas 15 dissertações e teses. 
As respectivas tabelas tratam dos seguintes assuntos analisados nas dissertações e teses: concepções de Psicopedagogia apresentadas em cada uma delas; objetivos apresentados; tipo de pesquisa, ou seja, se teórica ou empírica; referenciais teóricos adotados e conclusões obtidas. Finalmente, as duas últimas tabelas tratam dos temas "adaptação" e "emancipação", sendo que na primeira delas são analisadas as dissertações e teses que tiveram a preocupação em citar ou não os dois termos e na segunda tabela são verificados se os trabalhos tomaram uma direção voltada para uma educação emancipatória.

A seqüência das tabelas foi organizada da seguinte maneira: para cada assunto elas são apresentadas em três subdivisões sendo a primeira delas dedicada aos trabalhos da ANPED; a segunda delas aos trabalhos dos programas de Pós-graduação em faculdades de Psicologia, seguido da terceira tabela com os trabalhos dos programas de Pós-graduação das faculdades de Educação.

$\mathrm{Na}$ tabela 14a temos a freqüência e proporção das concepções entendidas para Psicopedagogia nas dissertações e teses analisadas da ANPED. 
TABELA 14a - Freqüência e proporção de concepções entendidas para Psicopedagogia nas dissertações e teses da $A N P E D$

\section{Concepções}

Prática clínica, estratégia ou área que estuda processos e/ou problemas e/ou modalidades de aprendizagem

Termo que une Psicologia e Pedagogia ou ciência multi e interdisciplinar

Área da aprendizagem com função curativa e/ou preventiva

Ciência autônoma

Não adota concepção

Área que cria novas propostas metodológicas relacionadas à educação

Inter-relações entre elementos cognitivos, afetivos e sociais da aprendizagem

Clínica ortopédica que alimenta o discurso hegemônico da Pedagogia

Total

\section{frequência proporção}

$11 \quad 0,4$

$05 \quad 0,2$

$05 \quad 0,2$

$02 \quad 0,1$

$02 \quad 0,1$

$01 \quad 0,0$

$01 \quad 0,0$

$01 \quad 0,0$

$28 \quad 01$

Segundo os dados da tabela 14a, observamos que dentre as concepções de Psicopedagogia, as mais freqüentes foram aquelas que apareceram em mais da metade das dissertações e teses e em 0,4 das categorias de resposta e que disseram ser a Psicopedagogia uma prática clínica, estratégia ou área que estuda processos elou problemas de aprendizagem elou modalidades de aprendizagem; em seguida temos com 0,2 das aparições, ou seja, em cinco trabalhos a Psicopedagogia como termo que une Psicologia e Pedagogia ou ciência multi e interdisciplinar e área da aprendizagem com função curativa elou preventiva. Ainda tivemos duas aparições de trabalhos que entendem a Psicopedagogia como uma ciência autônoma. E com apenas uma aparição temos a Psicopedagogia entendida como área que cria novas propostas metodológicas relacionadas à educação; inter-relações entre elementos cognitivos, afetivos e sociais da aprendizagem e clínica ortopédica que alimenta o discurso hegemônico da Pedagogia. É importante notar que apenas neste último trabalho, houve uma preocupação em apresentar 
uma concepção crítica da Psicopedagogia. Há dois trabalhos que não apresentam qual concepção adotam o que causa uma estranheza, pois é de extrema importância mostrar de que lugar estamos falando sobre um determinado assunto. Depois vemos que eles não adotam concepções pois justamente esta é a preocupação deles: analisar as concepções da Psicopedagogia embora isso não exclua o fato deles adotarem a sua própria concepção.

De uma maneira geral, a Psicopedagogia é considerada uma estratégia, área ou prática destinada a entender, prevenir e ajudar pessoas com problemas de aprendizagem ou ainda entender, prevenir e ajudar nos problemas de aprendizagem. $\mathrm{O}$ foco da Psicopedagogia é duplo: alguns trabalhos enfocam mais o ser humano que deve ser entendido e "trabalhado" para resolver seus problemas de aprendizagem ou evitar um futuro problema relacionado com aprendizagem; outros trabalhos enfocam, em sua definição de Psicopedagogia, o processo de aprendizagem em si considerando suas dificuldades e problemas. O que chama a atenção é que embora as definições sejam diversificadas, os autores utilizam ambos tipos de concepções em seus trabalhos.

Além disso, a aprendizagem é vista como um problema a ser solucionado ou prevenido, lembrando muito uma visão médica, que procura prevenir ou solucionar doenças ou síndromes. Como já vimos no Capítulo 2, a Psicopedagogia sofreu e sofre influência da Medicina e isso se reflete nos trabalhos. Isso é ainda mais reforçado na definição que diz que a Psicopedagogia é uma prática clínica que cuida dos problemas de aprendizagem. Neste caso, a Psicopedagogia pode ser entendida como uma prática de consultório que enxerga o aluno como um paciente a ser tratado, o problema é pontual, localiza-se no aluno ou instituições como sua família ou sua escola. Assim, se ele for encaminhado para um outro tipo de escola o problema pode resolver-se automaticamente, 
revelando que o problema de aprendizagem é uma simples questão de adaptação a certo tipo de ambiente educacional. O problema portanto é visto pontualmente.

Outra tentativa da Psicopedagogia é unir Pedagogia e Psicologia e tentar "cobrir" faltas que ambas as áreas possuem em relação a questões relacionadas com a aprendizagem. Essa alternativa também foi uma das que mais aparece. Em algumas dissertações foi possível observar uma preocupação da Psicopedagogia em suprir faltas dizendo que tal área de conhecimento engloba Sociologia, Medicina, Linguística etc. Ou seja segundo as concepções de Psicopedagogia que apareceram nessas dissertações e teses esta área de conhecimento ou estratégia ou prática clínica vem para resolver problemas que outras áreas do conhecimento não conseguiram sozinhas e, para isso, uniu diversas áreas de conhecimento para conseguir resolver o que outras áreas não conseguiram em relação às questões relacionadas à aprendizagem. Fica subentendido que o problema da aprendizagem pode ser resolvido pela quantidade, pela soma de áreas do conhecimento, seja ela a Medicina, a Psicologia, a Lingüística etc. Como até então ainda não foi possível resolver os problemas de aprendizagem, entende-se que apenas unindo diversas ciências este fim será alcançado. Assim, optam pela quantidade de técnicas e conhecimento de maneira a tentar suprir as falhas na Educação ocorridas até então.

Nessas concepções não fica bem especificado que tipo de aprendizagem que a Psicopedagogia está preocupada, mas pelo contexto dos trabalhos é possível perceber que o foco está principalmente nos problemas de aprendizagem escolares, no conteúdo que as escolas passam aos alunos e esses não conseguem aprender. Ainda que citem autores preocupados com questões relacionadas ao desenvolvimento do pensamento, ainda assim preferem dar ênfase a uma educação conteudística, mais preocupada em informar do que 
formar, Educação que na era da informação é a mais esperada, é aquele tipo de educação, pseudoformação.

Cabe ainda a Psicopedagogia realizar propostas metodológicas que propiciem aos alunos aprendizagem dos conteúdos escolares. A Psicopedagogia ao analisar ou fazer propostas para as questões relacionadas à aprendizagem procura levar em consideração os aspectos orgânicos, afetivos e socioculturais. No entanto, embora a maior parte das dissertações e teses citem estes aspectos, no corpo do trabalho, os aspectos sociais na maior parte das vezes não são levados em consideração, havendo uma maior ênfase nos orgânicos e principalmente nos emocionais. Desses trabalhos, em apenas um ("A invenção da adolescência no discurso psicopedagógico") o aspecto social foi considerado, discutido e contemplado durante a análise.

É importante lembrar que em uma das dissertações, "Psicopedagogia: um perfil profissional em conflito", a autora chama a atenção para a insuficiência de definições para a Psicopedagogia. No entanto foi possível observar várias definições ao longo dos trabalhos e por parte de autores da área, portanto não sendo verdadeira essa afirmação. $\mathrm{O}$ que parece ocorrer é uma falta de unidade entre elas além de uma maior diferenciação dessas definições quando relacionadas com a Pedagogia, Psicologia, Psicologia da Educação, Psicologia Escolar e Psicologia da Aprendizagem, o que parece ser difícil levando em consideração que a Psicopedagogia se proponha a unir tantas áreas de conhecimento simultaneamente. Mas aponta, logo em seguida, que há a definição da Associação Brasileira de Psicopedagogia (Abpp) “A psicopedagogia é a área que estuda e lida com os processos de aprendizagem e suas dificuldades (1990)". 
A autora do trabalho "A atuação do profissional em Psicopedagogia e a formação do psicopedagogo em São Paulo no período de 1980 a 1990" discute a falta de identidade da Psicopedagogia enquanto área que necessita de um único profissional: o psicopedagogo. Seus conteúdos são do interesse de diversos profissionais, parecendo a defesa do profissional psicopedagogo mais coorporativa do que uma necessidade real. A autora também considera a Psicopedagogia uma área muito ampla tornando-se "panacéia dos males da aprendizagem e do ensino, esvaziando seu sentido”. Entende que estamos diante de as "psicopedagogias", isoladas umas das outras, o que não confere identidade para a área. Sendo assim, sua concepção fica muitas vezes intuída.

De uma maneira geral, embora os autores das dissertações e teses apresentem definições para a Psicopedagogia, parece ainda não haver um consenso sobre a identidade da mesma. A maior parte dos autores alega que esta falta de identidade se deve pelo fato dessa área de conhecimento ser relativamente nova. Na verdade, esta falta de identidade estaria relacionada ao não cumprimento daquilo que ela se propõe, ou seja, cobrir as lacunas deixadas por duas áreas do conhecimento (Psicologia e Pedagogia) transcendendo seus limites. Ela acaba não realizando o que se propõe pelo menos até então.

\footnotetext{
"A Psicopedagogia se ocupa da aprendizagem humana, que adveio de uma demanda - o problema de aprendizagem, colocado num território pouco explorado, situado além dos limites da Psicologia e da própria Pedagogia... constituindo-se assim, numa prática. Como se preocupa com o problema de aprendizagem, deve ocupar-se inicialmente do processo de aprendizagem" (BOSSA, 2000:21).
}

Ou ainda, podemos ver uma ênfase dada à concepção de Psicopedagogia como "ciência da prática". Já que não encontra uma singularidade, a prática muitas vezes acaba sendo sua marca registrada, revelando como essa área do conhecimento está em "sintonia" com a sociedade administrada em que vivemos, onde a técnica, a eficiência, a prática 
(saber fazer) possuem uma importância extrema, deixando em segundo plano a reflexão por exemplo, a conscientização e todos outros aspectos que permitam uma possibilidade de suplantar este tipo de sociedade, caminhando no sentido de uma educação emancipatória. No trabalho "Psicopedagogia Institucional: a trajetória de seus atores-autores" essa concepção fica bem clara uma vez que é ressaltada no mesmo trabalho. Por exemplo, “...criou novas alternativas de ações, permitindo uma intervenção além da pedagogia, contribuindo com a ciência da prática. (NOFFS, 1996:10). É a defesa do "saber aplicar" e o "saber fazer" como uma inovação, como a solução para todos os problemas relacionados ao assunto.

$\mathrm{Na}$ tabela 14b temos a freqüência e proporção das concepções entendidas para Psicopedagogia nas dissertações e teses analisadas dos programas de Pós-graduação das faculdades de Psicologia.

TABELA 14b - Freqüência e proporção de concepções entendidas para Psicopedagogia nas dissertações e teses dos programas de pós-graduação das faculdades de Psicologia

\section{Concepções}

Prática clínica, estratégia ou área que estuda processos e/ou problemas e/ou modalidades de aprendizagem

Não diz

Termo que une Psicologia e Pedagogia ou ciência multi e interdisciplinar

\section{frequência proporção}

$04 \quad 0,6$

$02 \quad 0,3$

$01 \quad 0,1$

\section{Total}

07

01

Igualmente, nos trabalhos defendidos nos programas de Pós-graduação das faculdades de Psicologia a maior parte dos trabalhos, quatro de seis $(0,6$ das possibilidades de resposta) entendem a Psicopedagogia como prática clínica, estratégia ou área que estuda processos elou problemas de aprendizagem. 
Um fato que chama a atenção é que nos trabalhos defendidos nos programas de Pós-graduação das faculdades de Psicologia a maior parte dos trabalhos, quatro de seis, não explicitam sua concepção de Psicopedagogia. No entanto só apontamos dois deles como não dizendo a concepção que adotam porque em dois deles não são explicitadas e não é possível tentar deduzir ao longo dos mesmos trabalhos. Nos outros dois é possível tentar deduzir o que entendem por Psicopedagogia: de maneira adjetivada como aplicação da Psicologia à Pedagogia ou a intersecção de ambas e sua aplicação na clínica ou escola. Essa é uma postura muito comum, segundo Bossa (2000), utilizada no início da década de 80 aqui no Brasil. No entanto, essa tendência perdurou ao longo dessa década e na seguinte também, pelo menos no que consta nas faculdades de Psicologia da USP e PUC. Parece que por parte desses autores não há uma preocupação imediata em estudar a Psicopedagogia como uma área autônoma ou talvez não tenham consciência de sua existência ou pelo fato de não entenderem como sendo uma área independente das demais.

Na tabela 14c temos a freqüência e proporção das concepções entendidas para Psicopedagogia nas dissertações e teses analisadas dos programas de Pós-graduação das faculdades de Educação.

TABELA 14c - Freqüência e proporção de concepções entendidas para Psicopedagogia nas dissertações e teses dos programas de pós-graduação das faculdades de Educação

\section{Concepções}

Prática clínica, estratégia ou área que estuda processos e/ou problemas e/ou modalidades de aprendizagem

inter-relações entre elementos cognitivos, afetivos e sociais da aprendizagem

Não diz frequência

01

01

01

03 proporção

0,3 
Na tabela 14c observamos também repetições de concepções encontradas nos trabalhos defendidos na ANPED e nas faculdades de Psicologia (PUC-SP e USP-SP): Psicopedagogia como prática e que estuda problemas de aprendizagem pertencentes ao sujeito que não aprende e área que estuda a aprendizagem que é realizada pela inter-relação de elementos cognitivos, afetivos e sociais. Aqui mais uma vez chamando a atenção uma dissertação que não cita sua concepção de Psicopedagogia.

Fazendo uma análise cronológica das concepções adotadas nessas dissertações e teses, observamos que algumas tendências permaneceram ao longo desses anos como: Psicopedagogia entendida como prática que procura estudar e resolver problemas de aprendizagem levando em conta os aspectos orgânicos, cognitivos, afetivos e sociais. A década de 80 de uma maneira geral revelou esta tendência. Mas no final dessa década, em 1989, aparece pela primeira vez a preocupação em fazer uma análise das concepções da Psicopedagogia ao invés de adotá-las apenas da maneira aleatória.

Nos anos 90 notamos uma preocupação na primeira metade da década de se estudar as concepções da Psicopedagogia seguindo a tendência que começou a aparecer em 1989, ou ainda, é quando há uma percepção de que faltam concepções ou definições que dê unidade a esta área, havendo inclusive uma das dissertações que aponta para a falta de concepções e definição para a área. Concepções que entendem a Psicopedagogia como área que estuda ou resolve problemas de aprendizagem continuam a aparecer nos demais trabalhos.

Na segunda metade da década de 90 observamos uma preocupação crescente em diferenciar a Psicopedagogia das demais áreas do conhecimento, seja mostrando que ela 
engloba diversas áreas como Psicologia, Pedagogia, Fonoaudiologia etc, seja dizendo explicitamente que é uma ciência autônoma. Nessa fase, também aparece na maior parte das definições a Psicopedagogia como área que se encarrega da prevenção dos problemas de aprendizagem, o que acaba revelando que mesmo no final do século, ainda assim a Medicina tem um poder sobre as demais ciências, ou seja, o problema de aprendizagem ainda é entendido nesse contexto, tendo que ser prevenido pela Psicopedagogia da mesma forma que a Medicina faz com as doenças, mostrando que não houve um avanço no sentido de se entender problemas de aprendizagem a partir de um contexto crítico da sociedade. Vale lembrar que na maior parte dos trabalhos, eles fazem questão de criticar a abordagem orgânica dos problemas de aprendizagem e citar a importância dos fatores emocionais, cognitivos e sociais. Mas acabam por adotarem como concepção aquilo que eles mesmos criticam. Em apenas quatro trabalhos de 24, a crítica do discurso psicopedagógico se cumpriu.

$\mathrm{Na}$ tabela 15a são apontados os principais objetivos das dissertações e teses selecionadas para esta pesquisa.

TABELA 15a - Freqüência e proporção de dissertações e teses, segundo os objetivos traçados nas pesquisas da ANPED.

\section{Objetivos}

Elaborar proposta psicopedagógica

Conceituar e diagnosticar os problemas de aprendizagem de determinado(s) aluno(s)

Estruturar a Psicopedagogia como campo de conhecimento prático, docente e clínico; buscar uma fundamentação teórica para a Psicopedagogia

Analisar aspectos como a formação, perfil, objeto de trabalho do psicopedagogo, os meios, locais e relações de trabalho Identificar a situação existencial do idoso de classe média Buscar as idéias de Piaget sobre aprendizagem nos documentos e relatos sobre a prática psicopedagógica na escola relativa a uma

\section{frequência proporção}

$06 \quad 0,3$

$03 \quad 0,2$

$02 \quad 0,1$

$02 \quad 0,1$

$01 \quad 0,0$

$01 \quad 0,0$ 
determinada Secretaria da Educação

Verificar se atividades de "domínio espacial" produzem efeitos na

superação do egocentrismo infantil

Analisar discurso psicopedagógico

$01 \quad 0,0$

Opiniões de alunos sobre o curso de Psicopedagogia

$01 \quad 0,0$

Total

Dentre os objetivos apresentados nas dissertações e teses que estão na tabela 15a, o mais freqüente de todos $(0,3)$ foi elaborar proposta psicopedagógica para aplicação, seja com um aluno específico, seja na escola ou outra instituição. Este tipo de objetivo é coerente com aquilo que a Psicopedagogia se propõe: uma área de conhecimento com ênfase na prática. Na elaboração de uma proposta, a intenção neste tipo de objetivo é a aplicação prática, em conformidade com aquilo que no momento a sociedade elege como mais importante: soluções eficientes e práticas. Neste caso, a Psicopedagogia seria vista como uma técnica para prevenir ou resolver problemas de aprendizagem. O psicopedagogo previne, cura problemas e distúrbios de aprendizagem por meio de propostas elaboradas com finalidade prática.

Outro tipo de objetivo que apareceu nos trabalhos com maior freqüência $(0,2)$ foi conceituar e diagnosticar os problemas de aprendizagem de determinado(s) aluno(s) revelando por um lado um interesse teórico no assunto, mas por outro, objetivos práticos. Não queremos dizer que haja problema em se traçar um perfil mais relacionado com a prática. O problema é uma prática sem uma prévia reflexão ou a falta de uma reflexão seguida da prática de maneira a reproduzir aquilo que já se encontra instalado no âmbito educacional. Embora sejam diferentes uns dos outros, podemos fazer as seguintes observações sobre os outros objetivos: uma preocupação em dar uma identidade à psicopedagogia e conseqüentemente ao profissional psicopedagogo, considerando que é 
uma área de conhecimento nova. Isto pode ser observado nos objetivos "traçar o perfil do psicopedagogo", "opinião dos alunos sobre o curso de Psicopedagogia", "estruturar a Psicopedagogia como campo de conhecimento prático, docente e clínico; buscar uma fundamentação teórica para a Psicopedagogia”. O que acaba chamando a atenção é que se essa identidade precisa ser buscada e construída é porque de certa forma ela ainda não existe, portanto, ainda não podendo ser entendida como área de conhecimento autônoma que se estende além da Psicologia e Pedagogia.

Um outro tipo de objetivo que apareceu dentre esses foi analisar o discurso pedagógico a respeito da "adolescência", levando em conta seus aspectos históricos, para apontar sua fragilidade quando não se leva em conta os aspectos sócio históricos, o único objetivo que revela uma preocupação mais crítica em relação ao assunto abordado.

Por fim, temos três outros objetivos mais específicos às referentes teses com apenas uma aparição: identificar a situação existencial do idoso de classe média, verificar se atividades de "domínio espacial" produzem efeitos na superação do egocentrismo infantil e buscar as idéias de Piaget sobre aprendizagem nos documentos e relatos sobre a prática psicopedagógica na escola, relativa a uma determinada Secretaria da Educação. Vale lembrar que o primeiro deles foi acompanhado de um segundo objetivo no mesmo, de trabalho de elaboração e aplicação de uma proposta pedagógica direcionada para esta população reafirmando mais uma vez a tendência para adotarem esse tipo de objetivo.

Na tabela $15 b$ temos a frequiência e proporção dos objetivos traçados nas dissertações e teses analisadas dos programas de Pós-graduação das faculdades de Psicologia. 
TABELA 15b - Frequiência e proporção de dissertações e teses segundo os objetivos traçados nas pesquisas dos programas de pós-graduação das faculdades de Psicologia

\begin{tabular}{lcc}
\hline \multicolumn{1}{c}{ Objetivos } & frequência & proporção \\
- Conceituar e diagnosticar os problemas de aprendizagem de & 01 & 0,2 \\
$\begin{array}{l}\text { determinado(s) aluno(s) } \\
\text { - Descrever "esquemas" comuns utilizados pela criança no processo }\end{array}$ & 01 & 0,2 \\
$\begin{array}{l}\text { de construção de dois sistemas simbólicos } \\
\text { - Rever o conceito de conhecimento na obra de Freud para estabelecer }\end{array}$ & 01 & 0,2 \\
$\begin{array}{l}\text { seus desdobramentos no contexto da psicose infantil } \\
\text { - Demonstrar a eficiência do trabalho de Oficina Criativa } \\
\text { - Analisar a construção do conhecimento por intermédio de aspectos } \\
\text { operatórios e individuais e de relações inter individuais }\end{array}$ & 01 & 0,2 \\
- Comparar a realização de crianças retardadas mentais em uma prova \\
$\begin{array}{l}\text { de prontidão e uma de percepção visomotora com o desempenho } \\
\text { num material de ensino de leitura em nível e alfabetização }\end{array}$ & 01 & 0,2 \\
$\quad$ Total & $\mathbf{0 6}$ & $\mathbf{0 1}$ \\
\hline
\end{tabular}

Para os trabalhos apresentados no curso de pós-graduação das faculdades de Psicologia não houve uma tendência nos objetivos traçados nos trabalhos. Dos seis trabalhos analisados houve seis objetivos diferentes entre si, embora seja importante lembrar que em um deles se repete a tendência da elaboração da proposta pedagógica com máxima frequência nos objetivos das dissertações e teses da ANPED. No entanto, nesse caso a proposta já está elaborada; ela apenas terá que ser aplicada para ser comprovada, tentando se aproximar do tipo de pesquisa positivista na qual é realizado um experimento e ele pode ou não ser comprovado. Nos demais trabalhos o que chama a atenção é a especificidade de seus objetivos caminhando principalmente em duas linhas teóricas: 
piagetiana e psicanalítica. Esses trabalhos constam da aplicação desses referenciais para comprovação de algum tipo de objetivo prático traçado.

Na tabela 15c temos a freqüência e proporção dos objetivos traçados nas dissertações e teses analisadas dos programas de Pós-graduação das faculdades de Educação.

TABELA 15c - Freqüência e proporção de dissertações e teses segundo os objetivos traçados nas pesquisas dos programas de pós-graduação das faculdades de Educação

\section{Objetivos}

Elaborar proposta psicopedagógica

Analisar os campos semântico-conceptual e léxico-semântico

Discutir os limites da psicopedagogia quando não se leva em consideração o Inconsciente da Psicanálise.

Total frequência

01

01

01

03 proporção

0,3

0,3

0,3

Nos cursos de pós-graduação das faculdades de Educação vemos um trabalho que foca o objetivo de elaborar uma proposta psicopedagógica repetindo o padrão anterior. Temos um trabalho que relaciona Psicanálise com Psicopedagogia e um trabalho mais voltado para objetivos da Lingüística: analisar os campos semântico-conceptual e léxicosemântico.

Buscando mais uma vez uma tendência cronológica, temos na década de 80 uma frequiência maior de trabalhos que procuram como objetivos nas dissertações e teses algum tipo de proposta psicopedagógica que vise uma aplicação prática. Com exceção de uma dissertação que apresenta um objetivo mais específico - verificar se atividades de "domínio espacial" produzem efeitos na superação do egocentrismo infantil e de um trabalho defendido em 1989, ou seja, um trabalho com uma tendência mais próxima dos anos 90, todos os outros de alguma forma apresentam algum tipo de proposta para colaboração com a nova área de conhecimento. Este último trabalho tem seu objetivo mais coerente com a tendência apresentada na primeira metade da década de 90 . 
Na primeira metade da década de 90 aproximadamente, todos os trabalhos analisados tinham como objetivo a preocupação em fundamentar ou analisar a Psicopedagogia enquanto área de conhecimento ou aspectos como a formação, perfil, objeto de trabalho do psicopedagogo, os meios, locais e relações de trabalho. Parece um momento em que os autores se preocupam com uma diferenciação da Psicopedagogia em relação a outras áreas do conhecimento, é uma busca da identidade da área em questão a partir de opiniões, de alunos de cursos de especialização, profissionais da área e dados teóricos, de uma maneira a deixar de entender a Psicopedagogia de maneira intuitiva e passar a olhá-la com identidade própria. Na segunda metade da década, volta a tendência em elaborar propostas psicopedagógicas para aplicação principalmente nas escolas com alunos que apresentam problemas de aprendizagem ou com intenção preventiva parecendo haver uma intenção de "provar" que a Psicopedagogia "funciona". Com exceção de dois trabalhos com objetivos mais específicos de analisar o discurso pedagógico de maneira mais reflexiva, todos os outros apresentam a tendência anterior apresentada.

A seguir temos a tabela 16a que traz os tipos de pesquisa (empírica ou teórica) realizados nas dissertações e teses da $A N P E D$ selecionadas para esta pesquisa.

TABELA 16a - Freqüência e proporção de dissertações e teses da ANPED segundo o tipo de pesquisa realizada

\begin{tabular}{lccc}
\hline & Tipo de pesquisa & frequência & proporção \\
Empírica & & 09 & 0,6 \\
Teórica & Total & 06 & 0,4 \\
& \multirow{2}{*}{ Total } & $\mathbf{1 5}$ & $\mathbf{0 1}$ \\
\hline
\end{tabular}

Dentre os tipos de pesquisa utilizados nas dissertações e teses analisadas podemos observar na tabela 16a que predominou a empírica, ou seja, nove dos $15(0,6)$ trabalhos são pesquisas empíricas e seis $(0,4)$ foram pesquisas teóricas. Ou ainda, olhando para todos os 
trabalhos em conjunto temos 16 pesquisas empíricas para oito teóricas. Fica evidente a tendência da pesquisa empírica nos trabalhos, ou seja, aproximadamente dois terços deles optaram por um tipo de pesquisa empírica o que é condizente com o que já discutimos sobre a área de conhecimento psicopedagógica que se pretende uma prática e cada vez mais se adequar ao tipo de sociedade vigente.

A tabela $16 \mathrm{~b}$ traz os tipos de pesquisa (empírica ou teórica) realizados nas dissertações e teses dos programas de Pós-graduação das faculdades de Psicologia selecionadas para esta pesquisa.

TABELA 16b - Frequiência e proporção de dissertações e teses dos programas de pós-graduação das faculdades de Psicologia segundo o tipo de pesquisa realizada

\begin{tabular}{lccc}
\hline & Tipo de pesquisa & frequência & proporção \\
Empírica & & 05 & 0,8 \\
Teórica & Total & 01 & 0,2 \\
& \multirow{2}{*}{ Total } & $\mathbf{0 6}$ & $\mathbf{0 1}$ \\
\hline
\end{tabular}

A mesma tendência se repete com os trabalhos da Psicologia PUC e USP: 0,8 constam de pesquisas empíricas e 0,2 representando uma pesquisa teórica.

A tabela 16c traz os tipos de pesquisa (empírica ou teórica) realizados nas dissertações e teses dos programas de Pós-graduação das faculdades de Educação selecionadas para esta pesquisa.

TABELA 16c - Freqüência e proporção de dissertações e teses dos programas de pós-graduação das faculdades de Educação segundo o tipo de pesquisa realizada

Tipo de pesquisa

Empírica

Teórica frequência

02

01 proporção

0,7

0,3 
Mais uma vez aqui a tendência empírica se repete, com a proporção de 0,3 para pesquisas teóricas e 0,7 para pesquisas empíricas.

Como tendência cronológica, temos nos anos 80 todas as pesquisas com exceção da última defendida em 1989, como pesquisa do tipo empírica. Até a metade da década de 90 houve um aumento das pesquisas do tipo teórica, mas no entanto a marca da prática refletido nas pesquisas empíricas continua aparecendo e esta tendência volta a crescer a partir da segunda metade da década de 90 até início do novo século. Essas pesquisas do tipo empírica na grande maioria das vezes são típicas pesquisas positivistas sem procurar atentar para uma reflexão voltada para um questionamento da área estudada. Essas pesquisas são na maior parte das vezes para confirmar ou justificar os próprios conceitos da Psicopedagogia.

A seguir temos a tabela 17a que mostra a freqüência e proporção de dissertações e teses da ANPED segundo o referencial teórico adotado.

TABELA 17a - Freqüência e proporção de dissertações e teses da ANPED segundo o referencial teórico adotado

\begin{tabular}{lcc}
\hline \multicolumn{1}{c}{ Referencial teórico/autor } & frequência & proporção \\
Epistemologia Genética (Piaget) & 03 & 0,1 \\
Epistemologia Convergente de Jorge Visca & 02 & 0,1 \\
Sócio-interacionismo de Vygotsky & 02 & 0,1 \\
\hline
\end{tabular}




\begin{tabular}{|c|c|c|}
\hline Alicia Fernandez/Sarah Pain & 02 & 0,1 \\
\hline outros $^{35}$ & 01 & 0,0 \\
\hline Não adota & 01 & 0,0 \\
\hline - & 19 & 0,6 \\
\hline Total & 30 & 1 \\
\hline
\end{tabular}

O referencial teórico mais utilizado foi a Epistemologia Genética de Jean Piaget, em três trabalhos, seguida da Epistemologia Convergente de Jorge Visca (dois trabalhos), do Sócio-interacionismo de Vygotsky (dois trabalhos) e Alicia Fernandez/ Sarah Pain (dois trabalhos). Os demais autores e referenciais teóricos apareceram na mesma proporção, uma aparição. Vale lembrar que o referencial da Epistemologia Genética embora só apareça em três trabalhos como referencial, ele é citado e comentado em praticamente todos os trabalhos.

Com exceção de alguns autores que deixam bem especificado seu referencial teórico, os demais utilizaram diversos referenciais no mesmo trabalho. Como podemos observar na tabela, há mais itens com autores e referenciais teóricos do que o número de trabalhos analisados. Na maior parte das vezes, ao invés de seguirem um referencial apenas, houve uma tendência de se citar vários autores com pensamentos diversos e em alguns casos antagônicos em um mesmo trabalho. Houve uma tentativa de procurar mais mostrar o que cada autor pensa sobre aprendizagem ou demais assuntos, do que utilizá-los para fazer uma análise da pesquisa em questão.

\footnotetext{
${ }^{35}$ Outros refere-se à dissertação que entrevistou diversos autores e que precisou citá-los no seu referencial teórico.

- Referenciais ou autores utilizados apenas uma vez nos trabalhos analisados: Psicomotricidade Relacional de Lapierre, Pedagogia de Freinet, Rich, De La Puente, Rogers, Gestalt terapia, Wallon, Erikson, Paulo Freire, Bruner, Fonseca, Valett, Ausubel, Weiss, Macedo, Hoose et Worth Vaillant, Figueiredo, Figueira, Vasconcelos, Parrat-Dayan.
} 
No trabalho "A invenção da adolescência no discurso psicopedagógico", embora o autor tenha utilizado vários autores, o fez para delinear contextos históricos e foram autores que convergem de uma certa forma em termos teóricos.

No trabalho "Psicopedagogia: um perfil profissional em conflito", a autora entrevistou diversos profissionais da área que são autores também (Lino de Macedo, Alicia Fernandez, Elcie Fazano Massini, Marta Khol, Maria Helena Novaes, Aglael Borges, Maria Luiza Gomes Pereira, Ana Maria de Castro Magioli, Celma Vilaça, Wilma Barata Barbosa, Fany Plaschta, Sonia Fonseca, Maria Célia Rosetto, Haydée Mayae), portanto, teve de citar todos os entrevistados em seu referencial teórico.

Outro fato comum foi o autor apresentar um referencial teórico como adotado, mas no decorrer do trabalho ele acabar utilizando outro referencial que não aquele primeiro. Por exemplo, no trabalho Psicopedagogia Inter-Ativa: ação psicopedagógica institucional baseada em uma convergência teórica, o referencial utilizado engloba quatro teorias de diferentes autores mas que possuem aspectos semelhantes segundo a autora do trabalho. Esses autores apresentam aspectos comuns como, por exemplo, a importância que dão a adaptação à realidade. O produto deve ser um indivíduo autônomo preparado para agir e transformar com consciência (Maman, 1997). No entanto, não é explicado o que estes autores entendem por autonomia e em que direção deve se dirigir tal transformação, além de não se especificar também, qual o tipo de consciência que o indivíduo deve atingir. Mais do que isto, no decorrer do trabalho observamos que ele não caminha no sentido que conduza os alunos à autonomia. Embora ela adote esse referencial teórico, vemos durante o trabalho a utilização constante da Epistemologia Genética de Jean Piaget, 
utilizando diversas citações. Parece que esse referencial acaba dando suporte a ela para embasar suas hipóteses sobre fracasso escolar do que os outros que ela explicita como sendo referenciais adotados. Fica evidente também que muitas das explicações que ela dá para os problemas de aprendizagem têm suporte na Teoria da Carência Cultural. Vemos uma miscelânea de referenciais num mesmo trabalho desarticulados uns com os outros e sem a utilização de nenhuma crítica em relação a eles.

A falta de questionamento dos referenciais teóricos também ocorre, por exemplo com o autor Jorge Visca que defende como pré requisito para o sucesso na aprendizagem a resolução das ansiedades e a adaptação ativa à realidade, a criatividade, projetos etc. A aprendizagem, segundo Visca, para a autora: "somatória de informação dos integrantes do grupo, transformação de quantidade em qualidade. Resolução de ansiedades, adaptação ativa à realidade, criatividade, projetos, etc". Fica a pergunta: é possível ser criativo quando só há espaço para a adaptação? Este seria um dos questionamentos possíveis, mas que não ocorre no trabalho. Parece que a criatividade acaba aparecendo mais como uma obrigação para adaptação por mais contraditório que isso pareça. A autora acaba partindo de um princípio que destoa do autor escolhido.

A seguir temos a tabela $17 \mathrm{~b}$ que mostra a frequiência e proporção de dissertações e teses dos programas de Pós-graduação das faculdades de Psicologia segundo o referencial teórico adotado.

TABELA 17b - Frequiência e proporção de dissertações e teses dos programas de pós-graduação das faculdades de Psicologia segundo o referencial teórico adotado

Referencial teórico/autor

Epistemologia Genética (Piaget)

Psicanálise Freud/Lacan frequência

03

02 proporção

0,3

0,2 
Como no caso dos trabalhos da ANPED, o referencial mais utilizado foi a Epistemologia Genética de Jean Piaget $(0,3)$. Em seguida a maior aparição foi para a Psicanálise de Freud e Lacan (0,2) e Psicologia Analítica de Jung, Psicodrama de Moreno e Witter, Copit e Poppovic sendo utilizados uma vez apenas nos trabalhos. Aqui também encontramos referenciais e autores acima do número de trabalhos analisados. Mas aqui houve uma tendência de serem mais coerentes com os autores utilizados e com a pesquisa realizada.

A seguir temos a tabela 17c que mostra a freqüência e proporção de dissertações e teses dos programas de Pós-graduação das faculdades de Educação segundo o referencial teórico adotado.

TABELA 17c - Frequiência e proporção de dissertações e teses dos programas de pós-graduação das faculdades de Educação segundo o referencial teórico adotado

\begin{tabular}{lcc}
\hline \multicolumn{1}{c}{ Referencial teórico/autor } & frequência & proporção \\
Epistemologia Genética (Piaget) & 01 & 0,2 \\
Construtivismo de Piaget/ Emila Ferreiro/ Teberosky & 01 & 0,2 \\
Psicanálise de Freud/Lacan & 01 & 0,2 \\
Psicopedagogia de Alicia Fernandez & 01 & 0,2 \\
Gutierrez, Snyders, Kneller e Pais, Barbosa, Genouvrier, & 01 & 0,2 \\
Pottier, Robin & & 0,2 \\
Sarah Pain & 01 & $\mathbf{0 1}$ \\
TOTAL & $\mathbf{0 6}$ & \\
\hline
\end{tabular}

Referenciais ou autores utilizados apenas uma vez nos trabalhos analisados: Psicologia Analítica de Jung, Psicodrama de Moreno, Witter, Copit e Poppovic. 
Aqui, todos os referenciais citados na tabela apareceram em igual proporção, chamando a atenção novamente para o fato de serem utilizados mais referenciais e autores do que o número de trabalhos analisados.

Cronologicamente não é possível estabelecer tendências teóricas utilizadas nas diferentes décadas analisadas. Mesmo os autores mais utilizados distribuem-se de uma maneira desigual dentro das décadas de 80, 90 e nos anos 2000 e 2001.

Segundo Szterling (2000) a Psicopedagogia não possui ainda um campo teórico sistematizado. Os profissionais dessa área utilizam diversas abordagens ou partes dessas abordagens para poder fundamentar seu trabalho clínico ou institucional. Bossa (2000) observa que mesmo nos cursos de especialização em Psicopedagogia no Brasil, ainda não há um conteúdo programático ou estrutura curricular comum, embora podemos ver um maior destaque para autoras como Sarah Pain e Alicia Fernandez nesses cursos. Conforme Szterling citando Vorcaro: “hoje existem [no Brasil] tantas psicopedagogias quantos psicopedagogos"(SZTERLING, 2000:08).

A tabela 18a mostra as conclusões elaboradas pelos autores das dissertações e teses analisadas da $A N P E D$. Mais uma vez, a frequiência da tabela é relativa às conclusões e não ao número de trabalhos analisados.

TABELA 18a - Dissertações e teses da ANPED segundo as conclusões tiradas nas pesquisas em dados brutos e proporção

\section{Conclusões}

- Distúrbios de aprendizagem são causados por fatores emocionais, frequência proporção

04

0,2 
orgânicos, sociais (família), pedagógicos (escola), econômicos

- Professores precisam de melhor formação

- A Psicopedagogia deve se ater à prática

- Psicopedagogia como nova área que preenche falta entre Psicologia

e Pedagogia

- Discurso psicopedagógico trata a adolescência como um universal ahistórico e natural/Psicopedagogia não é natural, mas é produzida por uma dinâmica social

- Psicopedagogia como campo de atuação interdisciplinar e multidisciplinar

- Proposta psicopedagógica de desenvolver diversas potencialidades que são requisitos para a aprendizagem é viável e necessária

- A prática na Secretaria da Educação se desenvolveu numa proposta eclética sobressaindo a matriz romântica

- Reflexão como um ato importante para compreender fenômenos diferenciando o que é dificuldade de aprendizagem do que é aprendizagem normal

- Psicopedagogia possibilita autoconhecimento

- Não há identidade entre Psicopedagogia e psicopedagogos

- O olhar da psicopedagogia se condensa nas modalidades de aprendizagem

- As atividades de "domínio espacial" produzem efeitos na superação do egocentrismo infantil

- Psicopedagogia com falta de nitidez conceitual e em estado de présaber

- O atendimento psicopedagógico se mostrou eficaz

- Os idosos entrevistados não apresentam problemas de alimentação, mas apresentam problemas de saúde. O aspecto social tem influência sobre a velhice. Os idosos consideram a assistência familiar como prioritária.

- Psicopedagogia mais evoluída na Argentina do que no Brasil

$01 \quad 0,0$

- Os cursos de Psicopedagogia não cumprem as idéias da $01 \quad 0,0$ Psicopedagogia principalmente em relação à afetividade 
Segundo dados da tabela 18a, observamos as diversas conclusões. Dentre elas, a que apareceu numa maior proporção foi que distúrbios de aprendizagem são causados por fatores emocionais, orgânicos, sociais (família), pedagógicos (escola), econômicos em quatro trabalhos dos 15; a seguir temos em três dos 15 trabalhos que os professores precisam de melhor formação. Com duas aparições considerando os 15 trabalhos tivemos as seguintes conclusões: Psicopedagogia como nova área que preenche falta entre Psicologia e Pedagogia; Proposta psicopedagógica de desenvolver diversas potencialidades que são requisitos para a aprendizagem é viável e necessária; Discurso psicopedagógico trata a adolescência como um universal a-histórico $e$ natural/Psicopedagogia não é natural, mas é produzida por uma dinâmica social; Psicopedagogia como campo de atuação interdisciplinar e multidisciplinar; $A$ Psicopedagogia deve se ater à prática. As demais conclusões apareceram em apenas um dos trabalhos analisados. A maior parte delas acaba por expressar os próprios conceitos da Psicopedagogia. É como se os trabalhos realizados fossem feitos para reafirmar os próprios conceitos já instalados pela Psicopedagogia. Os autores acabam por enxergar em seus experimentos aquilo que não tem a intenção de contestar. Os únicos casos em que este tipo de conclusão não aparecem foram em trabalhos que procuraram ser mais reflexivos e que chegaram a conclusões mais críticas como: discurso psicopedagógico trata a adolescência como um universal a-histórico e natural/Psicopedagogia não é natural, mas é produzida por uma dinâmica social e a prática na Secretaria da Educação se desenvolveu numa proposta eclética sobressaindo a matriz romântica. No entanto vale lembrar que isso só ocorreu em três de 15 trabalhos. Um deles, por exemplo, que caminhou nessa direção mais crítica, apontou para a fragilidade do termo "adolescência" quando utilizado no discurso psicopedagógico sem levar em consideração seu aspecto histórico, além de mostrar que normalmente esse termo é utilizado na psicopedagogia de maneira a-histórica e natural. 
O maior número de conclusões vão na mesma direção da Psicopedagogia, confirmando seu discurso de que os problemas de aprendizagem advêm de fatores emocionais, orgânicos, socioculturais e pedagógicos e em outra, que a Psicopedagogia vem para suprir a falta que há na Psicologia e Pedagogia além de propiciar autoconhecimento. Essas duas conclusões foram tiradas a partir do próprio discurso teórico psicopedagógico.

Algumas conclusões chamam a atenção no sentido do que foi concluído; aspectos que o trabalho como um todo não se propôs e não analisou. Ou seja, fica o estranhamento de como o autor chegou àquela conclusão. Um exemplo são os dois trabalhos que concluem que a Psicopedagogia deve se ater à prática. Não fica claro que tipo de pesquisa foi feita para se chegar a esta conclusão. Aqui mais uma vez percebemos a repetição do discurso psicopedagógico como conclusão, independentemente se houve dados que confirmassem este aspecto ou não na pesquisa realizada.

Em outra conclusão, é apontada a importância da reflexão para se diferenciar o que é um problema de aprendizagem do que é uma aprendizagem normal. Como já foi dito anteriormente, a reflexão é um ato muito importante em qualquer trabalho científico. No entanto, neste caso, a reflexão foi utilizada de maneira a diferenciar padrões préestabelecidos. Seria interessante poder refletir sobre estes padrões e os critérios para o estabelecimento dos mesmos. 
Houve um grupo de conclusões mais específicas que vieram de trabalhos com objetivos mais específicos também, por exemplo, um trabalho que aborda problemas vivenciados por pessoas da terceira idade.

A tabela $18 \mathrm{~b}$ mostra as conclusões elaboradas pelos autores das dissertações e teses analisadas do programa de pós-graduação das faculdades de Psicologia.

TABELA 18b - Dissertações e teses do programa de pós-graduação das faculdades de Psicologia segundo as conclusões tiradas nas pesquisas em dados brutos e proporção

\section{Conclusões}

- Psicanálise pode contribuir para a psicopedagogia

- Ambos os esquemas tratados no trabalho não são totalmente autônomos e podem servir como suporte para um trabalho psicopedagógico que procure fortalecer um domínio simbólico ainda não bem desenvolvido.

- As performances das crianças nos jogos apontaram a mesma direção das respostas obtidas nas duas aplicações das provas operatórias e no segundo experimento, as intervenções puderam possibilitar a construção do conhecimento.

- A Oficina Criativa ajuda experienciar a aprendizagem de forma a ampliá-la.

- Há três eixos referenciais para a análise das relações entre psicose infantil e conhecimento

- Crianças consideradas retardadas mentais alunas da APAE podem aprender a ler num ritmo próprio e com métodos especiais que não

\section{frequência proporção}

$01 \quad 0,2$

$01 \quad 0,2$

01

0,2

01

01

0,2

01 
necessariamente são aqueles impostos pela elite cultural.

Nas conclusões da pós-graduação das faculdades de Psicologia não houve nenhuma que teve uma frequência superior às demais, uma vez que todas elas foram mais específicas de acordo com o objetivo proposto pelos trabalhos. A diferença que notamos em relação às conclusões dos trabalhos das outras tabelas é que nenhum deles procura confirmar o discurso pedagógico no sentido de repeti-lo. Isso não quer dizer que não haja críticas a serem feitas em relação a essas conclusões.

A tabela 18c mostra as conclusões elaboradas pelos autores das dissertações e teses analisadas do programa de pós-graduação das faculdades de Educação.

TABELA 18c - Dissertações e teses do programa de pós-graduação das faculdades de Educação segundo as conclusões tiradas nas pesquisas em dados brutos e proporção

\section{Conclusões}

- Psicanálise pode contribuir para a psicopedagogia

- Psicologia genética pode contribuir para a psicopedagogia

- Os temas preferidos pelos alunos devem ser considerados na seleção de conteúdos que a escola realiza de forma a ampliar o léxico individual dos alunos.

- Toda criança é capaz de aprender, logo deve-se discutir como vem sendo conduzido o processo ensino aprendizagem do aluno na escola

$\begin{array}{cc}\text { Freqüiência } & \text { proporção } \\ 01 & 0,3 \\ 01 & 0,3 \\ 01 & 0,3\end{array}$

01 0,3

04

\section{1}

Na tabela 18c também não temos conclusões que apareçam em mais de um trabalho. Chamam a atenção as conclusões que procuram mostrar que outras áreas de 
conhecimento ou referenciais podem contribuir para a Psicopedagogia como a Psicanálise e a Psicologia Genética.

Cronologicamente não observamos na década de 80 nenhuma tendência específica. O que é possível ver é a partir de 1989 o aparecimento de trabalhos preocupados com conclusões mais reflexivas, algumas procurando questionar a Psicopedagogia enquanto área de conhecimento ou seu discurso, mas na maior parte das vezes concluem uma reafirmação daquilo que a Psicopedagogia defende, em outras vezes, tentam justificar certos pressupostos como, por exemplo, no trabalho que diz que a Psicopedagogia não está bem fundamentada pois ela se encontra num estágio de pré-saber, logo ficando subentendido que um dia se tornará um saber. Em outros casos, poucos infelizmente, os autores conseguem chegar a uma conclusão mais crítica dando margem a um possível avanço na área como já comentado em parágrafos anteriores.

A tabela 19a traz o número e proporção de dissertações e teses que apresentam os termos adaptação e emancipação nos trabalhos da ANPED.

TABELA 19a - Freqüência e proporção de dissertações e teses da $A N P E D$ que apresentam os termos adaptação e emancipação

\begin{tabular}{ccc}
\hline & frequência & proporção \\
Adaptação & 10 & 0,6 \\
Emancipação & 03 & 0,2 \\
Não cita adaptação e & 03 & 0,2 \\
emancipação & & \\
Total & $\mathbf{1 6}$ & $\mathbf{0 1}$ \\
\hline
\end{tabular}

Como podemos observar, a palavra adaptação foi citada em 10 dos 15 trabalhos analisados. Nos 10 trabalhos, a palavra adaptação aparece na maior parte das vezes no capítulo referente a teoria utilizada e/ou na parte histórica da dissertação ou tese, como uma das facetas da Educação, ou seja, um dos objetivos da Educação é o de adaptar os 
indivíduos à sociedade ou no sentido defendido pela Epistemologia Genética como sendo a adaptação o mecanismo que possibilita sobrevivência. Em um dos trabalhos a palavra aparece para lembrar que a escola brasileira se baseou - se adaptou - ao modelo europeu de escola e educação. Até então o termo aparece para descrever questões históricas ou conceituais relacionadas à Educação e não demonstraram se o autor do trabalho concorda ou não com apenas este tipo de postura em educação. "Não podemos, no entanto, esquecer que a educação tem outro sentido, o de atuar sobre a pessoa, para torná-la capaz e adaptar-se a um modelo previamente escolhido" (ZILIO, 1993:15). Neste outro trabalho a palavra adaptação aparece em um sentido mais preocupado com a crítica: "A crítica e a denúncia do caráter adaptativo das práticas psicológicas invadem a literatura dos anos 80... (BECKER, 1998:101)'”. Nesse trabalho a palavra adaptação aparece em um contexto histórico, mas a autora se utiliza desse contexto para fazer críticas pertinentes à Psicologia e Pedagogia dos anos 80. Nesse mesmo trabalho aparece o termo emancipação também em um tom reflexivo: "será que o fato de se criarem condições para o desenvolvimento da reciprocidade e da cooperação, em sala de aula, significa que a escola possa tornar-se um instrumento poderoso de emancipação e de desalienação, a ponto de promover mudanças estruturais na sociedade?” (BECKER, 1998:101). A autora também discute os termos heteronomia e autonomia mas não segundo o referencial de Adorno.

Em mais dois trabalhos aparece o termo emancipação explicitado. A dissertação "Atendimento psicopedagógico e as dificuldades de aprendizagem" cita ambos os termos (adaptação e emancipação). Em uma delas, a palavra adaptação aparece num sentido daquele utilizado na teoria da carência cultural: "A escola terá que adaptar-se às crianças, à variedade humana" (SGARBOSSA, 1997:15). Ou ainda:

\footnotetext{
"O atual contexto escolar, é ineficiente às crianças que possuem dificuldades de aprendizagem, pois impossibilita a
} 
adaptação dos objetivos, em se fazer um ensino democrático, com decisão coletiva sobre os conteúdos de ensino, que representem os interesses dos alunos e que, principalmente, considere as necessidades de cada um. (SGARBOSSA, 1997:13)'”.

Em outro momento, ao citar as condições para que a aprendizagem ocorra, volta a usar o termo adaptação: "possuir boa adaptação pessoal e familiar" (SGARBOSSA, 1997:19). Finalmente, cita emancipação em uma frase que procura refletir sobre a teoria da alfabetização:

"Pensamos que no campo da teoria da alfabetização nada é mais importante do que olhar cuidadosamente a percepção do nosso perceber, de pensar sobre o pensamento, de interpretar nossas interpretações, pois comungamos a idéia de que a mesma é um projeto emancipador” (SGARBOSSA, 1997:16).

O outro trabalho que cita o termo emancipação é "A psicopedagogia no Brasil: contribuições a partir da prática" ao comentar as metas relacionadas à Psicopedagogia: " $a$ Psicopedagogia busca a sua emancipação, na porção em que investe na elaboração de um instrumento próprio, bem como se reforce por meio do estabelecimento de uma legislação mais precisa..." (BOSSA, 1993:122).

O mais freqüente foi o aparecimento de uma aparente defesa de uma educação para o "crescimento" e "desenvolvimento" do indivíduo, mas sem uma estruturação de como isso deveria se dar. No entanto, no decorrer de um dos trabalhos esta postura se mostra contraditória; a palavra adaptação acaba aparecendo para apontar o papel do psicopedagogo como um profissional que deve ajudar o aluno a se adaptar a escola e corresponder a suas expectativas. Matioda (1998) ao se referir ao trabalho do 
psicopedagogo escreve: "compreende-se que apesar de todo o esforço que o aluno dispensa, dificilmente conseguirá corresponder às expectativas escolares sem um apoio externo... A Psicopedagogia vem ajudar nessa inserção” (MATIODA, 1998:56). E no decorrer de seu trabalho continua confirmando essa posição ao comentar sobre o professor e o aluno em sala de aula e seus problemas:

"O professor que tiver em sua sala de aula alunos com problemas de aprendizagem estará diante da desafiadora tarefa de ajudálos a se adaptarem à escola. Esse tipo de criança não é necessariamente um deficiente intelectual. Existem outras causas que podem provocar a lentidão da aprendizagem como distúrbios emocionais, problemas físicos, falta de incentivo, hábitos inadequados de estudo, condições familiares estáveis e também deficiência do próprio ensino” (MATIODA, 1998:163).

É importante lembrar que a adaptação em termos de conhecimento da cultura e das regras racionais é um dos passos para uma posterior emancipação. Mas em nenhum dos trabalhos este aspecto foi discutido ou pelo menos citado.

Houve três trabalhos em que não foram citados os termos adaptação e emancipação, revelando que para alguns autores estes temas não são fonte de interesse ou importância. No entanto, em um deles "A atuação do profissional em Psicopedagogia e a formação do psicopedagogo em São Paulo no período de 1980 a 1990”, que embora não cite os termos adaptação ou emancipação não defendendo explicitamente nenhuma das duas posições, é um trabalho voltado para uma educação emancipatória, pois ele não se contenta em apenas aplicar a teoria sem uma prévia reflexão. Pelo contrário, a autora faz um estudo da Psicopedagogia em São Paulo enquanto área de conhecimento e profissão de forma crítica, mostrando que da maneira que a Psicopedagogia está estruturada e é pretendida está servindo a interesses coorporativistas, ou seja, apontou seus aspectos 
regressivos e que não contribuem para uma educação emancipatória. No entanto, este item será melhor discutido nas tabelas 20a, 20b, 20c.

A tabela 19b traz o número e proporção de dissertações e teses que apresentam os termos adaptação e emancipação do programa de Pós-graduação das faculdades de Psicologia.

TABELA 19b - Frequiência e proporção de dissertações e teses do programa de pós-graduação das faculdades de Psicologia que apresentam os termos adaptação e emancipação

Frequiência proporção

$\begin{array}{lll}\text { Adaptação } & 04 & 0,7 \\ \text { cita adaptação e } & 02 & 0,3\end{array}$

emancipação

Emancipação $\quad 00 \quad 00$

$\begin{array}{lll}\text { Total } & 06 & 01\end{array}$

Como podemos observar, em quatro dos seis trabalhos foi citado o termo adaptação. Em dois deles no sentido piagetiano do termo como já havia ocorrido com alguns trabalhos da ANPED:

\footnotetext{
"Já o jogo de construção tem o objetivo de possibilitar a reconstrução do real, seja ela por intermédio da construção de um objeto, de uma cena acontecida, de uma dramatização que encena a vida, a serviço de uma melhor adaptação à vida social, afetiva e ao trabalho". (WECHSLER, 1994:37)
}

No mesmo trabalho cita novamente o termo ao explicar a metodologia utilizada

\footnotetext{
“... mas sobretudo levar nossos sujeitos a tomarem consciência de seus próprios pensamentos, ou seja da função que eles estariam assumindo, o que poderia lhes propiciar uma nova organização interna, expressada por uma melhor adaptação externa, por via de uma ação de jogar mais eficaz" (WECHSLER, 1994:60).
}

Em ambos os casos a palavra aparece como aplicação da teoria de Piaget. 
No trabalho "Oficina criativa e psicopedagogia", o termo adaptação é utilizado como uma conquista obtida a partir da aprendizagem, mais uma vez com o lema - aprender para se adaptar: "acredito que um processo de aprendizagem, desenvolvido de forma criativa, permite ao indivíduo elaborar suas habilidades cognitivas de forma mais completa, o que pode ter um papel importante para ele ser, estar, sentir, visualizar, imaginar, aprender, adaptar-se e ser criativo na sua vida” (ALLESSANDRINI, 1995:55).

No trabalho "Um estudo psicanalítico sobre a produção do conhecimento na criança psicótica" o termo adaptação é utilizado para se referir aos parâmetros de ação utilizados na psicose infantil quando esta não é analisada junto ao que ele nomeia de discurso do conhecimento ou quando é analisada nas intersecções com o discurso do conhecimento: "As práticas e intervenções que aqui são engendradas tomam, como parâmetros de ação, as idéias de inadaptação e inadequação social, o que envolve a necessidade de afastamento e exclusão...”(LIMA, 1998:139) “...A criança psicótica, no entanto, permanece tomada enquanto objeto, sendo suas produções suportes de readaptações, na perspectiva de uma estrita retificação de seus conteúdos aos cânones da realidade” (LIMA, 1998:139-140).

Os outros dois trabalhos não utilizaram e não se preocuparam com questões referentes aos termos adaptação e emancipação.

A tabela 19c traz o número e proporção de dissertações e teses que apresentam os termos adaptação e emancipação do programa de Pós-graduação das faculdades de Educação. 
TABELA 19c - Freqüência e proporção de dissertações e teses do programa de pós-graduação das faculdades de Educação que apresentam os termos adaptação e emancipação

\begin{tabular}{ccc}
\hline & frequência & proporção \\
Adaptação & 02 & 0,7 \\
Não cita adaptação e & 01 & 0,3 \\
emancipação & & \\
Emancipação & 00 & 00 \\
Total & $\mathbf{0 3}$ & $\mathbf{0 1}$ \\
\hline
\end{tabular}

Com exceção de um trabalho que não cita nenhum dos dois termos, os outros dois citam apenas o termo adaptação no sentido em que a Epistemologia Genética de Piaget utiliza: "A adaptação ocorre pelo equilibrio entre assimilação e acomodação". (TEIXEIRA, 1996:11). Este é um dos exemplos do uso do termo adaptação utilizado pela Epistemologia Genética no trabalho "Toda criança é capaz de aprender" ou ainda, "Piaget está interessado em comprovar experimentalmente suas especulações filosóficas sobre o nascimento e desenvolvimento das formas ou estruturas da inteligência; e em explicar como estas derivam daquelas, cumprindo uma única e mesma função adaptativa" (SZTERLING, 2000:25) no trabalho "Diálogo entre a psicanálise e a psicopedagogia: sobre a (im)possibilidade de aprender".

Partindo-se do princípio que as palavras adaptação e emancipação podem não ser explicitadas, elaboramos as tabelas 20a, 20b e 20c para ilustrar se o autor de cada trabalho analisado considera a Psicopedagogia como uma área mais voltada para uma educação adaptativa ou emancipatória, independentemente dos dois termos aparecerem ou não em seus trabalhos. O critério para definir que posição o trabalho defende foi o de observar inicialmente se as questões relacionadas com a educação voltada para adaptação e emancipação foram contempladas. No entanto, para serem contempladas não bastou serem 
citadas, mas sim apresentadas com um certo grau de coerência durante todo o trabalho. Para uma tese ou dissertação serem consideradas como defendendo uma posição de educação emancipatória, elas devem considerar o problema educacional não apenas como problema do aluno ou do professor ou da instituição seja escolar, familiar ou outra. Mas devem fazer uma crítica social apontando que devido à maneira como a sociedade está estruturada, a educação apresenta problemas que só poderão ser sanados de fato, mediante uma reorganização social. Ou seja, a sociedade administrada não admite uma educação emancipatória, não é possível que ambas convivam simultaneamente.

TABELA 20a - Freqüência e proporção de dissertações e teses da ANPED que apresentam a psicopedagogia voltada para uma educação adaptativa ou emancipatória

\begin{tabular}{ccc}
\hline & frequência & proporção \\
Educação adaptativa & 12 & 0,8 \\
Educação emancipatória & 03 & 0,2 \\
Total & $\mathbf{1 5}$ & $\mathbf{0 1}$ \\
\hline
\end{tabular}

Como podemos observar, a maior parte dos trabalhos $(0,8)$ dizem ser a Psicopedagogia uma área mais voltada para questões adaptativas relacionadas à educação. Vale lembrar que aqui a educação adaptativa é entendida como uma educação regressiva, que entende a adaptação para fins irracionais da sociedade. Este fato é importante ser explicitado para não ficar parecendo que há uma dicotomia, em outras palavras, para não parecer que a educação ou é emancipatória ou adaptativa. $\mathrm{Na}$ verdade a educação emancipatória depende da adaptação como já explicado no Capítulo 1, lembrando que se entende por adaptação conhecimentos adquiridos pela sociedade ao longo dos tempos. No entanto, este conhecimento deve ser refletido e não apenas entendido como mais uma informação memorizada ou sem conexão com a sociedade atual. 
O que foi observado em todos os trabalhos que apontam e defendem uma Psicopedagogia voltada para uma educação adaptativa foi a tendência de defenderem em sua parte teórica uma educação voltada para a autonomia enquanto crescimento e desenvolvimento do indivíduo. No entanto, entendem esse desenvolvimento como um vir a ser já determinado a priori bastando serem estimulados, da mesma maneira que as plantas crescem e se desenvolvem quando são regadas, e já sabemos qual será o resultado desse crescimento. É uma visão determinista e "biologizada" da educação. Não foi à toa que o referencial teórico mais utilizado nos trabalhos analisados foi o piagetiano. O sociointeracionismo entende a educação como resultado da interação entre o indivíduo e o meio, ou seja, um meio biológico enquanto número de estímulos suficientes para desenvolver as qualidades do indivíduo que é igual aos outros em possibilidades para que se torne alguém "educado". Temos segundo esse referencial a possibilidade de controle e previsibilidade do resultado. São trabalhos que reproduzem o esquema social em que vivemos, no qual os estímulos já possuem a priori a resposta esperada, em que tudo é controlado de maneira a ter resultados eficientes. Os resultados, os fins são mais importantes do que o processo. Dessa forma, não há possibilidade de autonomia e, portanto, de emancipação desses indivíduos, já que eles já são determinados mesmo antes de serem "educados" dando margem a uma educação heteronômica. Se não se tornam como o modelo de indivíduo "normal", precisam automaticamente de um tratamento para desenvolverem as habilidades consideradas normais e indispensáveis para que um ser humano seja considerado ser humano. Ou ainda, seguindo o esquema da teoria da carência cultural, altera-se a metodologia educativa para atender e adaptar-se aos alunos diferentes estereotipando-os, logo não possibilitando emancipação. Por isso, umas das alternativas é a criação de propostas metodológicas de interação entre o professor e o aluno, ou entre o 
aluno e o psicopedagogo de maneira que o aluno venha a se inserir no contexto escolar e de uma maneira mais ampla, no contexto social. Não foi à toa que dentre os objetivos das dissertações e teses predominaram sobre os demais a criação de propostas psicopedagógicas para alunos, escolas e demais instituições com a intenção de adaptar o aluno ao contexto escolar e de aprendizagem:

\footnotetext{
"Parece uma verdade elementar que a pedagogia há de repousar sobre o conhecimento da criança, do mesmo modo que a horticultura repousa sobre o conhecimento das plantas. E sem erro, é algo ignorado pela maioria dos pedagogos e por quase todas as autoridades escolares.” (CLAPAREDE apud ZILIO, 1993:10).
}

A autonomia também acaba em alguns casos sendo defendida enquanto teoria, mas no decorrer do trabalho o caminho vai em outra direção. Na tese "Psicopedagogia Institucional: a trajetória de seus atores-autores" é possível observar este aspecto. $\mathrm{Na}$ página 21 temos as seguintes afirmações:

\footnotetext{
"Cada escola desenvolverá uma filosofia, um fazer, uma ação específica... sem lugar para a reprodução... só a transformação, a criação terá espaço... Haverá sempre uma parte comum a todas as escolas (princípios gerais que regem a educação), o que possibilitará o êxito mediante a articulação com sua filosofia. Tal filosofia propõe transformar o já pensado, o autorizar a todos a pensar, compromissando-os com as idéias ações... " (NOFFS, 1996:21).
}

\footnotetext{
"Garantir a autonomia de pensamento através de um espaço onde as significações dos elementos do grupo possa ocorrer. Uma escuta, um olhar que se torne psicopedagógico no sentido de outorgar, consentir que as diferenças se apresentem. A autonomia (independente, livre, que se governa por leis próprias, que professa as próprias opiniões) pode levar a autonomia (mutilação espontânea que certos artrópodes, aranha, caranguejo praticam em si próprios, geralmente para escapar ao inimigo que os domina), na busca da heteronomia (subordinação ou sujeição à vontade eo outrem ou a uma lei exterior) grupal. Esta heteronomia deve ser vista não como submissão mas como parceria." (NOFFS, 1996)
} 
Essas frases poderiam dar a impressão que o trabalho caminharia em um sentido emancipatório, mas o problema é que a autora entende que todas essas conquistas são possíveis sem um questionamento ou alteração na estrutura social, pelo menos em nenhum momento isso é citado ou comentado. A seguir no trabalho, incoerentemente ela comenta que a autonomia deve ser evitada e deve ser tarefa do psicopedagogo ajudar nessa evitação: "Evitar a autonomia é tarefa grupal a ser constantemente estimulada pelo psicopedagogo” (NOFFS, 1996:73). Enfim, em sua definição de Psicopedagogia Institucional fica clara como a tendência que ela mantém é de entender a Psicopedagogia como área que procura resolver os problemas de aprendizagem a partir de situações pontuais, individuais (no caso a instituição) como não propiciadora de aprendizagem. Ela entende Psicopedagogia Institucional como a transformação da própria Pedagogia, devendo estudar as modalidades de ensino-aprendizagem desencadeadas e ou possibilitadas pela instituição escola, visando à prevenção e enfrentamento de conflitos (NOFFS, 1996). Tudo se resume em propiciar situações que possibilitem a aprendizagem. Não se fala como deve ser esta aprendizagem.

A Psicopedagogia traz uma inovação, aumenta a gama de opções para poder trabalhar com esses alunos que não são considerados normais, ou como muitas vezes é dito nesses trabalhos de uma maneira mais amena, alunos que são normais mas apresentam problemas ou distúrbios relacionados à aprendizagem, ou seja, só são anormais nesses aspectos, não deixando de normatizar portanto. A Psicopedagogia também aparece para diagnosticar a origem desses problemas, ou seja, se é orgânico, afetivo, pedagógico, social etc. "Bastava só um empenho maior do professor do ensino regular e o distúrbio de aprendizagem se resolveria. Era mais falha do professor do que do aluno" (MATIODA, 
1998:13). Neste caso bastaria um trabalho com estes professores por parte do psicopedagogo para o problema educacional se resolver.

Este tipo de visão em que o problema é o meio seja ele o professor, a escola ou outro, também aparece no trabalho "Psicopedagogia Inter-Ativa: ação psicopedagógica institucional baseada em uma convergência teórica": Para Lapierre, referencial utilizado pela autora, a criança possui as potencialidades positivas para o aprendizado bastando descobri-las e desenvolvê-las para o aluno aprender. O professor poderia ser uma dessas pessoas a descobrir tais potencialidades ou então o psicopedagogo. Ainda segundo o autor, devemos nos ater ao positivo e não ao negativo da criança:

\footnotetext{
"Na criança existem muitas potencialidades positivas $e$ devemos procurar descobri-las e desenvolvê-las para que não seja sempre fixado o que ela não sabe fazer. A vivência psicomotora não é isolada, cortada do pedagógico, é 'preciso oferecer à criança um meio pedagógico coerente, sem o que arriscamos acentuar sua inadaptação a uma escola que é, ela mesma inadaptada"'(MAMAN, 1997:45-46).
}

Ou seja, toda a solução está no meio, bastando encontrar um meio adequado que as potencialidades do aluno desenvolvem-se como plantas quando regadas. Os objetivos desse trabalho foram realizados em quatro níveis pragmáticos segundo a autora: preventivo, curativo, assistencial e teórico, mostrando novamente a tendência da "medicalização" na área da educação, com tentativas de prevenir e curar problemas de aprendizagem como epidemias.

O fracasso escolar é causado segundo a autora por problemas de origem familiar, emocional e cultural do aluno: 
ensino e adequar-se às normas de conduta exigidas como padrões disciplinares. Deveriam ser levados em conta aspectos fundamentais para o bom desempenho escolar como os culturais, psicológicos e a influência familiar” (MAMAN, 1997:03).

Especifica as causas das dificuldades de aprendizagem como sendo de natureza metodológica, estrutural, cultural, afetiva, social entre outras (MAMAN, 1997). Estes itens são apenas citados e não explicados ou definidos. Ela entende que em cada ocasião o problema de aprendizado pode ser causado por um fator diferente e não por uma sociedade que não possibilita a autonomia dos indivíduos, isso nem chega a ser questionado. Maman entende que os problemas de aprendizagem têm sua origem principalmente na má formação dos professores e que esta defasagem é específica desses professores dessa instituição em particular, e, portanto, a deficiência deveria ser corrigida pela instituição de trabalho do professor. Ela não entende que a má formação de professores é um problema geral e mais do que isso, não basta qualquer formação, mas uma formação que dê condições para o professor de fato poder entender o que é uma educação emancipatória, de maneira a poder atuar como modelo para seus alunos. A outra solução que apresenta para resolver os problemas de aprendizagem de uma maneira geral é reunir o que ela denomina de "tríade para o sucesso": profissional da Psicopedagogia, professor (escola) e família. Com estes três elementos reunidos o trabalho psicopedagógico terá êxito e por conseguinte, a Educação também terá. A autora procura o tempo todo justificar o facasso escolar apontando como causas setores particularizados sendo que o aspecto social fica em segundo plano, como mais uma das várias possibilidades particulares. Ela entende por aspectos sociais os seguintes:

\footnotetext{
"Relacionam-se às questões familiares e ao meio que cerca o sujeito, estando aqui incluídos a formação familiar, as condições econômicas, o acervo de sua cultura, os objetivos vistos pela família com relação à escolarização, as
} 
expectativas familiares com relação à aprendizagem do sujeito" (MAMAN,1997:19).

Ela enfatiza que a história tem uma importância fundamental no entendimento dos problemas de aprendizagem, mas ela se refere a história específica do aluno em particular e não da História da sociedade. Essa História não é mencionada e nem colocada como tendo importância. O trabalho que a autora desenvolve com os alunos da escola é mais no sentido da prática do que no da reflexão mantendo o padrão dos trabalhos psicopedagógicos. A maior parte das atividades propostas consiste em construir alguma coisa concreta: loja, posto de gasolina, fazenda, prédio etc. Ou então jogos competitivos com regras como torneio de dominó, memória etc. A atividade mais reflexiva que ela denomina de "livre-expressão" envolve o desenvolvimento de desenhos e histórias que, no entanto, não são analisados e trabalhados em maior profundidade. Ou seja, o trabalho que ela propõe se assemelha mais a um curso de artesanato, não desmerecendo essa prática, do que um trabalho formativo no sentido de fazer uma reflexão com as crianças sobre aspectos do mundo questionando-os ou de mostrar as enganações que estamos em contato todos os dias. Pelo contrário, ela acaba em muitas vezes colaborando para este tipo de pensamento, quando por exemplo é criado o "Prédio Feliz". A idéia de felicidade e harmonia que a nossa sociedade quer que acreditemos é enfatizada por ela quando não questiona o motivo do prédio ser feliz, ou se é possível ser feliz nas condições que a nossa atual sociedade se encontra atualmente com essa violência exagerada. Mesmo nas fotos dos alunos que ela não permite que vejamos suas fisionomias, ela desenha carinhas alegres por cima das deles, passando a idéia de que todos estão alegres e satisfeitos com o resultado do trabalho psicopedagógico. Ela fala da importância do trabalho cooperativo: será que este é possível? Ela prepara estes alunos para este tipo de trabalho? 
Parte do princípio que para haver aprendizagem basta um ambiente harmonioso, novamente se remetendo a teorias com bases "biologizantes".

Em relação ao aspecto social relacionado aos problemas da educação, todos esses autores citam essa possibilidade. Mas fica como uma dentre as possíveis e várias causas dos problemas educacionais e não como a principal. Para os autores, o aluno deve ser visto de "maneira global", levando em conta, portanto, aspectos orgânicos, afetivos, institucionais e sociais. Como foi dito, o social é apenas citado como um dos possíveis itens e nem sempre é definido, ficando subentendido o que quer dizer a palavra social. Na maior parte dos trabalhos o termo social é entendido como meio, que pode ser o familiar, por exemplo. Apenas em poucos trabalhos o termo foi definido. Este é um exemplo que ilustra bem a definição entendida para este termo "estão ligados às perspectivas da sociedade em que estão inseridos a família e escola" (MATIODA, 1998:13).

Em um dos trabalhos, em que há várias entrevistas com diversos autores da área, apenas uma das autoras entrevistadas comenta um pouco sobre a questão social e política na educação e da importância do desenvolvimento de um pensamento autônomo e que o psicopedagogo poderia contribuir com este item. Mas o que mais chama a atenção, é que quando a autora da dissertação faz sua análise sobre a entrevista dos autores, omite esse dado.

Uma outra postura que apareceu nos trabalhos foi a Psicopedagogia como prática clinica. Nesses trabalhos, a maneira de sanar os problemas de aprendizagem utilizada pelos autores foi a escuta psicanalítica e autoconhecimento. Alguns autores, como Lajonquiere (1992), fazem uma análise mais cuidadosa e profunda dessas questões, mas 
apontam a Psicanálise como solução para os problemas do fracasso escolar, embora sendo importante ressaltar que não temos controle dos resultados obtidos pela Psicanálise, uma vez que o inconsciente não é passível de controle e previsão. O problema geral dos trabalhos que defendem a Psicanálise como solução para os problemas de aprendizagem é fazer uma apropriação inadequada da teoria, entendendo a clínica psicanalítica de maneira medicalizada, aonde os pacientes dirigem-se a ela para terem um tratamento eficaz que sane a "epidemia" da aprendizagem, termo muito utilizado nos trabalhos e por autores de referência na área. E ainda, entendendo o Inconsciente psicanalítico como uma instância individual que reflete os problemas pessoais daquele paciente, podendo no máximo se estender à sua família ou escola ou meio.

Como podemos observar na tabela, apenas três trabalhos trouxeram a educação para emancipação não explicitada com este nome, mas enquanto idéia. Em um deles, "A invenção da adolescência no discurso psicopedagógico" não houve uma defesa de que a Psicopedagogia faz uso da questão social para análise de problemas na educação. Mas a contribuição que este trabalho teve em relação a um pensamento emancipatório foi o de criticar o discurso psicopedagógico em relação ao termo adolescência apontando sua fragilidade. Esse trabalho teve a preocupação em mobilizar uma conscientização sobre alguns conceitos pré-estabelecidos como únicos e que a identidade desses conceitos se dão em um processo histórico, em um contexto com amplitude. No caso desse trabalho, o termo adolescência no discurso psicopedagógico é apontado como se referindo a um "sujeito estéril, posto que monolítico e a-histórico, isto é, um sujeito portador de uma essência já conhecida, obstruindo assim a possibilidade de se chegar a novas conclusões" (CÉSAR, 1998:2). Portanto, essa autora é contrária a posições que apresentam dados apresentados de antemão como determinados, imutáveis e com tendência à reificação. 
“...discurso das ciências médicas e psicopedagógicas, que reproduzem um modelo normatizador e totalizante quando elaboram seus saberes sobre essa figura" (CÉSAR, 1998:5). Este trabalho, portanto, realiza uma crítica à cultura e aponta para a importância da análise dos discursos para poderem ser desconstruídos e terem a possibilidade, portanto, de transformação.

O outro trabalho considerado como abordando a psicopedagogia de acordo com a educação emancipatória foi “A atuação do profissional em Psicopedagogia e a formação do psicopedagogo em São Paulo no período de 1980 a 1990", aonde foi realizada uma reflexão teórica que caminhou em um sentido crítico. A autora fez um estudo da Psicopedagogia em São Paulo enquanto área de conhecimento e profissão de forma crítica como já dito anteriormente, mostrando que da maneira que a Psicopedagogia está estruturada e é pretendida está servindo a interesses coorporativistas, ou seja, apontou seus aspectos regressivos e que não contribuem para uma educação emancipatória. Uma das suas conclusões expressa bem a dinâmica do trabalho: A Psicopedagogia não é algo em si, mas pertence a uma dinâmica social específica que a produz (NASCIMENTO, 1993).

E o terceiro trabalho que caminhou no sentido da educação para emancipação foi "Epistemologia genética e prática psicopedagógica na escola: difusão da teoria e os expurgos da razão" que procurou buscar e analisar a difusão de idéias de Piaget sobre aprendizagem nos documentos e relatos sobre a prática psicopedagógica na escola desenvolvida na Secretaria Municipal da Educação de Porto Alegre em 1989-1993. Nesse trabalho foi escolhido analisar o referencial piagetiano porque foi o adotado pela Secretaria. Dessa análise a autora conclui que embora a Secretaria defenda um referencial, acaba por utilizar um ecletismo que aponta para incoerências e contradições nos 
pressupostos de seu discurso. Embora não fale diretamente sobre fins emancipatórios para a Psicopedagogia ou para a educação, consideramos este trabalho como voltado para a emancipação pois possui objetivos críticos e em alguns momentos ele realiza crítica da educação relacionada à sociedade em que vivemos.

TABELA 20b - Frequiência e proporção de dissertações e teses do programa de pós-graduação das faculdades de Psicologia que apresentam a psicopedagogia voltada para uma educação adaptativa ou emancipatória

\begin{tabular}{ccc}
\hline & frequência & proporção \\
Educação adaptativa & 05 & 0,8 \\
Educação emancipatória & 01 & 0,2 \\
Total & $\mathbf{0 6}$ & $\mathbf{0 1}$ \\
\hline
\end{tabular}

Pela tabela 20b podemos concluir que dos seis trabalhos analisados apenas um visa uma Psicopedagogia voltada para uma educação emancipatória. Os demais priorizam uma educação adaptativa.

Em um dos trabalhos, as palavras adaptação e emancipação não chegam a ser utilizadas e não há uma preocupação com esses termos no decorrer do trabalho. No entanto é possível inferir qual o sentido dado ao trabalho que é predominantemente o de "adaptar" uma vez que a tese apresenta como referencial teórico a Epistemologia Genética. Este referencial adota a adaptação como essencial para a sobrevivência do ser humano. Este termo é entendido da mesma maneira que as teorias biológicas entendem esta função: os mais fortes resistindo e os mais fracos sendo eliminados. Daí já é possível subentender que este tipo de trabalho defende uma educação predominantemente adaptativa e "biologizante". 
O único trabalho voltado para uma educação emancipatória, "Um estudo psicanalítico sobre a produção do conhecimento na criança psicótica", analisa criticamente ao se referir aos parâmetros de ação utilizados na psicose infantil quando esta não é analisada junto ao que ele nomeia de discurso do conhecimento ou quando é analisada nas intersecções com o discurso do conhecimento. "As práticas e intervenções que aqui são engendradas tomam, como parâmetros de ação, as idéias de inadaptação e inadequação social, o que envolve a necessidade de afastamento e exclusão..."(LIMA, 1998:139). Faz uma análise do tema de maneira crítica, procurando discutir de "qual lugar o homem pensa e discute o que nomeia e legitima como produção do conhecimento" (LIMA, 1998:07-08). Embora não utilize diretamente a teoria crítica em sua análise, utiliza idéias semelhantes a Adorno em relação ao conhecimento e sua evolução ao longo dos tempos. "Se antes as divindades e a ordem do divino a ocupavam, o Mundo das Idéias outorgou-se as suas prerrogativas, sem questionar ou interpelar os seus alicerces e fundamentos” (LIMA, 1998:09).

As demais dissertações e teses seguiram o esquema de aplicarem uma teoria seja ela a psicanálise, epistemologia genética, psicodrama e chegaram a conclusões a partir da aplicação direta dessas teorias sem um prévio questionamento se elas incluem uma análise crítica da sociedade de maneira a não reproduzirem a educação já instalada até então. Por exemplo, em "Oficina criativa e psicopedagogia", a autora utiliza frases como:

\footnotetext{
"Considero muito importante que o educador conheça muito bem a criança com quem trabalha, para que escolha situações em que possa levá-la a desenvolver uma autonomia de sua gestão mental". (ALLESSANDRINI, 1995:33). "A proposta da Psicopedagogia é trabalhar basicamente com as relações afetivas ocorridas entre o indivíduo e o conteúdo de aprendizagem, garantindo atitudes tais como: espontaneidade ao lidar com o pensamento, a perseverança no trabalho, a autonomia e autoconfiança, enquanto sujeito criativo $e$ transformador." (ALLESANDRINI, 1995:25). “A primeira imagem estava carregada de significado simbólico, mas ainda não era possível
} 
realçar a figura, dentro do pano de fundo que é o ser "a si mesmo"(ALLESSANDRINI, 1995:38).

Em nenhuma dessas frases e em várias outras foi questionado por exemplo se é possível na sociedade em que vivemos um indivíduo autônomo e autoconfiante, criativo e transformador. Ou ainda, o indivíduo transformador visa transformar o que? Se for a ele próprio, de qual maneira? De maneira a adaptar-se ao status quo? Ou se for para transformar a sociedade: transformá-la em qual sentido e visando qual direção? Ou ainda, é possível ser "si mesmo" nessa sociedade? E ainda mais uma vez vemos a aprendizagem sendo entendida como critério de saúde ou doença, retomando novamente a tendência à medicalização na Psicopedagogia e demais áreas do conhecimento relacionadas a Educação. "A Psicopedagogia propõe uma compreensão dessa questão, e minha busca tem-se direcionado diante da necessidade de encontrar novas formas de trabalhar o problema, para que aquele que o vive possa reestruturar sua forma de ser, fazer $e$ aprender, em uma dinâmica saudável do ser aprendiz” (ALLESSANDRINI, 1995:51).

O mesmo ocorre com as demais dissertações e teses como em "Psicodrama e construtivismo como uma psicopedagogia: estudos com crianças e adolescentes" que utiliza frases como: "Nesse sentido, os elos de autoridade e de respeito unilateral, característico das relações de autonomia, em que a cooperação pode ser identificada pelos elos de igualdade e respeito mútuo, produtos da reciprocidade" (WECHSLER,1994:22) Não é questionado em nenhum momento se é possível de fato na sociedade em que vivemos sermos iguais em direitos e não em normas. Outra idéia constante nesse tipo de pensamento é a de progresso: atingir uma meta é uma questão de construção e de etapas a serem seguidas para se atingir um alvo. Estas etapas se apresentam linearmente, ou seja, é uma questão de tempo e de superação da fase anterior 
que é possível se atingir o progresso: "Se concebemos a socialização, caminho para tornar a criança apta a cooperação (operar junto com), como um dos aspectos do progresso rumo à descentração..." (WECHSLER,1994:25). Socialização aqui mais uma vez entendida como meio estimulante, podendo ser a família que forneça condições estímulos - para se atingir tal meta. E finalizando, a técnica, a prática é vista como resolução para todos os problemas educacionais, mais uma vez distanciando-se de uma educação emancipatória. "inversão de papel como técnica de ensino e aprendizagem" (WECHSLER,1994:13). "Parece que o pressuposto para o ensino e aprendizagem é ensinar fazendo”. (WECHSLER,1994:14). Não quero dizer com estas observações que a técnica e a prática não sejam importantes para a educação, mas a utilização delas sem uma reflexão, ou seja cindidas é entendido como problemático sim.

Uma dissertação, "Leitura e retardamento mental: estudos com o "lendo e escrevendo", além de fazer aplicação direta da teoria, utilizou-se de testes de prontidão para alfabetização e viso-motores de maneira a classificar as crianças consideradas retardadas mentais em relação a sua capacidade de leitura e escrita. Em nenhum momento foram questionados tais instrumentos de medida. Eles funcionaram como critério de avaliação dessas crianças e para uma posterior adaptação de técnicas para atender essas crianças consideradas diferentes das demais por suas condições econômicas desfavoráveis. É mais uma vez o aparecimento da teoria da carência cultural.

TABELA 20c - Frequiência e proporção de dissertações e teses do programa de pós-graduação das faculdades de Educação que apresentam a psicopedagogia voltada para uma educação adaptativa ou emancipatória

frequência proporção

Educação adaptativa $\quad 03 \quad 1,0$

Educação emancipatória 
Em todos os trabalhos vemos uma Psicopedagogia voltada para a adaptação. Uma delas utilizando a aplicação direta de conceitos da teoria piagetiana e na outra, a defesa da psicanálise como técnica psicopedagógica. Na terceira delas, voltada mais para a Lingüística há uma ênfase na importância do prazer na aprendizagem. Cita diversas vezes palavras como alegria, prazer, felicidade, etc. Fala rapidamente sobre a importância da crítica na educação, mas o ponto chave da sua defesa em relação ao aprendizado é o prazer, que deve ser uma obrigação da escola proporcionar aos alunos. Essa defesa da aprendizagem prazerosa é relacionada com a aprendizagem a partir do afetivo, considerando não só o cognitivo, mas o emocional da mesma forma que, por exemplo, na obra "Inteligência emocional” (GOLEMAN, 1995). Enfim, faz uma cisão entre aprendizagem cognitiva e emocional, fazendo uma defesa da inteligência emocional e relacionada ao prazer na aprendizagem. Vale lembrar mais uma vez que entender que a criança deva aprender só a partir de situações prazerosas é menosprezar a capacidade da criança em aprender em situações cotidianas, onde o erro e a frustração não podem ser abolidos. 
Considerações Finais 


\section{Considerações Finais}

Este trabalho de pesquisa teve como objetivos verificar uma parcela da produção científica no Brasil em um período de 20 anos, entre os anos de 1981 e 2001, sobre o tema Psicopedagogia, a partir da análise de dissertações e teses. Essa produção foi caracterizada segundo ano de publicação, local de publicação, objetivos dos trabalhos, tipos de pesquisa, referenciais teóricos ou autores utilizados, conclusões e a concepção de Psicopedagogia entendida nestas obras.

A Psicopedagogia de uma maneira geral no período estudado (1981-2001) é considerada uma estratégia, área ou prática destinada a entender, prevenir, tratar $e$ ajudar pessoas com problemas de aprendizagem ou ainda entender, prevenir e tratar os problemas de aprendizagem. Esses últimos entendidos como determinados por aspectos orgânicos, cognitivos, afetivos e sociais. Surge com o objetivo portanto de resolver os problemas de aprendizagem e do fracasso escolar, problemas que as demais ciências como a Psicologia e a Pedagogia não conseguiram resolver ou minimizar até então. Para isso procuram oferecer um serviço especializado e direcionado com modalidades clínica e institucional repetindo na maior parte das vezes os erros cometidos pela Psicologia do século passado: naturalização do indivíduo, reafirmação do psicologismo - "redução da explicação de fenômenos sociais e políticos complexos e objetivos à esfera da subjetividade, das vontades, dos interesses e das limitações individuais" (SASS, 2003:1368) - e do "clinicalismo" - tratamento de problemas de ordem social no âmbito da clínica individual ou grupal procurando adaptar esses indivíduos às situações adversas (SASS, 2003) - tão presentes na Psicologia aplicada à educação do século passado e que atualmente os profissionais psicólogos estão 
procurando se desvencilhar. Vale lembrar que apenas citar o termo "social" ou entendê-lo como "meio" sinônimo de família ou instituição pontual, ou ainda, como falta de estimulação no sentido interacionista do termo, ou ainda entendê-lo como uma dentre várias possibilidades que só poderá ser afirmada diante de um diagnóstico prévio, no sentido médico herdado do termo, ou seja, em alguns casos o social influencia e em outros não influencia, não é suficiente para transpor as soluções oferecidas pela Psicologia e que não obtiveram êxito.

Ainda em relação às concepções, na década de 80 , apenas essa tendência apresentada acima se manteve. Vale lembrar que essa concepção na maior parte das vezes, entendia a Psicopedagogia de maneira adjetivada principalmente por parte de profissionais que decidiam fazer Pós-graduação nas faculdades de Psicologia, ou seja, indicando a união entre duas áreas de conhecimento: a Pedagogia e a Psicologia. Mas a partir da década de 90, essa concepção precisou ser aprimorada, pois não era suficiente para designar a Psicopedagogia como uma área independente de outras - ciência autônoma - como alguns autores a denominam, muitas vezes se confundindo com a Psicologia Escolar, Psicologia da Aprendizagem, Psicologia da Educação etc. A década de 90 teve a principal preocupação em dar uma identidade para a Psicopedagogia, tentando oferecer a ela uma conotação substantiva, possibilitando uma diferenciação das demais áreas, tendência que ainda ocorre nos anos 2000 e 2001. Esta preocupação em dar à Psicopedagogia um caráter autônomo está relacionada com a intenção de torná-la profissão, tema que não fez parte dos objetivos desse trabalho de pesquisa.

A presença predominante de referenciais teóricos que desconsideram os fatores objetivos na educação como a Epistemologia Genética ou de referenciais que 
incluem os fatores objetivos, mas que são apropriados de maneira distorcida, desconsiderando-os foi uma constante durante esses trabalhos nesse período analisado, havendo poucas exceções. Lembrando, a Psicologia tem como objeto de estudo o indivíduo, privilegiando assim os aspectos subjetivos em seus estudos referentes à educação. Mas, no entanto, ao fazer isso a Psicologia exclui a contradição existente entre indivíduo e sociedade convertendo-se em ideologia. E a Psicopedagogia repetindo esse comportamento também se torna ideológica.

A tendência ao tipo de pesquisa empírica ilustra a adaptação da Psicopedagogia à sociedade administrada, cuja prática, eficiência, utilidade, controle e previsibilidade são as únicas formas aceitas. O "saber fazer" aparece como prioridade em relação ao "fazer saber" e toda reflexão, conscientização (no sentido que Adorno entende a conscientização como produtora de uma consciência verdadeira).

O uso de diversos autores na maior parte das vezes com pensamentos contraditórios nessas dissertações e teses sem uma respectiva continuidade no decorrer das pesquisas é o reflexo da pseudoformação que é uma realidade no nosso contexto educacional seja no Ensino Fundamental, Ensino Superior e Pós-graduação. No contexto educacional atual o importante é mostrar "quantidade" de informação não interessando qual sua procedência e se há uma reflexão sobre a mesma, tudo para encobrir a insegurança provocada nos indivíduos causada pela mesma e para reafirmar a heteronomia. 
A maior parte das conclusões dessas dissertações e teses apontando para a reafirmação do discurso psicopedagógico hegemônico reflete a heteronomia presente na sociedade administrada. Nela as respostas e conclusões dos indivíduos já são conhecidas a priori, não sobrando espaço para a reflexão crítica e para a superação de problemas. A não superação dos problemas causa a sensação constante de fracasso que convertida em agressividade caminha em direção oposta do objetivo principal da educação segundo Adorno - eliminação da barbárie. Por isso é de extrema importância quando se pensa em Educação considerar não apenas a Educação Básica ou aquela que é dada às crianças, mas aos adultos também, pois da maneira que ela está instalada (heteronomia) é uma constante geradora de barbárie, justamente aquilo que Adorno não considera como objetivo educacional e condição para emancipação.

Retomando o que foi exposto durante o trabalho e no início dessas considerações finais, a Psicopedagogia ou as dissertações e teses analisadas tendem a se converter em ideologia, reafirmando uma educação adaptativa, voltada para a heteronomia, ou seja, adaptação voltada para fins regressivos, contrária àquilo que Adorno entende como adaptação como patamar necessário para a emancipação, como transmissão refletida dos legados culturais herdados.

Voltando às perguntas que deram suporte a essa pesquisa e tentando respondê-las, entendo que a Psicopedagogia atual procurando dar mais atenção à maneira individual de cada um aprender e lidar com o conhecimento não é suficiente para garantir a emancipação. Pelo contrário, este procedimento deu margem a entender e lidar com os problemas de aprendizagem de maneira pontual, incentivando ainda mais o atendimento de sujeitos em clínicas e instituições, ou seja, fazendo prevalecer 
os aspectos subjetivos e desconsiderando os objetivos. Embora teoricamente haja um discurso preocupado com a autonomia dos indivíduos e com soluções que busquem uma formação adequada, na prática isto não ocorre justamente pela falta de reflexão sobre um arsenal teórico já utilizado durante mais de um século por outras áreas do conhecimento e que reverteram em aumento do fracasso escolar e de uma educação adaptativa. A Psicopedagogia acaba por repetir esse padrão. A melhora dessas condições só se dará a partir da auto-reflexão de seu discurso, podendo aprimorá-lo no sentido de especificar melhor o que entendem por exemplo, por educação e formação de maneira a não repetir os mesmos erros já cometidos. Alguns poderiam dizer que a Psicopedagogia tem um discurso próprio e com diferenças em relação a outras áreas do conhecimento: realmente há algumas diferenças, mas isso não modifica o fato de não estarem abordando o que de fato a educação exige. Esse discurso também muitas vezes aparece desarticulado com a prática o que mostra a insistência desenfreada de acreditar que apenas pela ação sem reflexão será possível um avanço na área da educação. Existem poucos trabalhos preocupados com essa investigação e reflexão do discurso psicopedagógico o que pode revelar talvez um começo tímido desse novo processo. Concluindo, a Psicopedagogia de uma maneira geral não colabora para a educação contra a barbárie para uma educação emancipatória.

Para finalizar, vale mais uma vez lembrar que os problemas educacionais devem ser resolvidos inicialmente a partir de propostas envolvendo questões de conscientização política e formação do que técnicas e profissionais - priorizando o ambiente escolar ao invés da clínica e do consultório, de maneira a evitar que as pessoas tenham que pagar por aquilo que não recebem ou recebem de forma deficiente e que é um direito. Essa conclusão não vale apenas para a Psicopedagogia, mas para a 
Psicologia, Pedagogia e qualquer outra área interessada em solucionar o fracasso escolar. 


\section{Referências Bibliográficas}

ADORNO, T. W. Educação e emancipação. $2^{\mathrm{a}}$ ed., São Paulo: Paz e Terra, 2000.

. Teoria da semicultura in: Educação \& Sociedade, ano XVII, n56, dezembro/96, p.388-411.

ANDRADE, M. S. de A práxis e a produção de conhecimento em Psicopedagogia. In: Andrade \& Capovilla (organizadoras), A produção do conhecimento: métodos e técnicas de pesquisa em Psicopedagogia. São Paulo: Memnon, 2002.

ARANHA, M. L. A. História da Educação. São Paulo: Moderna, 1989.

ARGENTI, P. W. \& ESCOTT, C. M. A formação em Psicopedagogia nas abordagens clínica e institucional: uma construção teórico- prática. Novo Hamburgo: Feevale, 2001.

BISSERET, N. A ideologia das aptidões naturais, in J.C.G. Duran (org.) Educação $e$ Hegemonia de Classe. Rio de Janeiro, Zahar, 1979, p.30-67.

BOSSA, N. A. A Psicopedagogia no Brasil: contribuições a partir da prática. $2^{\mathrm{a}}$ ed., Porto Alegre: Artmed, 2000.

CAMBI, F. História da Pedagogia. trad. Álvaro Lorencini. São Paulo, Editora Unesp, 1999.

CAMPOS, M. M. Anped 99 teses, dissertações e artigos de periódicos. $3^{\text {a }}$ ed., São Paulo: ANPED, 1999.

Conselho Nacional e Nato do Biênio. Código de ética da ABPp. São Paulo, 1996. 
CROCHIK, J.L. A (im)possibilidade da psicologia política. In M.A., Azevedo e M.S.S, Menin (orgs.) Psicologia e política: reflexões sobre possibilidades e dificuldades deste encontro. São Paulo: Cortez; Fapesp, 1995, 13-56p.

Preconceito: indivíduo e cultura. São Paulo: Robe editorial, 1997.

FASCE, J. "Prólogo" a VISCA. In: Clínica Psicopedagógica - epistemologia convergente. Porto Alegre: Artes Médicas, 1987.

FERNÁNDEZ, A. A inteligência aprisionada: abordagem psicopedagógica clínica da criança e sua família. Porto Alegre: Artes Médicas, 1991.

FERREIRA, A.B.H. Dicionário Aurélio básico da língua portuguesa. Rio de Janeiro: Nova Fronteira, 1995.

FREUD, S. Obras Completas. Edição Standard Brasileira, Rio de Janeiro: Imago, 1974.

GOLEMAN, D. Inteligência emocional:a teoria revolucionária que define o que é ser inteligente. 36 ed. Rio de Janeiro: Objetiva, 1995.

GOULD, S. J. A falsa medida do homem. $2^{\text {a }}$ ed., São Paulo: Martins Fontes, 1999.

HOBSBAWM, E. Era dos extremos: o breve século XX: 1914-1991. trad. Marcos Santarrita, São Paulo: Companhia das Letras, 1995.

HORKHEIMER, M. \& ADORNO, T. W. Dialética do esclarecimento: fragmentos filosóficos. Rio de Janeiro: Jorge Zahar Editor, 1985, 254p.

. Sociológica. Madrid: Taurus, 1971, p.233-267. 
JUNG, C.G. Tipos psicológicos. v.6 Obras completas de Carl Gustav Jung, $8^{\mathrm{a}}$ ed., Petrópolis: Vozes, 1991.

MACEDO, L. de "Prefácio" a Scoz et alii. In: Psicopedagogia - contextualização, formação e atuação profissional. Porto Alegre: Artes Médicas, 1991.

MALANGA, E. B. A metodologia como episteme e a pesquisa em Psicopedagogia. In: Andrade \& Capovilla (organizadoras), A produção do conhecimento: métodos e técnicas de pesquisa em Psicopedagogia. São Paulo: Memnon, 2002.

MASINI, E.F.S. Ação psicopedagógica: II Ciclo de estudos de Psicopedagogia Mackenzie, São Paulo: Memnon: Mackenzie, 2000.

MERY, J. Pedagogia curativa escolar e psicanálise. Porto Alegre: Artes Médicas, 1985.

MOYSÉS, M.A.A. \& COLLARES, C.A.L. A história não contada dos distúrbios de aprendizagem. In Caderno Cedes, $\mathrm{n}^{\circ}$ 28, 1992, p.31-47.

PAIN, S. Diagnóstico e tratamento dos problemas de aprendizagem. $2^{a}$ ed., Porto Alegre: Artes Médicas, 1986.

Psicopedagogia operativa: tratamento educativo da deficiência mental. Porto Alegre: Artes Médicas, 1987.

PATTO, M.H.S. A questão da Psicopedagogia como profissão. In Ação psicopedagógica: II Ciclo de estudos de Psicopedagogia Mackenzie, São Paulo, julho de 2000 - Elcie Masini (org.). São Paulo: Memnon: Mackenzie, 2000, 46-50p.

Prefácio. In M.A., Azevedo e M.S.S, Menin (orgs.) Psicologia e política: reflexões sobre possibilidades e dificuldades deste encontro. São Paulo: Cortez; Fapesp, 1995, 09-12p.

A produção do fracasso escolar: histórias de submissão e rebeldia. São Paulo: Casa do Psicólogo, 2000. 
PUCCI, B. et ali. Adorno: o poder educativo do pensamento crítico. Rio de Janeiro: Vozes, 1999, 192p.

RUBINSTEIN, E. R. $O$ estilo de aprendizagem e a queixa escolar: entre o saber $e$ o conhecer. São Paulo: Casa do Psicólogo, 2003.

SAMPAIO, M.L.C.A. Em busca de um sentido para a experiência escolar: história de crianças em escolas de elite. Dissertação apresentada ao Programa de Pós-graduação da Faculdade de Educação da Universidade de São Paulo. São Paulo, 2003.

SARGO, C. et alii. A práxis psicopedagógica brasileira. São Paulo: ABPp, 1994.

SASS, O. Educação e Psicologia social: uma perspectiva crítica. In: São Paulo em Perspectiva. 2000, nº14, 57-64.

Problemas da Educação: o caso da psicopedagogia. In Educação \& Sociedade: revista de ciência da educação. Vol.24 (dezembro 2003), n.85, São Paulo: Cedes, 2003.

SAVIANI, D. Escola e democracia: polêmicas do nosso tempo. $32^{\mathrm{a}}$ ed., Campinas: Autores Associados, 1999.

SCOZ, B. J. L. A identidade do psicopedagogo: formação e atuação profissional. In: SCOZ et alii, Psicopedagogia - contextualização, formação e atuação profissional. Porto Alegre: Artes Médicas, 1991.

SCOZ, B. J. L. et alii. Psicopedagogia: o caráter interdisciplinar na formação e atuação profissional. Porto Alegre: Artes Médicas, 1987.

SOUZA, J. C. de Apontamentos para uma abordagem dialética na Psicopedagogia. In: Andrade \& Capovilla (organizadoras), A produção do conhecimento: métodos e técnicas de pesquisa em Psicopedagogia. São Paulo: Memnon, 2002. 
SOUZA, M. P. A queixa escolar e o predomínio de uma visão de mundo, in Adriana M. Machado \& Marilene P. R. de Souza (orgs.) Psicologia escolar: em busca de novos rumos. São Paulo, Casa do Psicólogo, 1997, p.17-33.

SZTERLING, S. Diálogo entre a psicanálise $e$ a psicopedagogia: sobre a (im)possibilidade de aprender. . Dissertação apresentada ao Programa de Pósgraduação da Faculdade de Educação da Universidade de São Paulo. São Paulo, 2000.

VISCA, J. Psicopedagogia - novas contribuições. Rio de Janeiro: Nova Fronteira, 1991.

Referências bibliográficas das dissertações e teses utilizadas como material de análise nesta obra

Allessandrini, C. D. Oficina criativa e psicopedagogia. Dissertação (Mestrado) - Instituto de Psicologia da Universidade de São Paulo, São Paulo, 1995.

Barone, L. M. C. De ler o desejo, ao desejo de ler: uma leitura do olhar do psicopedagogo. Tese (Doutorado) - Instituto de Psicologia da Universidade de São Paulo, São Paulo, 1990.

Becker, M. L. R. Epistemologia genética e prática psicopedagógica na escola: difusão da teoria e os expurgos da razão. Tese (Doutorado) - Universidade Federal do Rio Grande do Sul, Porto Alegre, 1998.

Bossa, N. A. L. A psicopedagogia no Brasil: contribuições a partir da prática. Dissertação (Mestrado) - Pontifícia Universidade Católica São Paulo, São Paulo, 1993.

Castro, H. S. de. Efeitos de atividades no domínio espacial sobre a superação do egocentrismo infantil: uma experiência psicopedagógica preventiva. Dissertação (Mestrado) - Pontifícia Universidade Católica Rio de Janeiro, Rio de Janeiro, 1984. 
César, M. R. A. A invenção da adolescência no discurso psicopedagógico. Dissertação (Mestrado) - Unicamp, Campinas, 1998.

Dorneles, B. V. Esquemas da construção numérica elementar da escrita alfabética em crianças de cinco e seis anos. Tese (Doutorado) - Instituto de Psicologia da Universidade de São Paulo, São Paulo, 1996.

Ferreira, W. G. N. Clínica psicopedagógica do trabalhador-professor. Dissertação (Mestrado) - Universidade Federal Fluminense, Rio de Janeiro, 1989.

Gil, B. D. Letras de musica popular:vocabulário, campos conceituais e campos léxicosemânticos como instrumento de ensino de língua. Dissertação (Mestrado) - Faculdade de Educação da Universidade de São Paulo, São Paulo, 1997.

Granato, I. A. D. T. A orientação psicopedagógica, um espaço a ser conquistado: a realidade de escolas públicas de Piracicaba. Dissertação (Mestrado) - Universidade Metodista de Piracicaba, Piracicaba, 1994.

Lajonquiere, L. de. De Piaget a Freud: notas para repensar o erro nas aprendizagens, a (psico) pedagogia entre o conhecimento e o saber. Tese (Doutorado) - Unicamp, Campinas, 1992.

Lima, L. A. G. Um estudo psicanalítico sobre a produção do conhecimento na criança psicótica. Dissertação (Mestrado) - Instituto de Psicologia da Universidade de São Paulo, São Paulo, 1998.

Maman, C. F. de. Psicopedagogia interativa: ação psicopedagógica institucional baseada em uma convergência teórica. Dissertação (Mestrado) - Faculdade de Educação da Universidade de São Paulo, São Paulo, 1997.

Matioda, V. L. Sugestões para uma proposta psicopedagógica da educação básica no ensino fundamental. Dissertação (Mestrado) - Pontifícia Universidade Católica Rio Grande do Sul, Porto Alegre, 1998. 
Mello, G. V. de. A proposta psicopedagógica é viável?. Dissertação (Mestrado) - Unesp Marília, Marília, 1996.

Moraes, H. N. de. Opiniões de alunos de um curso de pós-graduação especialização em psicopedagogia quanto as suas expectativas em relação ao curso e os conhecimentos construídos durante o curso a respeito de dificuldades de aprendizagem. Dissertação (Mestrado) - Pontifícia Universidade Católica Rio Grande do Sul, Porto Alegre, 1995.

Nascimento, M. da G. A atuação do profissional em psicopedagogia e a formação do psicopedagogo em São Paulo no período de 1980 a 1990. Dissertação (Mestrado) Faculdade de Educação da Universidade de São Paulo, São Paulo, 1993.

Nicola, I. P. Situação existencial da pessoa idosa de classe média: um estudo descritivo-interpretativo e uma proposta de aconselhamento psicopedagógico. Dissertação (Mestrado) - Pontifícia Universidade Católica Rio Grande do Sul, Porto Alegre, 1988.

Noffs, N. A. Psicopedagogia institucional: a trajetória de seus atores-autores. Tese (Doutorado) - Faculdade de Educação da Universidade de São Paulo, São Paulo, 1996.

Rangel, A. P. F. N. Leitura e retardamento mental: estudos com o lendo e escrevendo. Dissertação (Mestrado) - Instituto de Psicologia da Universidade de São Paulo, São Paulo, 1986.

Sgarbossa, S. L. Z. Atendimento psicopedagógico e as dificuldades de aprendizagem. Dissertação (Mestrado) - Pontifícia Universidade Católica Rio Grande do Sul, Porto Alegre, 1998.

Silva, M. C. A. Em busca de uma fundamentação teórica para a psicopedagogia. Dissertação (Mestrado) - Pontifícia Universidade Católica Rio de Janeiro, Rio de Janeiro, 1989.

Szpiczkowisk, A. A sensibilização pela comunicação não-verbal e por situações lúdicas: uma proposta metodológica para o trabalho psicopedagógico baseado numa 
abordagem humanista de educação. Dissertação (Mestrado) - Pontifícia Universidade Católica São Paulo, São Paulo, 1984.

Szterling, S. Diálogo entre a psicanálise e a psicopedagogia: sobre a (im)possibilidade de aprender. Dissertação (Mestrado) - Faculdade de Educação da Universidade de São Paulo, São Paulo, 2000.

Teixeira, M. B. Toda criança é capaz de aprender uma intervenção psicopedagógica com crianças multirrepetentes. Dissertação (Mestrado) - Pontifícia Universidade Católica São Paulo, São Paulo, 1996.

Wechsler, M. P. da F. Psicodrama e construtivismo como uma psicopedagogia: estudos com crianças e adolescentes. Tese (Doutorado) - Instituto de Psicologia da Universidade de São Paulo, São Paulo, 1994.

Zilio, M. P. Psicopedagogia: um perfil profissional em conflito. Dissertação (Mestrado) - Pontifícia Universidade Católica Rio Grande do Sul, Porto Alegre, 1993.

Zugueib Neto, J. Estratégias psicopedagógicas no atendimento ao jovem portador de distúrbios emocionais severos. Dissertação (Mestrado) - Universidade Federal do Paraná, Curitiba, 1993. 
Anexos 
Anexo 1 


\section{Registros}

\section{A sensibilização pela comunicação não verbal e por situações lúdicas: uma proposta metodológica para o trabalho psicopedagógico baseado numa abordagem humanista de educação (ANPED PUC SP - mestrado - 1984)}

1) Concepções - a psicopedagogia consiste numa reflexão e atuação sobre os problemas de aprendizagem que ocorrem com os educadores e educandos.

2) Objetivos - apresentar uma metodologia psicopedagógica e mostrar a viabilidade de sua aplicação.

3) Tipo de pesquisa - empírica.

4) Autores ou Referencial teórico - humanismo de Rogers, Rich, De La Puente e gestalt terapia.

5) Conclusões - É possível aplicar esta metodologia psicopedagógica obtendo-se resultados satisfatórios como recuperação de distúrbios de aprendizagem aliados ao desenvolvimento das suas capacidades de percepção, atenção, raciocínio lógico dedutivo, organização espaço temporal e relacionamento interpessoal. 
2. Efeitos de atividades no domínio espacial sobre a superação do egocentrismo infantil: uma experiência psicopedagógica preventiva (PUC RJ ANPED - mestrado - 1984)

1) Concepções - área que estuda a aprendizagem sob a tríplice ótica cognitiva, afetiva e social.

2) Objetivos - verificar se atividades de "domínio espacial" produzem efeitos na superação do egocentrismo infantil.

3) Tipo de pesquisa - empírica.

4) Autores ou Referencial teórico - Jorge Visca e Jean Piaget.

5) Conclusões - as atividades de "domínio espacial" produzem efeitos na superação do egocentrismo infantil e a escola deve fazer alterações curriculares, metodológicas e na formação dos professores. 
3. Situação existencial da pessoa idosa de classe média: um estudo descritivo - interpretativo e uma proposta de aconselhamento psico-pedagógico (ANPED mestrado 1988)

1) Concepções - aconselhamento psico-pedagógico: proposta de ação voltada para a solução de problemas.

2) Objetivos - identificar a situação existencial do idoso de classe média, avaliar com o idoso o atendimento de suas necessidades e respeito e elaborar um plano psicopedagógico para o idoso.

3) Tipo de pesquisa - empírica com uso de entrevista.

4) Autores ou Referencial teórico - Hoose et Worth Vaillant.

5) Conclusões - os idosos entrevistados não apresentam problemas de alimentação, mas apresentam problemas de saúde. O aspecto social tem influência sobre a velhice. Os idosos consideram a assistência familiar como prioritária. 
4. “Clínica psicopedagógica do trabalhador-professor” (Ferreira, W.G.N. 1989) - não disponível para leitura.

5. Em busca de uma fundamentação teórica para a psicopedagogia (PUC RJ ANPED - mestrado - 1989)

1) Concepções - cita alguns mas não adota nenhum deles, procura analisá-los.

2) Objetivos - buscar uma fundamentação teórica para a psicopedagogia.

3) Tipo de pesquisa - teórica.

4) Autores ou Referencial teórico - não adota.

5) Conclusões - psicopedagogia com falta de nitidez conceitual e em estado de pré-saber. 
6. "A psicopedagogia no Brasil: contribuições a partir da prática" (Bossa, N.A.L. - ANPED PUC-SP - 1993).

1) Concepções - psicopedagogia como contribuição na busca de soluções para o problema de aprendizagem; prática, campo de investigação do ato de aprender.

2) Objetivos - estruturar a psicopedagogia como campo de conhecimento prático, docente e clínico.

3) Tipo de pesquisa - teórica.

4) Autores ou Referencial teórico - Sarah Pain, Alicia Fernandez.

5) Conclusões - psicopedagogia como termo híbrido, independente e de natureza interdisciplinar fundada na prática; mais evoluída na Argentina do que no Brasil pelo fato de poderem aplicar testes; os cursos não cumprem as idéias da psicopedagogia principalmente em relação a afetividade, a psicopedagogia considera um sujeito total. 


\section{A atuação do profissional em Psicopedagogia e a formação do psicopedagogo em São Paulo no período de 1980 a 1990 (FE - ANPED - mestrado -}

1) Concepções - Psicopedagogia com interesses nas dificuldades de aprendizagem, processos de ensino, atividades integradoras, incluindo aspectos técnicos e afetivos. Importante diferenciar psicopedagogia enquanto adjetivo e enquanto substantivo - “A Psicopedagogia é subsumida pelo caráter adjetivo do termo psicopedagógico que já apontamos e que está na base da experiência de cada um. (...) intuem que deve existir algo de novo que caracteriza a Psicopedagogia e a diferencia do "seu psicopedagógico vivido”,". (NASCIMENTO, 1992:38) Faz um apanhado geral de várias concepções e chega a conclusão que é uma área que trabalha em atender indivíduos em condições normais ou patológica e que apresenta ou não dificuldades para aprender em situações de ensino formais ou em situações cotidianas de maneira a criar condições para que o sujeito possa desenvolver sua autonomia e viver satisfatoriamente bem. A autora discorre muito sobre as concepções pois faz parte do objetivo do trabalho.

2) Objetivos - desenvolver uma reflexão sobre os dados coletados da atuação profissional em Psicopedagogia em São Paulo, no período de 1980 a 1990. Os aspectos analisados serão a formação do psicopedagogo e o objeto de trabalho do psicopedagogo, os meios, locais e relações de trabalho.

3) Tipo de pesquisa - reflexão teórica.

4) Autores ou Referencial teórico - os autores utilizados foram psicopedagogos entrevistados como Mônica Hoehne Mendes, coordenadores dos cursos de Psicopedagogia e estudiosos da área da educação e afins.

5) Conclusões - Psicopedagogia como campo de atuação naturalmente interdisciplinar e multidisciplinar; a atuação admite amplo leque de profissionais e um deles é o psicopedagogo, não constituindo ainda prerrogativa de um profissional legal e especificamente habilitado; não foi possível distinguir nos cursos as propostas psicopedagógicas das não psicopedagógicas sendo as diferenças apenas particularidades, 
chegando no máximo à "psicopedagogias"; não há concordância com o grau de identidade e indentificações entre o psicopedagogo e a Psicopedagogia; Psicopedagogia não é algo em si, mas pertence a uma dinâmica social específica que a produz.

8) “Estratégias psicopedagógicas no atendimento ao jovem portador de distúrbios emocionais graves” (Zugueib Neto, J. - 1993) - não disponível para leitura. 
9. Psicopedagogia: um perfil profissional em conflito (Zílio, M.P. - ANPED - 1993).

1) Concepções - a autora comenta a insuficiência de definição da área, então utiliza a definição apresentada pela Associação Brasileira de Psicopedagogia (Abpp): “A psicopedagogia é a área que estuda e lida com os processos de aprendizagem e duas dificuldades" (1990). Somente a ação psicopedagógica pode resgatar a saúde da criança e da escola. Psicopedagogia como campo de ação multi e interdisciplinar; uma ciência unitária, autônoma, integradora de disciplinas.

2) Objetivos - análise do perfil do psicopedagogo a partir do relato de profissionais da área em comparação com o perfil traçado pela Abpp.

3) Tipo de pesquisa - pesquisa de campo envolvendo entrevistas e análise de conteúdo.

4) Autores - não utilizou referencial teórico, mas entrevista diversos autores da área como Lino de Macedo

5) Conclusões - Psicopedagogia como uma área que possui uma visão holística do homem e que possui uma metodologia que permite a ele autoconhecimento, autoaceitação, disponibilidade de atender o outro, além de preencher uma falta entre a Psicologia e a Pedagogia. 
10. “A orientação psicopedagógica, um espaço a ser conquistado: a realidade das escolas públicas de Piracicaba” (Granato, I.A.D.T. - 1994). Não disponível para leitura

11. Opiniões de alunos de um curso de especialização em psicopedagogia, quanto às suas expectativas em relação ao curso e aos conhecimentos construídos a respeito de dificuldades de aprendizagem (Moraes, H.N. de - ANPED - 1995).

1) Concepções - Psicopedagogia como estratégia para entender crianças e adolescentes com dificuldades de aprendizagem, prevenir, repensar, recriar e reconstruir novas propostas metodológicas que levem em conta todos aspectos do aluno e ofereça conhecimentos mais adequados.

2) Objetivos - investigar a opinião de alunos do curso de pós graduação especialização em psicopedagogia sobre as aquisições de conhecimentos que foram proporcionadas pelo curso em relação às dificuldades de aprendizagem.

3) Tipo de pesquisa - empírica

4) Autores - Piaget, Vygotsky, Luria e Freud.

5) Conclusões - os alunos perceberam a importância da reflexão para compreender diversos fenômenos psicopedagógicos e para diferenciar o que seja uma aquisição de conhecimentos normal e o que seria dificuldades de aprendizagem ou déficit na aquisição de conhecimentos. 
12) “A proposta psicopedagógica é viável?” (Mello, G.V.de - 1996) - não disponível para leitura.

13. Psicopedagogia Inter-Ativa: ação psicopedagógica institucional baseada em uma convergência teórica (FE - ANPED - mestrado - 1997)

1) Concepções - Psicopedagogia como necessidade de se compreender o processo de aprendizagem.

2) Objetivos - contribuir com alternativas para uma ação psicopedagógica institucional frente às dificuldades de aprendizagem; proporcionar aos professores e profissionais da educação esclarecimentos e instrumentalização para os problemas encontrados no cotidiano da sala de aula interferentes no processo ensino-aprendizagem.

3) Tipo de pesquisa - pesquisa etnográfica - empírica.

4) Autores ou Referencial teórico - Epistemologia Convergente de Jorge Visca, Sócio-interacionismo de Vygotsky, Psicomotricidade Relacional de Lapierre e técnicas da Pedagogia de Freinet: Psicopedagogia Inter-ativa.

5) Conclusões - há muitas resistências a mudanças por parte do corpo docente das escolas; professores precisam de melhor formação e instrumentalização que deve ser proporcionado pela escola. 


\section{Sugestões para uma proposta psicopedagógica da Educação Básica no}

Ensino Fundamental (ANPED - 1998)

1) Concepções - Psicopedagogia como nova área, uma estratégia de ajuda que articula Psicologia e Pedagogia preenchendo um vazio entre ambas e que lida com a aprendizagem, propiciando condições para a sua ocorrência, acompanhando o processo do aluno para que este compreenda o que é ensinado e supere suas dificuldades.

2) Objetivos - elaborar uma sugestão de proposta psicopedagógica para assessorar os professores de alunos com distúrbios de aprendizagem pertencentes às séries iniciais do Ensino Fundamental.

3) Tipo de pesquisa - descritiva "procura conhecer e interpretar a realidade, sem nela interferir para modificá-la (RUDIO, 1991)” - empírica

4) Autores - Piaget, Freud, Ajuriaguerra, Pamplona, Coelho, Ferreiro, Freire, Valett, Frosting, Le Boulch, Condemarin, Feurstein, Ross, Demo, Johnson e Myklelrist, Kato, Pain, Weiss e outros.

5) Conclusões - são as causas dos distúrbios de aprendizagem segundo depoimentos das professoras são os fatores emocionais, orgânicos, sociais e pedagógicos. Como sugestão de proposta psicopedagógica recomenda-se trabalhar: conhecimento de direita e esquerda e lateralidade; orientação espacial e temporal; ritmo, imagem corporal; análise síntese visual e auditiva, habilidades visuais e auditivas específicas, percepção e discriminação de semelhanças e diferenças; constância de percepção de formas e tamanhos; percepção de figura-fundo; coordenação viso-motora; discriminação de sons e vocabulário. 


\section{Atendimento psicopedagógico e as dificuldades de aprendizagem (ANPED}

- mestrado 1998)

1) Concepções - área multiprofissional que integra ciências como Pedagogia, Psicologia, Fonoaudiologia, Neuropsicologia, Psicolingüística, Medicina, etc, tendo função curativa e preventiva nas áreas de aprendizagem escolar.

2) Objetivos - diagnosticar quais as dificuldades de aprendizagem apresentadas pelos alunos da $2^{\mathrm{a}}$ série do Ensino Fundamental das escolas multisseriadas de Ouro Verde.

3) Tipo de pesquisa - empírica - estudo de caso.

4) Autores ou Referencial teórico - a autora denomina multiprofissional incluindo autores como: Piaget, Walon, Erikson, Vygotsky, Freire, Bruner, Luria, Fonseca, Valett, Ausubel, Weiss, Macedo.

5) Conclusões - as dificuldades dos alunos são de cunho psicológico e social como a resistência da família, má avaliação anterior por parte da escola e falta de investimento financeiro na qualificação de professores e do psicopedagogo da rede municipal de ensino estudada. $\mathrm{O}$ atendimento psicopedagógico se mostrou eficaz àqueles que freqüentaram as sessões. 
1) Concepções - termo para unir Psicologia e Pedagogia.

2) Objetivos - investigar a constituição histórica da "adolescência" no discurso psicopedagógico apontando a sua fragilidade epistemológica constitutiva.

3) Tipo de pesquisa - teórica de abordagem histórica

4) Autores - Jurandir F. Costa, Margareth Mead, Michel Foucault.

5) Conclusões - o discurso psicopedagógico que fala sobre a adolescência a trata como se ela fosse um universal a-histórico e natural.

17. De Piaget a Freud: notas para repensar o erro nas aprendizagens: a (psico)pedagogia entre o conhecimento e o saber (ANPED - doutorado - 1992) 
1) Concepções - psicopedagogia como mecânica ortopédica que alimenta o discurso hegemônico da pedagogia (ciência dos meios e fins da educação) excluindo qualquer intermediação que não possa ser controlada e que acredita que a chave da aprendizagem está na lógica maturacionista do organismo.

2) Objetivos - conceituar as marchas e contramarchas que se sucedem nas aprendizagens, as vicissitudes (incluindo os erros) de um sujeito em aprendizagem.

3) Tipo de pesquisa - teórica.

4) Autores ou Referencial teórico - Freud/Lacan, Piaget.

5) Conclusões - a clínica psicopedagógica deve ser atravessada pela ética da psicanálise, já que nunca há uma independência e sim um entrelaçamento entre o Conhecimento e o Saber.

18. Psicopedagogia Institucional: a trajetória de seus atores-autores (FE ANPED -doutorado 1996) 
1) Concepções - Psicopedagogia estuda as modalidades de aprendizagem as quais devem ocorrer de forma natural e espontânea; procura detectar as causas pelas quais os indivíduos não aprendem ou estão desadaptados.

2) Objetivos - descrever, explicar e elaborar proposta alternativa para o entendimento de uma prática transformadora.

3) Tipo de pesquisa - pesquisa qualitativa - estudo de caso - empírica.

4) Autores ou Referencial teórico - psicodrama de Moreno e psicopedagogia de Alicia Fernandez.

5) Conclusões - Psicopedagogia institucional pode contribuir para processos reflexão-ação-reflexão; se articula com o pedagógico; seu olhar se condensa nas modalidades de aprendizagem; nova área que se delineia como alternativa inovadora; na Psicopedagogia institucional criar e manter vínculos sadios é essencial a partir da prevenção, devendo ser afastar de falsos educadores e psicopedagogos com discursos bonitos e se ater à prática, à vivência e a transformação do pedagógico a partir do trabalho coletivo.

19. Epistemologia genética e prática de psicopedagogia na escola: difusão da teoria e os expurgos da razão ( $A N P E D$ - doutorado - 1998) 
1) Concepções - não adota uma; analisa a existente na Secretaria da Educação de Porto Alegre.

2) Objetivos - buscar a difusão de idéias de Piaget sobre aprendizagem nos documentos e relatos sobre a prática psicopedagógica na escola desenvolvida na SMED de Porto Alegre em 1989-1993.

3) Tipo de pesquisa - teórica.

4) Autores ou Referencial teórico - Figueiredo, Figueira, Vasconcelos, ParratDayan.

5) Conclusões - a prática na Secretaria da Educação de Porto Alegre se desenvolveu numa proposta eclética sobressaindo a matriz romântica. Eles adotam como referencial teórico o construtivismo, psicanálise e a sócio-antropologia.

01. Leitura e retardamento mental: estudos com o "lendo e escrevendo" (IPUSP - mestrado - 1986)

1) Concepções - não cita, mas fica algo próximo a uma psicologia escolar clínica. 
2) Objetivos - envolve 4 pesquisas sobre psicologia do excepcional, leituraescrita e avaliação psicológica. Comparar a realização de crianças retardadas mentais em uma prova de prontidão e uma de percepção visomotora com o desempenho num material de ensino de leitura em nível e alfabetização.

3) Tipo de pesquisa - empírica.

4) Autores ou Referencial teórico - Witter, Copit e Poppovic.

5) Conclusões - existe um conteúdo verbal de cunho psicolingüístico a ser considerado no processo de alfabetização, o qual deve ser levado em conta na escolha do material instrucional a ser usado; crianças consideradas retardadas mentais alunas da APAE podem aprender a ler num ritmo próprio e com métodos especiais que não necessariamente são aqueles impostos pela elite cultural.

02. Oficina Criativa e Psicopedagogia (IPUSP - mestrado - 1995)

1) Concepções - psicopedagogia estuda o processo de aprendizagem a partir de uma contextualização teórico-prática que advém da pedagogia e da psicologia. 
2) Objetivos - demonstrar a eficiência do trabalho de Oficina Criativa dentro do contexto psicopedagógico.

3) Tipo de pesquisa - empírica.

4) Autores ou Referencial teórico - Psicologia Analítica de Jung e Construtivismo de Jean Piaget.

5) Conclusões - a Oficina Criativa ajuda experienciar a aprendizagem de forma a ampliá-la.

03. Um estudo psicanalítico sobre a produção do conhecimento na criança psicótica (IPUSP - mestrado - 1998)

1) Concepções - não diz. 
2) Objetivos - rever o conceito de conhecimento na obra de Freud para estabelecer seus desdobramentos no contexto da psicose infantil.

3) Tipo de pesquisa - teórica.

4) Autores ou Referencial teórico - psicanálise - Freud e Lacan.

5) Conclusões - há três eixos referenciais para a análise das relações entre psicose infantil e conhecimento: a produção do conhecimento na psicose infantil fora do discurso do conhecimento; produção do conhecimento na psicose infantil nas intersecções com o discurso do conhecimento; produção do conhecimento na psicose infantil no discurso do conhecimento.

04. De ler o desejo ao desejo de ler (IPUSP - doutorado - 1990)

1) Concepções - Psicopedagogia como prática clínica que cuida das dificuldades de aprendizagem. 
2) Objetivos - utilizar a psicanálise como técnica psicopedagógica de forma a descobrir o sentido inconsciente da dificuldade de aprendizagem e para fazer uma leitura da relação do aluno com suas tarefas e com o psicopedagogo.

3) Tipo de pesquisa - estudo de caso.

4) Autores - Freud, Lacan e Ramain

5) Conclusões - a psicanálise pode contribuir para uma abordagem mais abrangente em psicopedagogia.

05. Psicodrama e Construtivismo como uma Psicopedagogia: estudos com crianças e adolescentes (IPUSP - doutorado - 1994)

1) Concepções - não diz. 
2) Objetivos - analisar a construção do conhecimento por intermédio de aspectos operatórios e individuais e de relações inter individuais.

3) Tipo de pesquisa - empírica.

4) Autores ou Referencial teórico - Construtivismo de Jean Piaget e Psicodrama de Moreno.

5) Conclusões - as performances das crianças nos jogos apontaram a mesma direção das respostas obtidas nas duas aplicações das provas operatórias e no segundo experimento, as intervenções puderam possibilitar a construção do conhecimento.

06. Esquemas de construção numérica elementar e da escrita alfabética em crianças de 5 e 6 anos (doutorado - IPUSP - 1996)

1) Concepções - a autora não faz menção a qual ou quais concepções de psicopedagogia iria utilizar. Mas pelo decorrer do trabalho observa-se que ela utiliza a concepção de psicopedagogia enquanto prática clínica. 
2) Objetivos - descrever "esquemas" (no sentido piagetiano do termo) comuns utilizados pela criança no processo de construção de dois sistemas simbólicos: os números elementares e a escrita alfabética inicial e estabelecer a importância desses esquemas no trabalho com crianças que apresentam dificuldades de aprendizagem.

3) Tipo de pesquisa - pesquisa empírica estudando várias crianças simultaneamente e um estudo de caso.

4) Autores ou Referencial teórico - Epistemologia Genética de Jean Piaget.

5) Conclusões - a escrita alfabética e a notação numérica se constroem através de esquemas que vão se diferenciando progressivamente, mantendo seu núcleo comum: coordenadores cognitivos. Esses esquemas não são totalmente autônomos e podem servir como suporte para um trabalho psicopedagógico que procure fortalecer um domínio simbólico ainda não bem desenvolvido.

01) “Atuação do profissional em psicopedagogia e a formação do psicopedagogo em São Paulo, no período de 1980 a 1990” (Nascimento, M. da G.- 1992). Já aparece na Anped

02. Toda criança é capaz de aprender: uma intervenção psicopedagógica com crianças multirrepetentes (Psicologia da Educação PUC SP - mestrado - 1996)

1) Concepções - baseia-se nas inter-relações entre elementos cognitivos, afetivos e sociais da aprendizagem. 
2) Objetivos - fazer uma proposta pedagógica com estratégias de ação que levem a criança a aprender.

3) Tipo de pesquisa - empírica.

4) Autores ou Referencial teórico - Construtivismo.

5) Conclusões - a intervenção psicopedagógica aponta para a necessidade de se discutir como vem sendo conduzido o processo de ensino-aprendizagem da escrita nas escolas com base no pressuposto que toda criança é capaz de aprender.

03. Letras de música popular: vocabulário, campos conceituais e campos léxico-semânticos como instrumento do ensino de língua (FE - USP - mestrado - 1997)

1) Concepções - não diz.

2) Objetivos - analisar os campos semântico-conceptual e léxico-semântico encontrados nas letras de músicas preferenciais de crianças em idade escolar.

3) Tipo de pesquisa - estudo exploratório por amostragem - empírica.

4) Autores ou Referencial teórico - Psicopedagogia de Alicia Fernandez e Psicologia de Gutierrez, Snyders, Kneller e Pais, Barbosa, Genouvrier, Pottier, Robin. 
5) Conclusões - os temas preferidos pelos alunos devem ser considerados na seleção de conteúdos que a escola realiza. Esses temas devem funcionar para anunciar escolhas mais amadurecidas, que permitam a ampliação do léxico individual dos alunos.

4) "Psicopedagogia inter-ativa : ação psicopedagógica institucional baseada em uma convergência teórica” (Maman, C. de F. de - 1997). Já apareceu na Anped

05. Diálogo entre a psicanálise e a psicopedagogia: sobre a (im)possibilidade de aprender (FE - mestrado - 2000)

1) Concepções - campo teórico-práxico que tem por objeto o sujeito que não aprende.

2) Objetivos - discutir os limites do campo teórico-práxico psicopedagógico diferenciando teorias que consideram o inconsciente das que não consideram.

3) Tipo de pesquisa - teórica.

4) Autores ou Referencial teórico - Jean Piaget, Freud, Lacan, Pain. 
5) Conclusões - a psicanálise e a psicologia genética podem contribuir para a psicopedagogia.

\section{Anexo 2}

